\title{
Geohydrology of the Shallow Aquifer System, Naval Weapons Station Yorktown, Yorktown, Virginia
}

By A.R. Brockman, D.L. Nelms, G.E. Harlow, Jr., and J.J. Gildea

U.S. GEOLOGICAL SURVEY

Water-Resources Investigations Report 97-4188

Prepared in cooperation with the

NAVAL WEAPONS STATION YORKTOWN BASE CIVIL ENGINEER

ENVIRONMENTAL DIRECTORATE

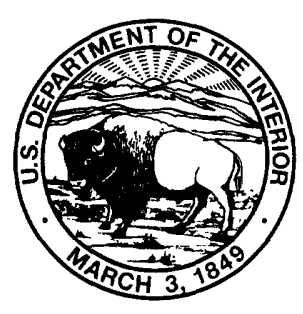




\title{
U.S. DEPARTMENT OF THE INTERIOR BRUCE BABBITT, Secretary
}

\author{
U.S. GEOLOGICAL SURVEY \\ Gordon P. Eaton, Director
}

For additional information write to:

District Chief

U.S. Geological Survey

3600 West Broad Street, Room 606

Richmond, VA 23230-4916
Copies of this report can be purchased from:

U.S. Geological Survey

Information Services

Box 25286

Denver, CO 80225-0046 


\section{CONTENTS}

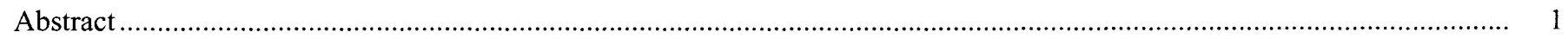

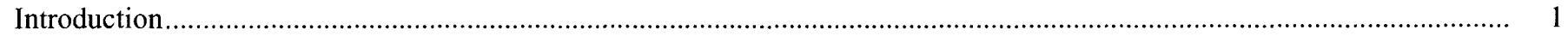

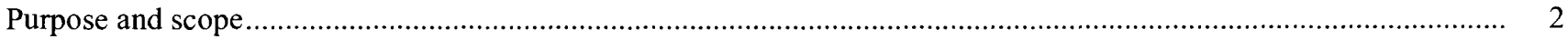

Location of study area and physiographic setting................................................................................................ $\quad 2$

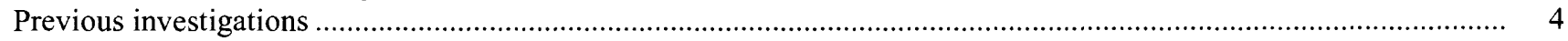

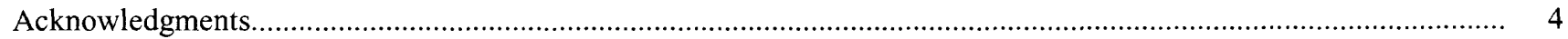

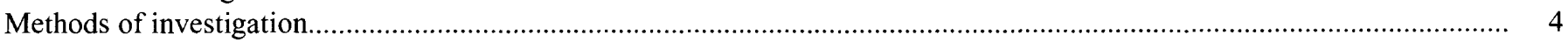

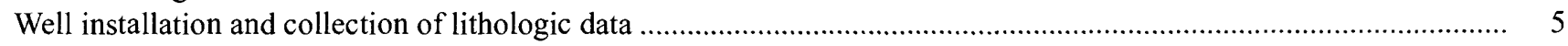

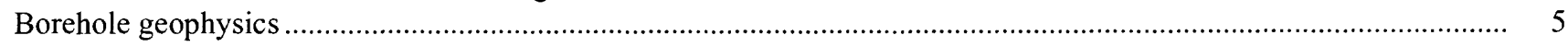

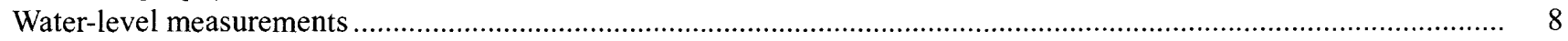

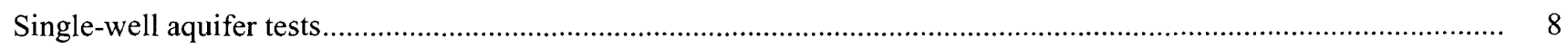

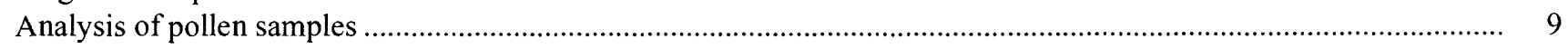

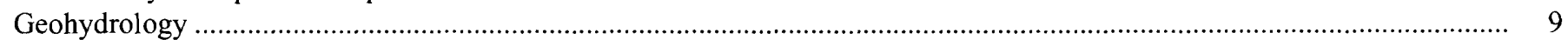

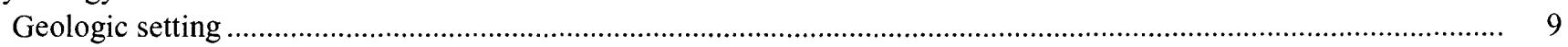

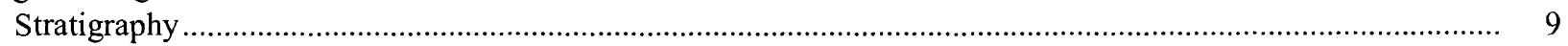

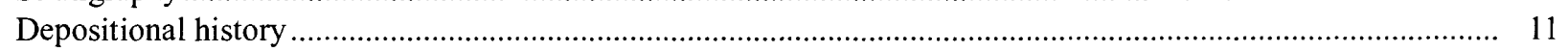

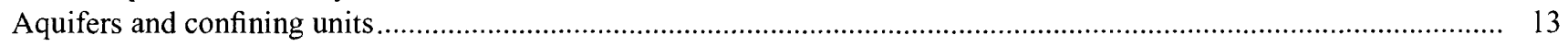

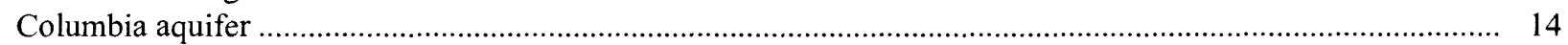

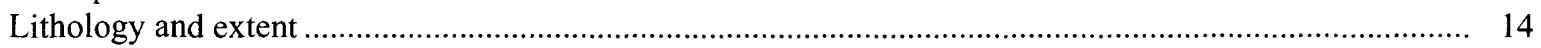

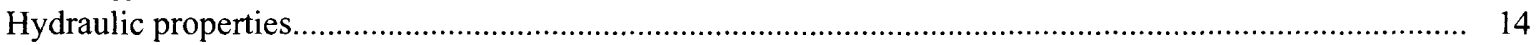

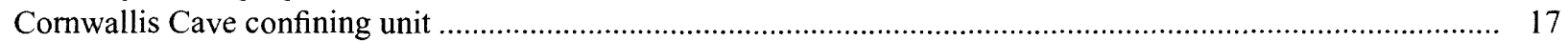

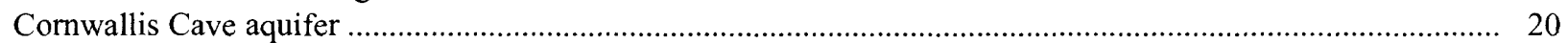

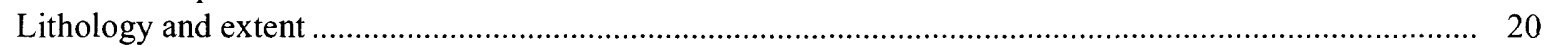

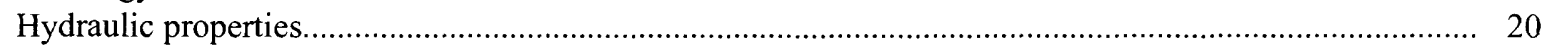

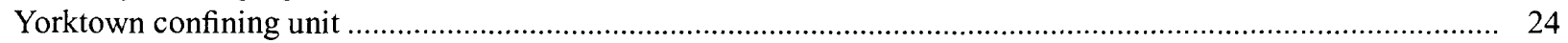

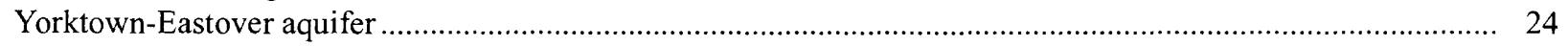

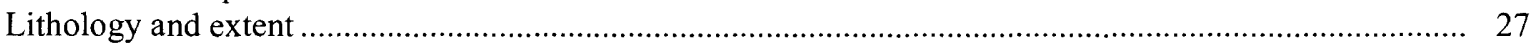

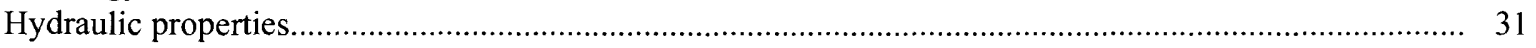

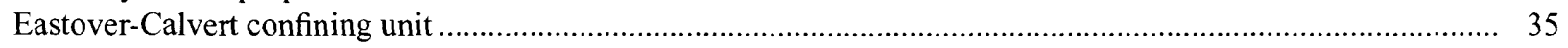

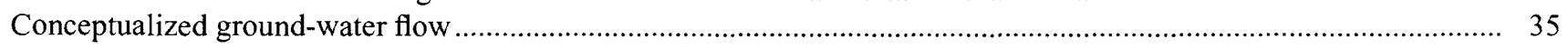

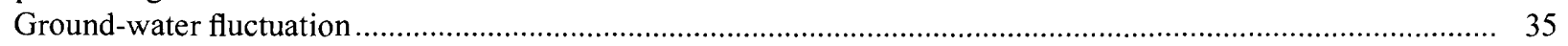

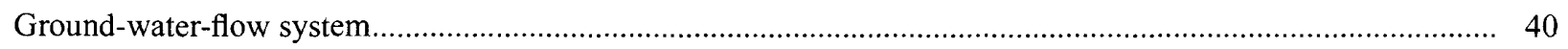

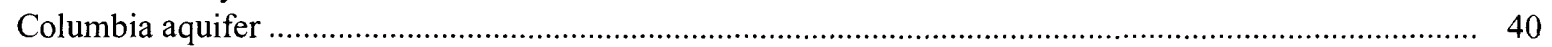

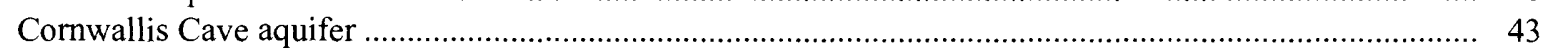

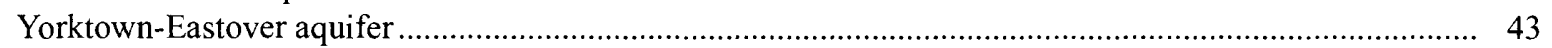

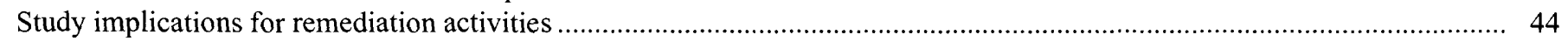

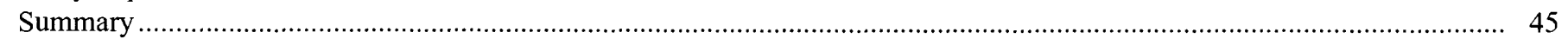

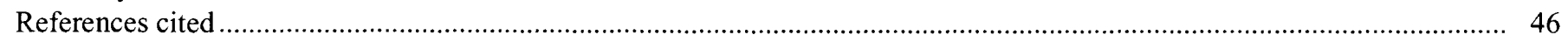

\section{PLATE}

1. Geohydrologic sections and location of terraces and scarps, Naval Weapons Station Yorktown and adjacent area In pocket

\section{FIGURES}

1, 2. Maps showing:

1. Location of the Naval Weapons Station Yorktown (study area) and control wells in the adjacent area ................... 3

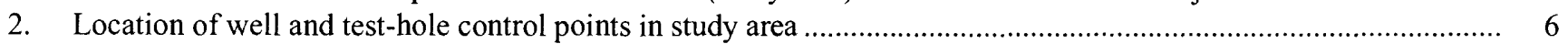




\section{FIGURES-Continued}

3, 4. Diagrams showing standard construction of:

3. Cluster wells

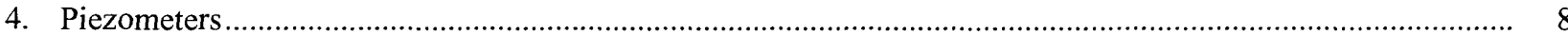

5. Diagram showing relation between the geology and geohydrologic units ....................................................... 10

6-20. Maps showing:

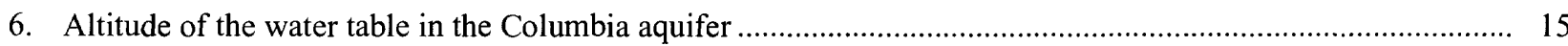

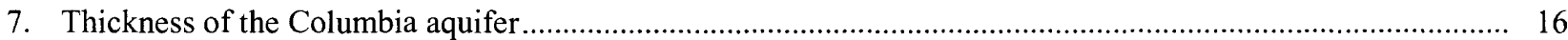

8. Altitude of the top of the Cornwallis Cave confining unit........................................................................ 18

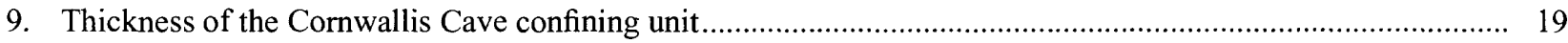

10. Altitude of the top of the confined Cornwallis Cave aquifer ..................................................................... 21

11. Altitude of the water table and potentiometric surface of the Cornwallis Cave aquifer ................................... 22

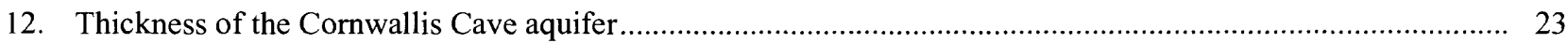

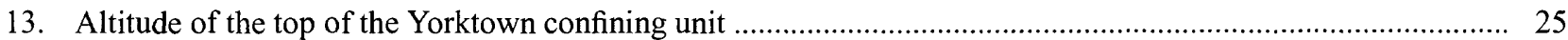

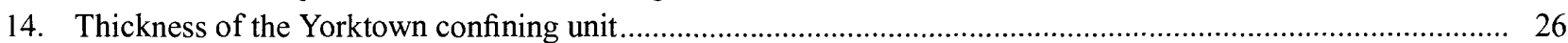

15. Altitude of the top of the confined Yorktown-Eastover aquifer ............................................................... 28

16. Altitude of the water table and potentiometric surface of the Yorktown-Eastover aquifer ............................... 29

17. Altitude of the water table and potentiometric surface of the Yorktown-Eastover aquifer in area

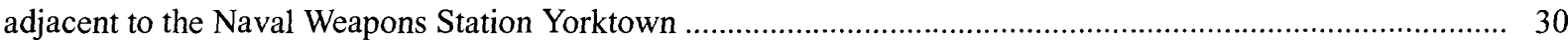

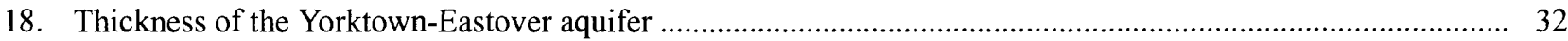

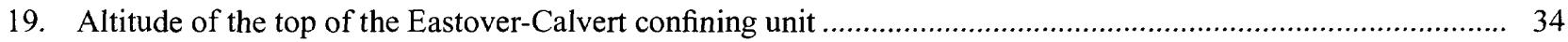

20. Location of U.S. Geological Survey well clusters.............................................................................. 36

21-23. Hydrographs showing water levels and daily mean water temperatures:

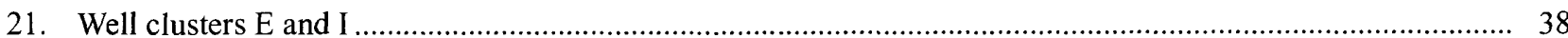

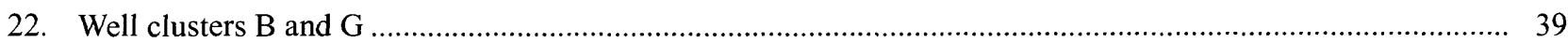

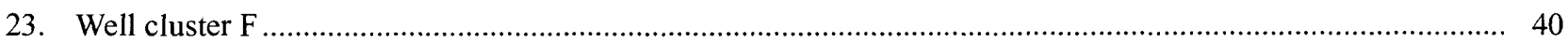

24. Hydrographs showing water levels and response to tidal fluctuations in the York River estuary in wells 58F98, 58F99, and 58G51

25. Geohydrologic section showing conceptualized ground-water flow

\section{TABLES}

1. Record of control wells, control boreholes, and altitudes of the top of the geohydrologic units ....................................... 50

2. Record of geohydrologic-unit thickness and water-level altitude in wells ...................................................................... 56

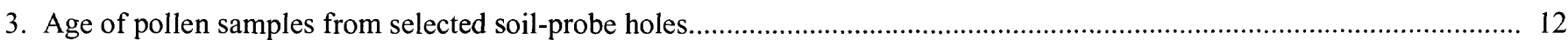

4. Horizontal hydraulic conductivity values for the Columbia aquifer, determined from slug tests ..................................... 14

5. Vertical hydraulic conductivity values for the Columbia aquifer and the underlying Cornwallis Cave confining unit, determined from vertical permeameter tests

6. Horizontal hydraulic conductivity and transmissivity values for the Cornwallis Cave aquifer, determined from slug tests

7. Vertical hydraulic conductivity values for the Cornwallis Cave aquifer and the underlying Yorktown confining unit, determined from vertical permeameter tests.

8. Horizontal hydraulic conductivity and transmissivity values for the Yorktown-Eastover aquifer, determined from slug tests

9. Vertical hydraulic conductivity values for the Yorktown-Eastover aquifer and the underlying Eastover-Calvert confining unit, determined from vertical permeameter tests. 


\begin{tabular}{|c|c|c|}
\hline Multiply & By & To obtain \\
\hline \multicolumn{3}{|c|}{ Length } \\
\hline inch (in.) & 25.4 & millimeter \\
\hline foot $(\mathrm{ft})$ & 0.3048 & meter \\
\hline mile (mi) & 1.609 & kilometer \\
\hline \multicolumn{3}{|c|}{ Area } \\
\hline acre & 4,047 & square meter \\
\hline acre & 0.4047 & hectare \\
\hline \multicolumn{3}{|c|}{ Volume } \\
\hline gallon (gal) & 3.785 & liter \\
\hline gallon (gal) & 0.003785 & cubic meter \\
\hline fluid ounce & 29.573 & milliliter (mL) \\
\hline \multicolumn{3}{|c|}{ Recharge } \\
\hline inch per year (in/yr) & 25.4 & millimeter per year \\
\hline \multicolumn{3}{|c|}{ Flow } \\
\hline foot per day $(\mathrm{ft} / \mathrm{d})$ & 0.3048 & meter per day \\
\hline \multirow[t]{2}{*}{ foot per year (ft/yr) } & 0.3048 & meter per day \\
\hline & Hydraulic conductivity & r \\
\hline foot per day (ft/d) & 0.3048 & meter per day \\
\hline \multicolumn{3}{|c|}{ Transmissivity } \\
\hline foot squared per day $\left(\mathrm{ft}^{2} / \mathrm{d}\right)$ & 0.09290 & meter squared per day \\
\hline \multicolumn{3}{|c|}{ Temperature } \\
\hline degree Celsius $\left({ }^{\circ} \mathrm{C}\right)$ & ${ }^{\circ} \mathrm{C}=\left({ }^{\circ} \mathrm{F}-32\right) / 1.8$ & degrees Fahreheit \\
\hline
\end{tabular}

Hydraulic conductivity and transmissivity: In this report, hydraulic conductivity is reported in feet per day $(\mathrm{ft} / \mathrm{d})$, a mathematical reduction of the unit cubic foot per day per square foot $\left[\left(\mathrm{ft}^{3} / \mathrm{d}\right) / \mathrm{ft}^{2}\right]$. Transmissivity is reported in feet square per day $\left(\mathrm{ft}^{2} / \mathrm{d}\right)$, a mathematical reduction of the unit cubic feet per day per square foot times feet of aquifer thickness $\left(\left[\left(\mathrm{ft}^{3} / \mathrm{d}\right) / \mathrm{ft}^{2}\right] \mathrm{ft}\right)$.

Vertical datum: In this report, "sea level" refers to the National Geodetic Vertical Datum of 1929 - a geodetic datum derived from a general adjustment of the first-order level nets of the United States and Canada, formerly called Sea Level Datum of 1929. 


\title{
Geohydrology of the Shallow Aquifer System, Naval Weapons Station Yorktown, Yorktown, Virginia
}

\author{
By Allen R. Brockman, David L. Nelms, George E. Harlow, Jr., and Jason J. Gildea
}

\section{Abstract}

This report presents the results of a study by the U.S. Geological Survey (USGS), in cooperation with the Naval Weapons Station Yorktown, Base Civil Engineer, Environmental Directorate, to describe the geohydrology of the shallow aquifer system at the Station and in the adjacent area. Twelve test holes and 28 wells at 7 well clusters were installed across the Station in 1995, and 47 soil probe holes and 6 piezometers were installed in 1996. Geophysical logs, x-ray mineralogy and vertical hydraulic conductivities from Shelby-tube samples, horizontal hydraulic conductivities from single-well tests, water-level-fluctuation graphs, water-level maps, and pollen analyses were used to define the geohydrology of the study area.

The geohydrology consists of six units including the: (1) Columbia aquifer, (2) Cornwallis Cave confining unit, (3) Cornwallis Cave aquifer, (4) Yorktown confining unit, (5) Yorktown-Eastover aquifer, and (6) Eastover-Calvert confining unit. The geohydrologic units are in sediments of Miocene to Holocene age. Horizontal hydraulic conductivities in the aquifers range from 0.004 to $9 \mathrm{ft} / \mathrm{d}$ (feet per day). Vertical hydraulic conductivities in the aquifers and the two upper thin ( 8 to $14 \mathrm{ft}$ ), leaky confining units are comparable and range from $10^{-5}$ to $10^{-1} \mathrm{ft} / \mathrm{d}$. The top of the thick ( 140 to $166 \mathrm{ft}$ ) basal Eastover-Calvert confining unit is from 40 to more than $80 \mathrm{ft}$ below sea level and has vertical hydraulic conductivities of $10^{-6}$ to $10^{-4} \mathrm{ft} / \mathrm{d}$.

A conceptualization of ground-water flow was developed from the collected geohydrologic data. Water flows downward from the Columbia aquifer in the recharge areas through the Cornwallis Cave confining unit to the Cornwallis Cave and Yorktown-Eastover aquifers. Water flows laterally, downward, and in some instances, returns upward through the lower two aquifers to discharge at seeps, springs, streams, and estuaries.
Ground-water divides across the south-central part of the Station in each of the lower aquifers separate water flowing north toward the York River estuary from that flowing south toward the James River estuary.

\section{INTRODUCTION}

The U.S. Geological Survey (USGS), in cooperation with the Naval Weapons Station Yorktown, Yorktown, Va., began a study of the shallow aquifer system at the 10,624-acre installation in 1995. The Station is in a geologically unique area where slumping and dissolution of calcareous sediments has resulted in complex geomorphic features. Human development has been influenced by an evolving landscape and the availability of ground water (Johnson and others, 1982; Brockman and Richardson, 1992; and Johnson and others, 1993).

The Naval Weapons Station tract was known to the native Americans as the "Chischiak" region (Hagemann, 1988). During colonial times, the land was parceled out among the West, Lee, Digges, and Felgate families, and the remains of some of their dwellings are preserved both at the Station and adjacent Colonial National Historical Park. One of the first recorded environmental fatalities at what was to become the Naval Weapons Station Yorktown installation occurred during the colonial period when Governor Digges' daughter drowned in quicksand in one of the collapsed valleys (Clingan, 1961).

During the American Revolution, General Washington entrenched his forces along the narrow, collapsed shell-hash ravines to tighten his military lines around Lord Cornwallis' forces to the east of the Station (Mitchell, 1962, p. 206). Washington's headquarters were near a spring in Colonial National Historical Park that now bears Washington's name (Charles Rafkind, Colonial National Historical Park, oral commun., 1995). During 
the Civil War, Confederate troops built dams across many of these same drainages in the vicinity of the Station to flood the narrow collapsed valleys and thereby created deep moats to defend against the advancing Union army (Foote, 1986, p. 399).

With the arrival of the 20th century and World War 1 , agriculture was replaced by industry when the Station was established in 1918 as the "Navy Mine Depot" to manufacture mines for use in the North Sea. During World War 1I, production of ordnance and research and development of high explosives began at the Station (Naval Weapons Station, 1993). Ordnance production and research continues today at a tenant facility at the Station, but the last major ordnance plant ceased operations in 1994. Today, the Station is primarily involved in the maintenance, storage, and distribution of ordnance for the Atlantic Fleet.

The Environmental Directorate at the Naval Weapons Station Yorktown is responsible for the management of the environmental resources of the Station and identification and remediation of environmental contamination that results from Station activities. On October 15, 1992, the Station was placed on the National Priorities List as a Comprehensive Environmental Response, Compensation, and Liability Act (CERCLA) site by the U.S. Environmental Protection Agency (USEPA) (U.S.

Environmental Protection Agency Region IIl and others, 1994). The USGS study of the shallow aquifer system was conducted to provide information for environmental and public works activities at the Station.

\section{Purpose and Scope}

The purpose of this report is to describe and characterize the geohydrologic framework of the shallow aquifer system at the Station. This report presents the results of a 2-year study of the shallow aquifer system. Data generated during the investigation were submitted to the Station on September 26, 1996 (Allen Brockman, U.S. Geological Survey, unpub. data, 1996).

The report (1) defines the geohydrologic framework for the shallow aquifer system, (2) determines the hydraulic properties of the geohydrologic units, and (3) presents a conceptualization of the ground-water-flow system. Lithologic and water-level data were used to define the geohydrologic framework. Lithologic data were obtained from (1) test-hole and well drilling, (2) borehole geophysical logging, (3) foundation borings, and (4) soil-probe borings. Slug tests provided data for evaluating horizontal hydraulic conductivities, while vertical permeameter tests of Shelby-tube cores provided vertical hydraulic conductivity data. Pollen samples were analyzed to identify the location of recent channel deposits across the Station. Synoptic and continuous waterlevel measurements from the Station-wide observation well network were used in conjunction with the defined framework to depict ground-water flow.

\section{Location of Study Area and Physiographic Setting}

The study area consists of the Naval Weapons Station Yorktown only, and is located in central York County and part of James City County and Newport News City, Va., between the James and York River estuaries of Chesapeake Bay (fig. 1). The Station is within the Atlantic Coastal Plain Physiographic Province (fig. 1). The Coastal Plain, which consists primarily of unconsolidated sediments, extends from the Atlantic Ocean westward to the Fall Line, a distance of 75 to $90 \mathrm{mi}$. The Fall Line represents the boundary between the Coastal Plain and the Piedmont Physiographic Province. The topography of the Coastal Plain is divided into a series of terraces of different elevations deposited during rising and falling sea level throughout recent geologic history. These terraces are bounded by scarps cut by shoreline erosion (Johnson and others, 1993).

The Naval Weapons Station study area and the adjacent area is divided into four terraces and three scarps as shown on plate 1 (scarp map modified from Mixon and others, 1989; Johnson and others, 1993). The Lackey Plain (Johnson, 1972) is the highest terrace in the study area and is highest in altitude between 90 and 100 $\mathrm{ft}$ above sea level and lowest in altitude at $70 \mathrm{ft}$ above sea level along the crests of the bounding scarps.

The Lackey Plain is bounded on the south, east, and north by the Kingsmill, Lee Hall, and Camp Peary scarps, respectively (Johnson and others, 1993). Along the York River estuary at the base of the Camp Peary scarp is the Croaker flat, a low-lying terrace. Along the James River estuary at the base of the Kingsmill scarp is the Huntington flat, another low-lying terrace. The Croaker flat and the Huntington flat are highest in altitude at $45 \mathrm{ft}$ above sea level along their respective scarps and lowest in altitude at nearly sea level along the coastline (Bick and Coch, 1969). At the base of the Lee Hall scarp is the Grafton Plain. The Grafton Plain is highest in altitude at $60 \mathrm{ft}$ above sea level along the scarp and 


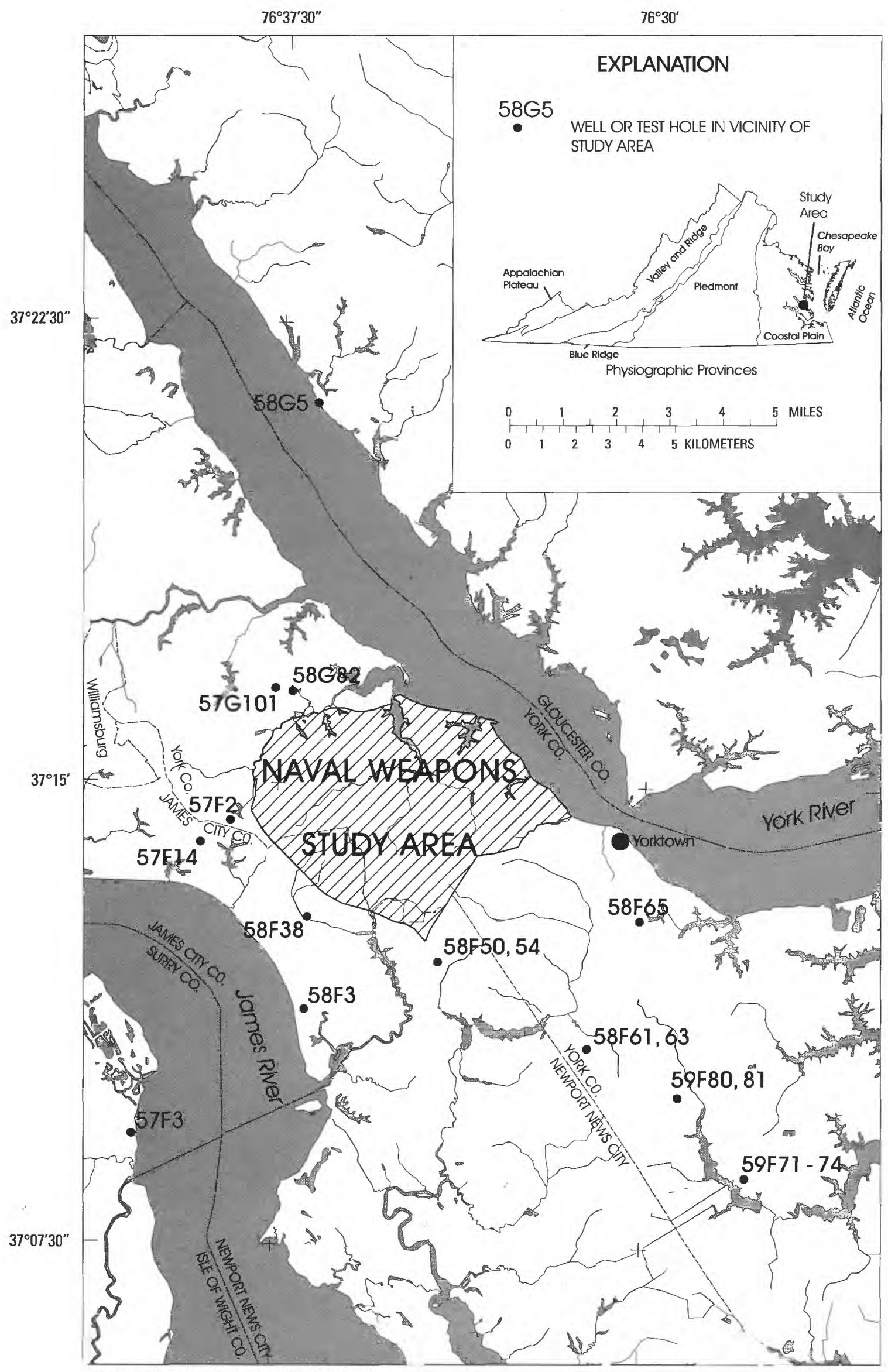

Base from U. S. Geological Survey 1:100,000

Figure 1. Location of the Naval Weapons Station Yorktown (study area) and control wells in the adjacent area. 
lowest in altitude at $48 \mathrm{ft}$ above sea level east of the Station (Johnson, 1972). The study area extends from the Lackey Plain to the Croaker flat (terrace and scarp inset, pl. 1).

\section{Previous Investigations}

Many studies have been done that define the regional geohydrologic setting in the Coastal Plain of Virginia, and some studies have focused on the YorkJames Peninsula where the Station is located. Cederstrom (1957) did the first comprehensive geohydrologic study of the peninsula and provided well-construction records, drillers' logs, and ground-water-quality data. The Virginia Department of Environmental Quality, formerly the Virginia State Water Control Board (1973), described the geohydrology and water quality of the "upper and principal artesian systems" in the same area of the peninsula investigated by Cederstrom. By correlating electric geophysical logs collected throughout the Virginia Coastal Plain, Meng and Harsh (1988) divided the geohydrologic framework of the Coastal Plain into nine regional aquifers. Laczniak and Meng (1988) conceptualized the ground-water-flow system and used a finite-difference ground-water-flow model to simulate the ground-water flow under the York-James Peninsula. Brockman and Richardson (1992) locally refined the York County part of the shallow geohydrologic framework originally described in Meng and Harsh (1988) and modified in Laczniak and Meng (1988). The USGS maintains records of selected water-level and (or) geophysical-log data from wells outside the study area shown in figure 1 and catalogued in tables 1 and 2 (located at the end of this report).

Geohydrologic studies at the Station have focused on the potential for surface-water and (or) ground-water contamination posed by hazardous-waste sites. During an initial assessment study (Johnson and Associates, Inc. and $\mathrm{CH} 2 \mathrm{M}$ Hill, 1984), 15 potential environmental contamination sites were identified at the Station. Drillers' $\operatorname{logs}$, water-level, water quality, and slug-test data were collected from 64 shallow wells (less than $100 \mathrm{ft}$ ) throughout the Station during subsequent confirmation and remediation investigation studies (Dames and Moore, 1986, 1988; Baker Environmental, Inc., and Roy F. Weston, Inc., 1993; Baker Environmental, Inc., 1995) as part of the Environmental Directorate's Installation Restoration Program (IRP). Additional detailed studies of the IRP sites are in progress.
A nearby geohydrologic study was conducted for the USEPA Region III at the Commonwealth of Virginia Emergency Fuel Storage Facility (CVEFSF), a 460 acre site, formerly part of the Navy's Cheatham Annex (Engineering-Science, Inc., 1994). The CVEFSF study was conducted in a setting similar to much of the Station, less than half a mile from the northwestern Station boundary. Drillers' logs, water-level, water quality, slugtest, and aquifer-test data were collected at the CVEFSF from 48 shallow wells (less than $100 \mathrm{ft}$ ).

\section{Acknowledgments}

Mr. Jeffrey Harlow of the Naval Weapons Station Yorktown Environmental Directorate was of great assistance in facilitating this study. Ms. Carolyn Neill, Mr. Glenn Markwith, and Mr. Bernard Setterholm, also of the Directorate, were of great assistance. Jeffrey Krempasky, a former student-hydrologist trainee with the USGS, devoted much time and field work to the study. Mr. Richard Hoff of Baker Environmental, Inc., and Mr. Richard Stryker, Atlantic Division, Naval Facilities Engineering Command, provided valuable assistance and comments during the course of the study. The Naval Weapons Station Yorktown Review Advisory Board provided a necessary forum for the review of data generated during the study. Mr. T. Scott Bruce, of the Virginia Department of Environmental Quality, and Dr. C. Richard Berquist, Jr., of the Virginia Division of Mineral Resources provided additional data and stratigraphic information for the study. Dr. Jerre H. Johnson of William and Mary College provided stratigraphic information and analysis. The U.S. Army Corps of Engineers, Mobile, Ala., District installed the observation wells, and the U.S. Army Corps of Engineers, Ohio River Division Laboratory, analyzed the Shelby-tube cores for this study. Dr. Grace S. Brush of the Johns Hopkins University conducted the pollen analysis for this study.

\section{METHODS OF INVESTIGATION}

Methods used to investigate the geohydrology of the Station include: well installation and sediment collection, soil probing, borehole geophysics, water-level measurements, single-well aquifer tests, and pollen sample analysis. 


\section{Well Installation and Collection of Lithologic Data}

The USGS installed 12 test holes for geophysical logging, 28 wells at 7 well clusters, 47 soil probe holes, and 6 piezometers across the Station between July 1995 and December 1996 to define site geohydrology. Well, test hole, soil probe hole, and piezometer placement was planned to yield a maximum of geohydrologic information while avoiding known hazardous waste sites. Well clusters and test holes were located to maximize crosssectional views of the Station's geohydrology and to investigate areas adjacent to estuaries where confining units are commonly breached. Soil probe holes and piezometers were located to provide supplementary data in areas between the well clusters and test holes.

The USGS test holes, wells, soil probe holes, and piezometers range from 13 to $282 \mathrm{ft}$ in depth, and their locations and other data points from the Station are shown in figure 2 and catalogued in tables 1 and 2 (at the end of this report). The wells were screened at distinct depth increments in shelly or sandy sediments to determine the number and extent of permeable water-bearing zones (potential aquifers) within the interval of interest. All of the cluster wells and test holes were drilled by the hydraulic-rotary method. Cuttings and split-spoon samples were collected from each well borehole for detailed lithologic description. Shelby-tube samples were collected for vertical hydraulic and mineralogic analyses; 67 Shelby-tube samples from the USGS drilling investigation were analyzed by $x$-ray diffraction and falling-head permeameter tests (U.S. Army Corps of Engineers, Ohio River Division Laboratory, unpub. data., 1996).

Well construction and screen length depended on well depth and aquifer thickness. Test wells were drilled before well installation to identify potential geohydrologic contacts. Bentonite grout was tremied in from the bottom to fill and abandon each test well after geophysical logging was completed. Well clusters were constructed as shown in figure 3 . All wells are constructed of 4-in.-inside-diameter schedule 40 flush-threaded polyvinyl chloride (PVC) casing and screens. Screen length ranges from $5 \mathrm{ft}$ for the shallowest two wells to $10 \mathrm{ft}$ for the deepest two wells in each four-well cluster. Screenslot size is $0.01 \mathrm{in}$. for all the wells. Piezometers were constructed as shown in figure 4. All piezometers were constructed of 0.75 -in.-inside-diameter galvanized-iron pipe and screen. Four of the piezometer screens (57F33, $57 \mathrm{~F} 34,57 \mathrm{~F} 35$, and $58 \mathrm{~F} 154$ ) each consist of a single $0.5 \mathrm{ft}$ length of perforated pipe and the other two piezometer screens (58F158 and 58F159) consist of a single $0.5 \mathrm{ft}$ length of a slotted pipe.

The annulus of each well was filled with three materials: (1) filter sand, (2) bentonite pellets, and (3) bentonite grout. Initially, medium filter sand was piped to the bottom of the annulus of each well and added until the sand pack was level with the top of the potential aquifer. Next, 0.25 -in. bentonite pellets were piped to the top of the filter sand to seal off the sand pack and the potential aquifer. Finally, bentonite grout was piped to the top of the bentonite pellets and up through the annular space to land surface to complete the final sealing of the well. A concrete pad and a lockable steel protector were constructed at land surface to complete each well.

Galvanized-iron pipe for each piezometer was installed using a soil probe. A steel point was affixed to the bottom of each piezometer before installation to prevent sediment from entering from the bottom of each piezometer string. The borehole at each piezometer was bored by advancing galvanized pipe into the ground with the soil-probe hydraulic jack. Thus, no open annular space remained around each piezometer following installation. The natural swelling of clays and clayey sediment around the piezometer pipes eliminated any need for additional annular sealing. The piezometers were capped and a concrete pad was constructed at land surface for completion.

A soil probe was used to collect additional lithologic data from across the Station in the fall 1996 to supplement data collected during the earlier drilling phase. The soil probe is a hydraulically powered coring device used to advance 2- to 0.75-in. diameter steel or galvanized pipe into the subsurface to collect soil cores or install piezometers. The soil-probe unit used at the Station was mounted on the back of a small utility truck, and it could be operated in either a direct-static-force or percussion-hammer mode. Maximum potential penetration depth in the unconsolidated sediments was more than $100 \mathrm{ft}$ with the soil probe at most Station locations.

\section{Borehole Geophysics}

Borehole geophysics was used both to define a preliminary geohydrologic framework and to guide screen placement at the Station. Natural-gamma and electromagnetic-conductivity geophysical logs were recorded at 12 USGS test wells from across the Station. 


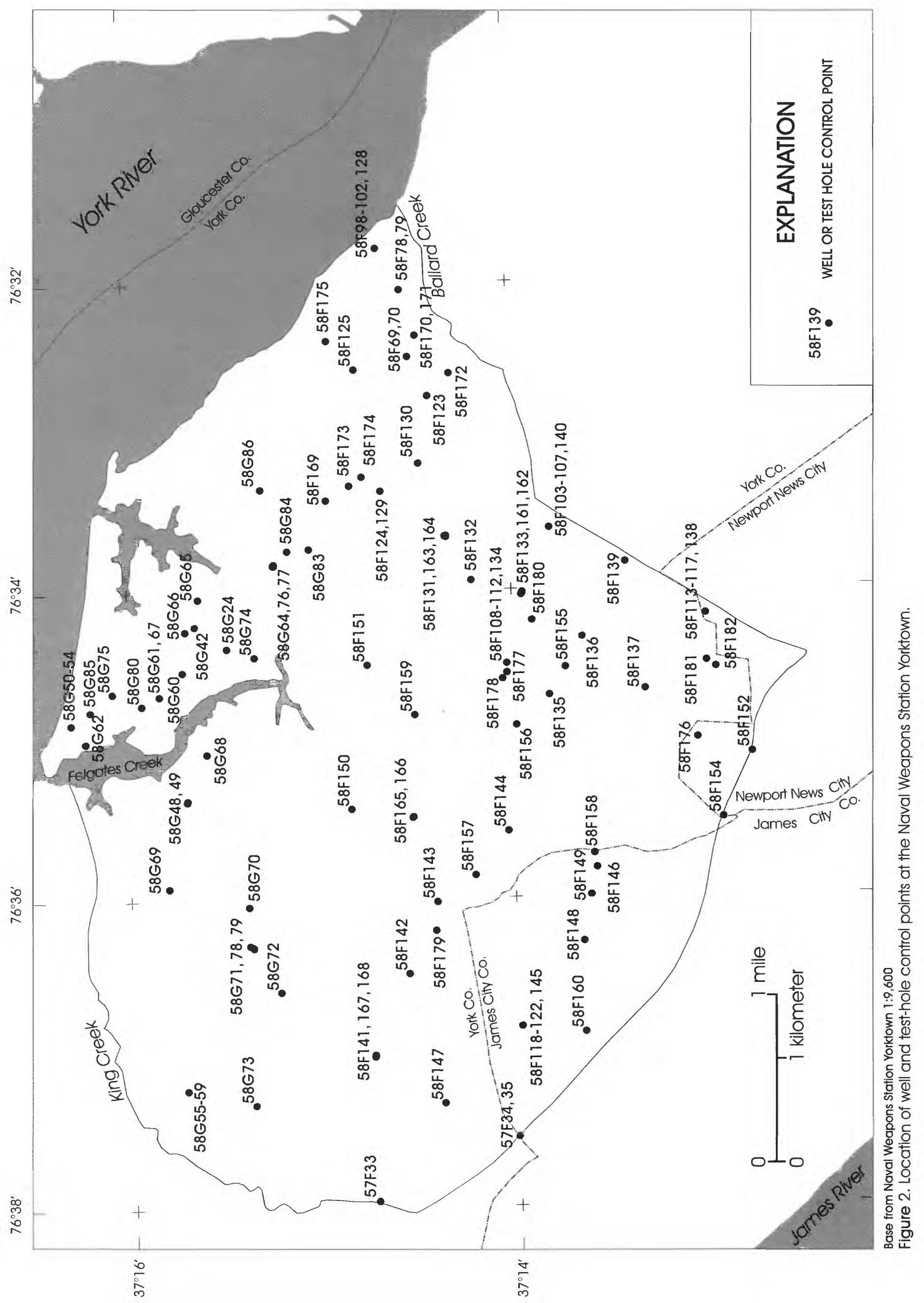




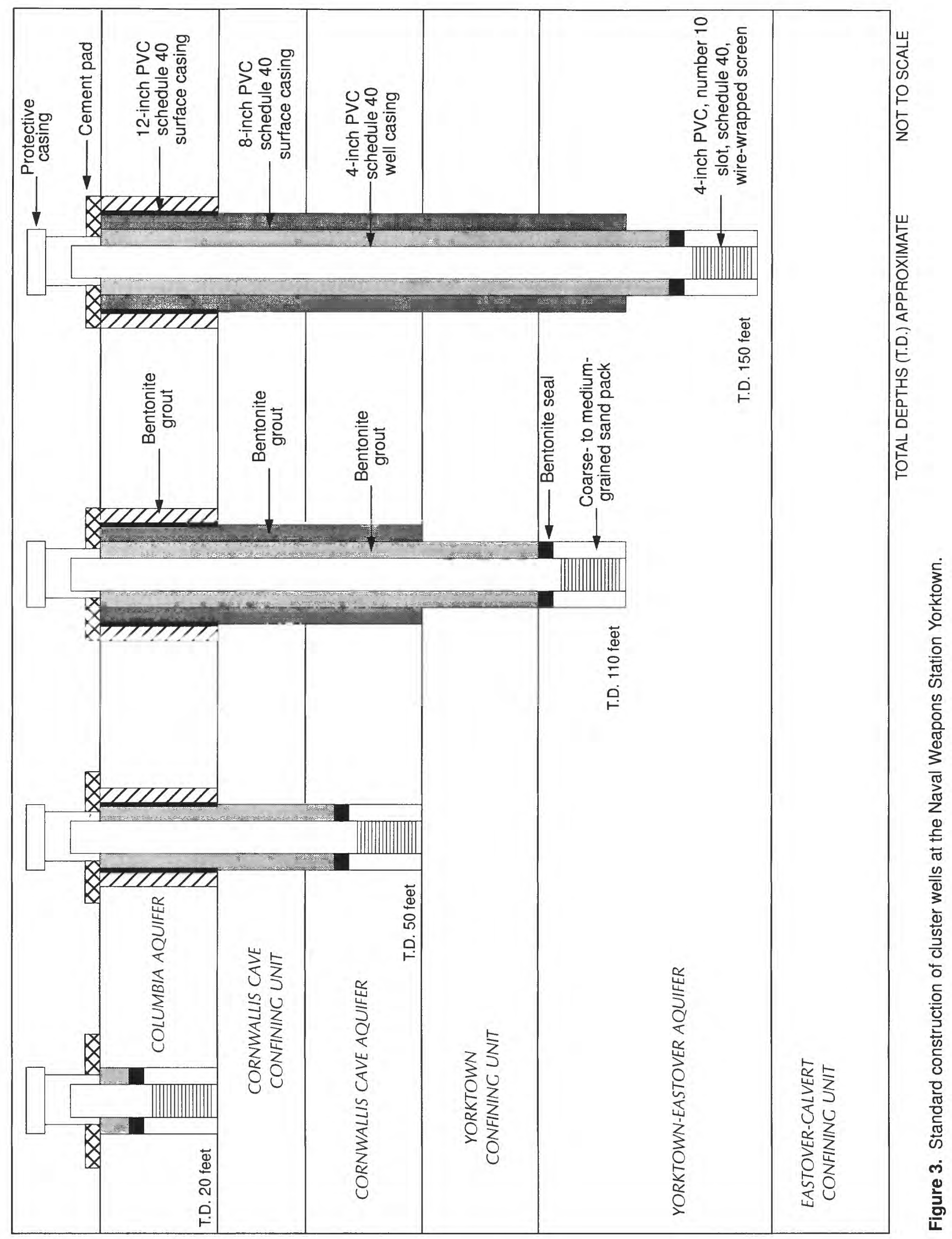




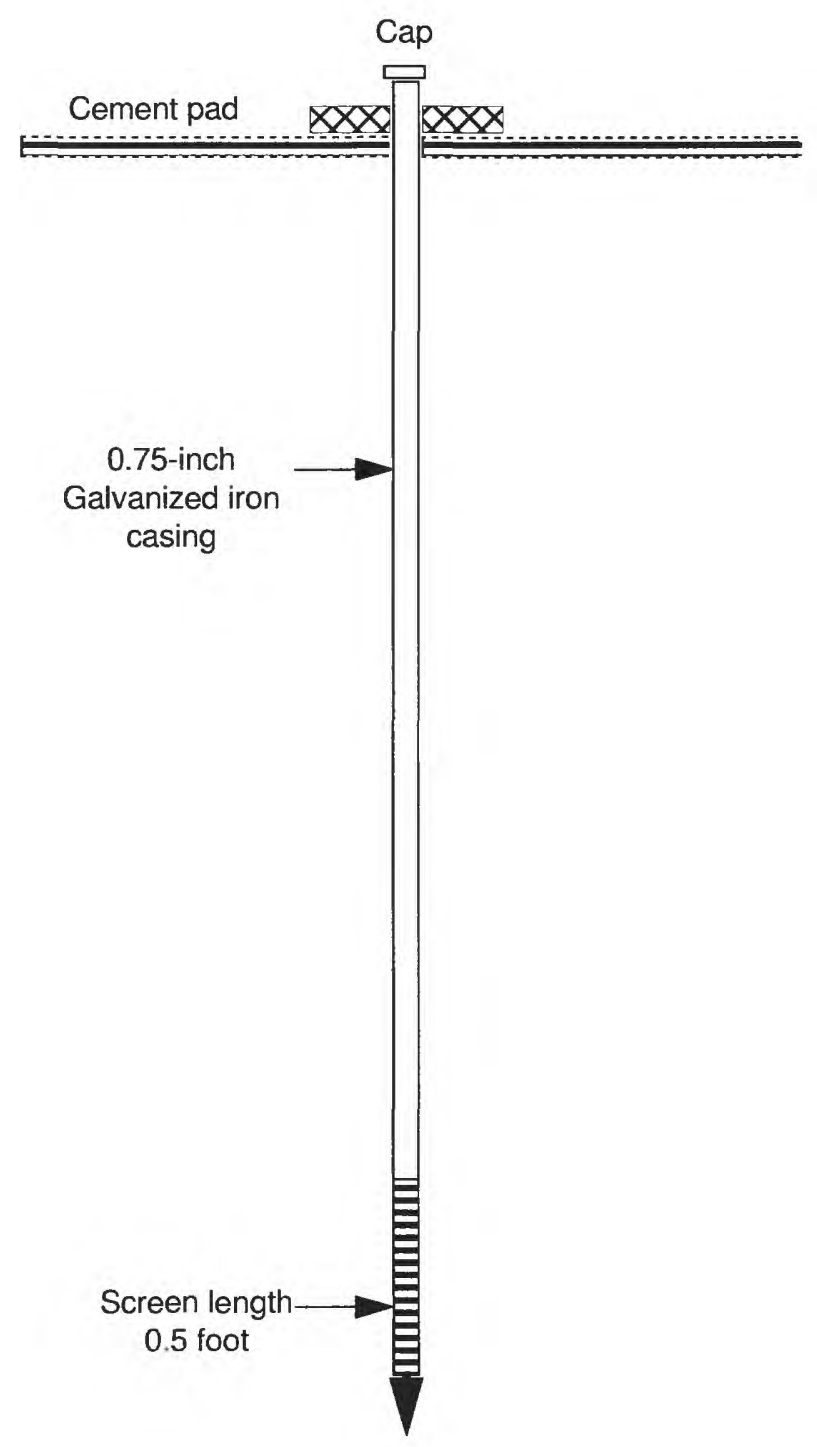

NOT TO SCALE

Figure 4. Standard construction of piezometers at the Naval Weapons Station Yorktown.

Interpretations from these geophysical data were augmented with additional lithologic and hydrologic data collected later in the investigation.

Geophysical logs from the test wells correlative with other geophysical logs from the vicinity of the Station were used to compile geohydrologic sections follow- ing the approach detailed in Meng and Harsh (1988). Electric geophysical logs published in the earlier York County study (Brockman and Richardson, 1992) are published again in this report to extend geohydrologic sections in the area adjacent to the Station study area.

\section{Water-Level Measurements}

Water-level data were used to provide information on seasonal and tidal fluctuations and vertical head gradients between aquifers and to verify the geohydrologic framework established from borehole geophysics. Water levels in the cluster wells were measured at 15-minute intervals from early 1996 (after well development at each cluster) to July 1997 by use of water-level-recording devices consisting of a pressure transducer and digital data recorder in each well. In the seven USGS well clusters, 24 wells were equipped with water-level recorders. Recorded water levels were verified with periodic chalked-steel-tape measurements. Additional electrictape water-level measurements were recorded monthly at an extended network of other observation wells from May 1996 to July 1997 to document seasonal variation at these wells.

\section{Single-Well Aquifer Tests}

Slug tests were conducted at the USGS wells in May 1996 to determine horizontal hydraulic conductivity in the aquifers. Slug tests were not conducted at wells $58 \mathrm{~F} 101,58 \mathrm{~F} 111,58 \mathrm{G} 53$, and 58G58 because the wells were dry throughout the period of the investigation. Horizontal hydraulic conductivities were calculated from slug tests in 24 of the 28 wells. Additional horizontal conductivities determined by Baker Environmental, Inc., and Roy F. Weston, Inc., (1993) from other selected wells were included to supplement the USGS data set.

Slug tests provide an estimate of the horizontal hydraulic conductivity (Lohman, 1979), and they are useful where conventional aquifer tests cannot be done within funding constraints. The slug used at the Station consisted of a 4-ft length of stainless-steel pipe filled with sand and sealed at both ends. The slug displaced approximately 1.03 gal of water, resulting in a maximum vertical change of $1.6 \mathrm{ft}$ in water level in a 4-in. well. A pressure transducer and data logger were used to record the water-level response to the introduction of the slug as well as to its subsequent removal. The results were 
analyzed to determine horizontal hydraulic conductivity by methods detailed in Bouwer (1989) for unconfined aquifers and in Cooper, Bredehoeft, and Papadopulos (1967) for confined aquifers.

\section{Analysis of Pollen Samples}

Pollen analysis was used to identify the extent of sediments that have been eroded and redeposited by the York River and tributary streams in the northeastern area of the Station during approximately the last one million years. These sediments were recognized from distinctive plant debris within clays and from the presence of very coarse grained units that do not easily correlate to the geohydrologic units in the western and southern areas of the Station. The pollen analysis aided in the geohydrologic interpretation of the northeastern area of the Station.

Pollen samples were collected using a soil probe during the fall 1996. Of the 12 samples collected from different depths in soil-probe holes scattered across the northeastern area of the Station, 10 samples consisted of sand, clay, or shell hash. The remaining two samples (clay) were collected from separate soil probe holes in the southern and western areas of the Station. Each of the 12 samples was collected in a 2 - $\mathrm{ft}$ by 1 -in. diameter acetate liner using a hardened-steel soil-probe sampler, and each was sealed immediately following retrieval from the soil probe hole. The acetate encased samples were cut into approximately 5 -in. sections at the USGS preparation facility and resealed before shipment to the pollen lab in January 1997.

Pollen analyses on the samples were conducted at the Department of Geography and Environmental Engineering at the Johns Hopkins University. To extract pollen from the sediment, a specific volume of sediment was washed first in hydrochloric and then in hydrofluoric acid and acetylzed to remove carbonates, silicates, and organic material. The residue was washed in acetic acid, distilled water, and alcohol and then isolated in tertiary butyl alcohol. Aliquots $(0.2 \mathrm{~mL})$ were mounted in silicone oil on glass slides and analyzed under $400 \times$ (magnification). All pollen grains on the slide were identified and counted to determine sample age. (Grace Brush, Johns Hopkins University, written commun., 1997).

\section{GEOHYDROLOGY}

The Naval Weapons Station Yorktown is in Virginia's Coastal Plain Physiographic Province. The Coastal Plain Physiographic Province generally consists of layered, unconsolidated, sedimentary deposits that thicken and slope seaward. The deposits consist of interbedded clay, silt, sand, and gravel and variable amounts of shell material that form a system of layered aquifers and confining units.

\section{Geologic Setting}

The stratigraphy and depositional history of the sediments of the shallow aquifer system at the Station and adjacent areas of the York-James Peninsula are described in Brockman and Richardson (1992). The following geologic description of the immediate Naval Weapons Station Yorktown vicinity is drawn from that report.

\section{Stratigraphy}

The stratigraphy of the shallow aquifer system at the Station consists of nine formally named geologic formations, which range in age from early Miocene to late Pleistocene, and undifferentiated alluvial and marsh deposits of Holocene age (fig. 5). Two of these formations are subdivided to form two to four geologic members. Distinct geohydrologic units at the Station correlate to one or more of the geologic members or formations, as described in the section "aquifers and confining units." All formations and members of Miocene or Pliocene age, except the Sedley and Bacons Castle Formations, are in the Chesapeake Group (Ward and Blackwelder, 1980; Johnson and others, 1982). The Sedley and younger formations are not included in a specific group (fig. 5).

The Miocene Calvert Formation contains interbedded shelly and sandy clay, silty clay, and diatomaceous clay (Ward, 1984; Meng and Harsh, 1988). The sandy and silty clay interbedded sequences that compose the Calvert Formation are the oldest geologic units correlated with the geohydrologic units for the Naval Weapons Station Yorktown study.

The Miocene St. Marys Formation unconformably overlies the Calvert Formation (Ward, 1984; Meng and Harsh, 1988) at the Station. The St. Marys Formation contains silty and sandy clay with shells. 


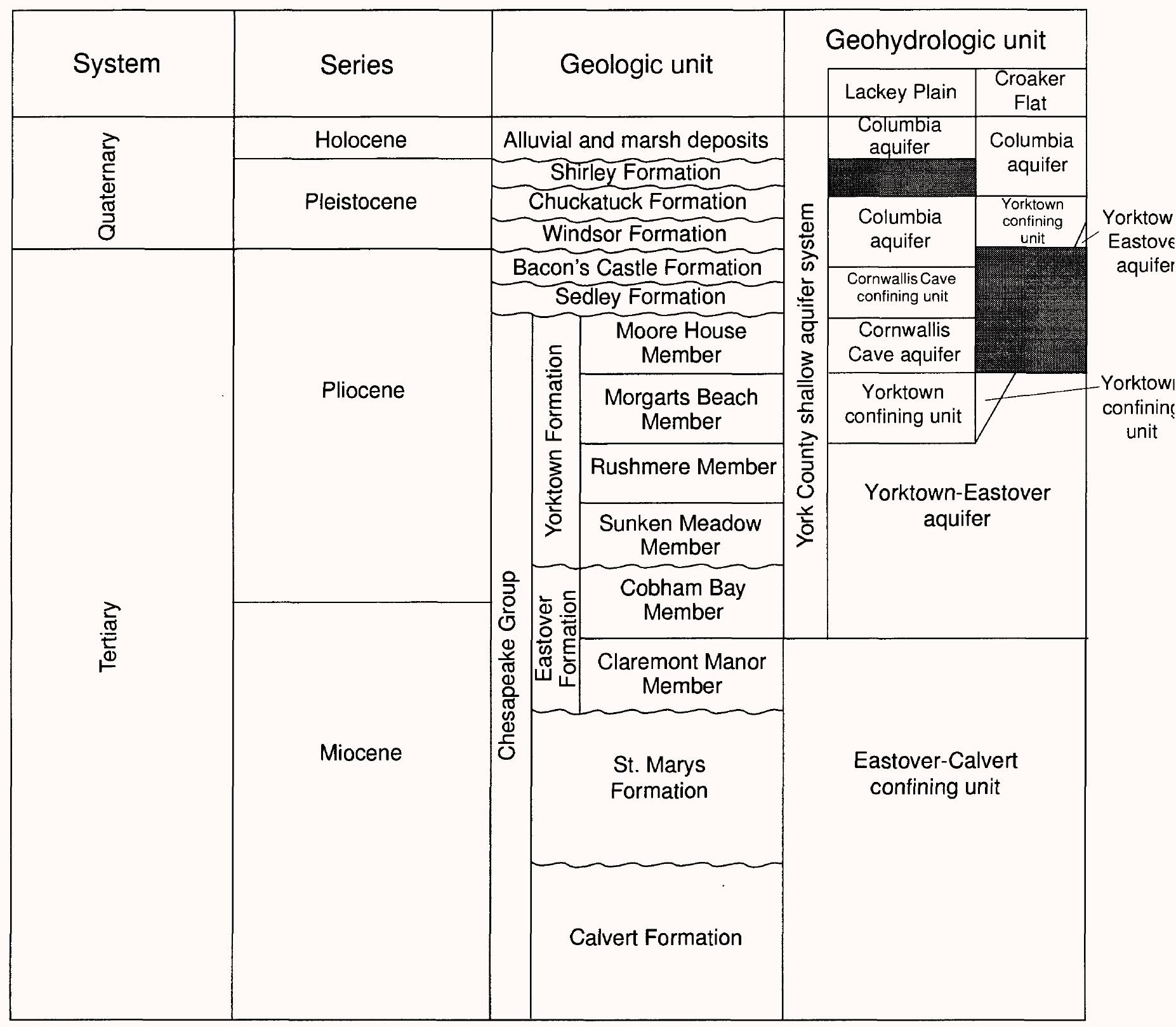

Figure 5. Relation between the geology and geohydrologic units at the Naval Weapons Station Yorktown.

Above a second unconformity at the top of the St. Marys Formation is the upper Miocene Eastover Formation. The Eastover Formation is divided into two members (Ward and Blackwelder, 1980). The Claremont Manor Member contains clayey silt and silty to sandy clay. The Cobham Bay Member is a slightly coarser grained unit, containing very fine- to fine-grained sand, silty sand, silt, or sandy clay at the Station.
The lower Pliocene Yorktown Formation overlies a third unconformity, at the top of the Eastover Formation. In the southern part of the Station, a silty clay or clayey silt, possibly part of the Eastover Formation (C. Richard Berquist, Virginia Division of Mineral Resources, oral commun., 1997) is present locally along the EastoverYorktown unconformity. The Yorktown Formation is divided into four members: (1) the Sunken Meadow 
Member, (2) the Rushmere Member, (3) the Morgarts Beach Member, and (4) the Moore House Member (Ward and Blackwelder, 1980). At the Station, the Sunken Meadow Member contains shelly fine to coarse grained sand and is lithologically identical to the Rushmere Member, which contains shelly fine to coarse grained sand and silty sand (C. Richard Berquist, oral commun., 1997). The Morgarts Beach Member contains clay, clayey silt, and sandy to silty clay. The Moore House Member contains shell hash, clayey or sandy shell hash, very fine- to medium-grained sand, or shelly clay. Above the Moore House Member is a weathered zone and a fourth unconformity.

The upper Pliocene Sedley Formation unconformably overlies the Yorktown Formation in the vicinity of the Station (Bick and Coch, 1969; Johnson and others, 1982; C. Richard Berquist, written commun., 1994). Pollen samples collected from this horizon on opposite sides of the Camp Peary scarp indicate that the Sedley Formation is truncated by the scarp and present only under the Lackey Plain at the Station, west and south of the scarp. At the Station, the Sedley Formation contains clay with or without sand lenses or stringers, sandy or silty clay, or clayey silt.

The upper Pliocene Bacons Castle Formation unconformably overlies the Sedley Formation in the vicinity of the Station (Bick and Coch, 1969; C. Richard Berquist, written commun., 1994). In the vicinity of the Station, the Bacons Castle Formation contains medium to coarse gravelly sands and silt (Bick and Coch, 1969).

The surficial geology of the Croaker flat (terrace and scarp inset, pl. 1) consists of the Pleistocene Shirley Formation and undifferentiated Holocene deposits (fig. 5). The surficial geology of the Lackey Plain at the Station (terrace and scarp inset, pl. 1) consists of the Pleistocene Windsor and Chuckatuck Formations at different terrace elevations and additional Holocene deposits. The Camp Peary scarp (pl. 1) divides the distinct surficial geology of the Lackey Plain from that of the Croaker flat at the Station. The Windsor, Chuckatuck, and Shirley Formations at the Station contain very fine- to very coarse-grained sand (commonly silty to clayey), pebbles, and sandy clay. The Holocene deposits contain clay, silt, or sand with some organic deposits.

Under the Lackey Plain at the Station, the Windsor and Chuckatuck Formations unconformably overlie the Bacons Castle Formation. Under the Croaker flat at the Station, the Shirley Formation unconformably overlies a clay of uncertain stratigraphic designation. Pollen analyses of samples of this clay (table 3, wells 58G64, $58 \mathrm{G} 67$, and 58G75; $9 \mathrm{ft}$ altitude) indicate a relative geologic age of Pliocene to Pleistocene. Below the clay is a sand that contains pollen of Pleistocene age at one well (table 3; 58G66; $4 \mathrm{ft}$ ). At wells 58G65 ( $-2 \mathrm{ft})$, 58G74 $(-2 \mathrm{ft})$, and $58 \mathrm{G} 75(-3 \mathrm{ft})$, scarcity or absence of pollen in this sand precluded age determination. From correlation with lithologic logs from wells 58G54, 58G60, 58G61, 58G62, and 58G77, the sand below the Pliocene/ Pleistocene clay of the Croaker flat unconformably overlies sand in the Rushmere Member of the Yorktown Formation.

In the absence of more definitive stratigraphic information, the stratigraphy of the Croaker flat is interpreted in this report. Below the Rushmere Member of the Yorktown Formation, the Croaker flat stratigraphy is the same as that under the Lackey Plain at the Station. An angular unconformity is present at the top of the Morgarts Beach and Rushmere Members of the Yorktown Formation. The Bacons Castle and Sedley Formations and the Moore House Member of the Yorktown Formation are presumed missing along the angular unconformity, because of the low topographic position of the flat. A Pleistocene clay, potentially as old as the Windsor and the Chuckatuck Formations, overlies the angular unconformity. The Shirley Formation is at land surface (Mixon and others, 1989), above the Pleistocene clay.

\section{Depositional History}

The Station is located west of the outer rim of a late Eocene bolide impact crater (Poag and others, 1994; T. Scott Bruce, Virginia Department of Environmental Quality, oral commun., 1997). The deposition of sedimentary units of Miocene to Pleistocene/Holocene age were affected by the filling of this brecciated and faulted crater (Poag, 1997). Contortion and variable thickening of sedimentary units draping over the projected location of the crater rim is common and apparent in cross sections, maps, and interpretations from earlier studies (Cederstrom, 1957, p. 156; Ward and Blackwelder, 1980, p. 30; Johnson and others, 1985, p. 3; Brockman and Richardson, 1992, p. 11-12).

Miocene and Pliocene sediments at the Station were deposited on a shallow shelf near the western edge of the deeper bolide crater. Silty clays of the Calvert and St. Marys Formations were deposited in a shallow bay during multiple early to middle Miocene marine transgressions (Ward, 1984). Fine-grained sediments of the lower Eastover Formation were deposited in an 
Table 3. Age of pollen samples from selected soil-probe holes at the Naval Weapons Station Yorktown [For locations of observation wells see figure 2]

\begin{tabular}{|c|c|c|c|c|}
\hline $\begin{array}{c}\text { Well } \\
\text { number }\end{array}$ & $\begin{array}{c}\text { Altitude of } \\
\text { sample in feet } \\
\text { above sea level }\end{array}$ & $\begin{array}{c}\text { Geohydrologic } \\
\text { unit }\end{array}$ & $\begin{array}{c}\text { Relative } \\
\text { geologic age of } \\
\text { pollen }\end{array}$ & $\begin{array}{l}\text { Sediment } \\
\text { type }\end{array}$ \\
\hline $57 F 34$ & 29 & Cornwallis Cave aquifer & Pliocene & clay \\
\hline $58 \mathrm{~F} 130$ & 44 & Cornwallis Cave confining unit & Pliocene & sandy clay \\
\hline $58 \mathrm{G} 64$ & 21 & Yorktown confining unit & Pleistocene & organics and clay \\
\hline $58 \mathrm{G} 64$ & -4 & Yorktown confining unit & Pleistocene & clay \\
\hline $58 \mathrm{G} 65$ & 18 & Yorktown-Eastover aquifer & Pleistocene & silt \\
\hline $58 \mathrm{G} 65$ & -2 & Yorktown-Eastover aquifer & indeterminate & sand \\
\hline $58 \mathrm{G} 66$ & 13 & Yorktown-Eastover aquifer & indeterminate $^{(2)}$ & clayey shell hash \\
\hline $58 \mathrm{G} 66$ & 4 & Yorktown-Eastover aquifer & Pleistocene & sand \\
\hline $58 \mathrm{G} 67$ & 7 & Yorktown confining unit & Pliocene & clay \\
\hline $58 \mathrm{G} 74$ & -2 & Yorktown-Eastover aquifer & indeterminate & sand \\
\hline $58 \mathrm{G} 75$ & 9 & Yorktown confining unit & Pleistocene & clay \\
\hline $58 \mathrm{G} 75$ & -3 & Yorktown-Eastover aquifer & indeterminate & sand \\
\hline
\end{tabular}

\footnotetext{
'Pollen analyses performed by Grace Brush, Department of Geography and Environmental Engineering at the Johns Hopkins University, 1997. All dates are qualified as "tentative" by the analyst.

${ }^{2}$ Sample contained insufficient pollen for analysis; relative geologic age of Pleistocene determined from stratigraphic position to underlying sample at 4 feet altitude in well $58 \mathrm{G} 66$.
}

open-marine embayment (Ward and Blackwelder, 1980). Shelly sand of the upper Eastover Formation was deposited in an open-marine, shallow bay (Ward and Blackwelder, 1980). The Yorktown Formation was deposited in environments ranging from an open-marine shallow shelf to backbarrier lagoons and shallowing seas (Ward and Blackwelder, 1980). The Sedley Formation was deposited in rivers and estuaries (Bick and Coch, 1969). The Bacons Castle Formation was deposited in rivers (Bick and Coch, 1969). Pliocene sediments deposited east of the Station within the projected impact crater rim and above the bolide deposit generally are finer grained (noted in geologic logs for wells 58F50, 58F61, and 58F65 — unpublished data on file at the U.S. Geological Survey; Virginia District office) than sediments of correlative units at the Station. The fine grain size of Miocene and Pliocene sediments east of the Station could reflect local deposition in a lagoon or embayment similar to environments interpreted for sediments of this age along the James and York Rivers (Johnson and others, 1993) and at Langley Air Force Base (Allen Brockman, U.S. Geological Survey, unpub. data, 1996) 12 miles southeast of the Station.
Pleistocene and Holocene sediments at the Station were deposited in a drowned-river estuarine setting similar to the modern Chesapeake Bay (Johnson and others, 1987) punctuated by periods of falling sea level and deeply eroded river channels (Hack, 1957; Colman and others, 1990). The Windsor Formation was deposited in lagoons or on a shallow marine shelf (Johnson and others, 1987). The Chuckatuck Formation was deposited in a bay, and the Shirley Formation was deposited in rivers and estuaries (Johnson and others, 1987). The Camp Peary scarp and the angular unconformity between the Pleistocene and Pliocene sediments of the Croaker flat most likely formed during one or more periods of fluctuating sea level documented in other regional studies (Hack, 1957; Colman and others, 1990). For units similar to the Pliocene/Pleistocene organic clay at the Croaker flat, Hack (1957) interpreted a period of rising sea level intermediate between a river and an estuarine stage as the depositional environment. The Holocene sediments were deposited in the estuarine environment, as the rising sea level during the last 18,000 years has flooded the ancestral river channels of the Chesapeake Bay (Colman and others, 1990). 


\section{Aquifers and Confining Units}

The geohydrologic framework of the shallow aquifer system at the Naval Weapons Station Yorktown consists of six units: (1) the Columbia aquifer, (2) the Cornwallis Cave confining unit, (3) the Cornwallis Cave aquifer, (4) the Yorktown confining unit, (5) the Yorktown-Eastover aquifer, and (6) the Eastover-Calvert confining unit as shown on the diagram, map, and geohydrologic sections (fig. 5 and pl. 1). Well data used to construct the contour maps are listed in tables 1 and 2, at the end of this report.

Geophysical logs were used to identify the tops of geohydrologic units. The initial identifications required refinement after comparison with water-level data. Many of the apparent geohydrologic contacts were in the unsaturated zone of the sediments. The final geohydrologic interpretation is based on geophysical-log data in conjunction with water-level data.

An earlier USGS study of the hydrogeology of the adjacent York County (Brockman and Richardson, 1992) is referenced and modified to define the geohydrologic framework of the Station for this report. Interpretations of geohydrologic contacts from some wells in Brockman and Richardson (1992) were revised during this study. One geophysical log at the Station from the earlier study and the earlier interpreted geohydrologic contacts were not used in this study.

The geophysical log from well 58F 18 at the Station's x-ray facility was included in the framework interpretation of Brockman and Richardson (1992). The well $58 \mathrm{~F} 18 \log$ is of marginal quality, and when compared with the new USGS geophysical logs of nearby test holes and soil-probe data, the logging-depth scale was apparently inaccurate. Thus the well $58 \mathrm{~F} 18$ geophysical log in Brockman and Richardson (1992) was not included in the framework interpretation for this Naval Weapons Station Yorktown study.

Following an initial review of new geophysical and geohydrologic data collected at the Station, interpretations of geohydrologic contacts from wells $58 \mathrm{~F} 50$, 58F61, and 58F65 in Brockman and Richardson (1992) were revised for this study (tables 1 and 2). Geohydrologic contacts of the Yorktown-Eastover aquifer are recorded as indistinct signatures on logs from these test wells; the result of deposition of nearly uniform, finegrained sediments in the Yorktown-Eastover aquifer and the Eastover-Calvert confining unit near or within the projected bolide-crater area, east of the Station. The absence of distinct contacts in these geohydrologic units overlying the bolide event is reflected in obscure geophysical signatures, making interpretation difficult. Interpreted geohydrologic contacts for wells $57 \mathrm{~F} 2,58 \mathrm{~F} 3$, and $58 \mathrm{~F} 38$ also were adjusted after reviewing additional geophysical logs and geohydrologic data from the Station (tables 1 and 2).

The mineralogy of the individual geohydrologic units is described more completely in the following sections of this report, but the absence of the clay mineral kaolinite in any of the sediment samples collected during this Naval Weapons Station study (U.S. Army Corps of Engineers, Ohio River Division Laboratory, unpub. data, 1996) is of singular note. Earlier studies have distinguished between fluvial and marine depositional environments based on the kaolinite-to-illite clay-mineral assemblage in the sediments (Staub and Cohen, 1978; Bailey, 1981). These studies relate abundant kaolinite to freshwater deposition and abundant illite to marine deposition. The absence of kaolinite from sediment of Pliocene to Holocene age interpreted to be of fluvial origin (Hack, 1957; Bick and Coch, 1969; Johnson and others, 1987), is perplexing. Kaolinite may have been removed through geochemical changes after deposition or may not have mineralized during an abbreviated sediment transport from granitic-source rocks (Hurlbut and Klein, 1977). Short sediment transport is further supported by the presence of undegraded plagioclase and orthoclase in many of the samples (U.S. Army Corps of Engineers, unpub. data, 1996). Greater consideration of detailed mineralogic analysis and depositional interpretation is beyond the scope of this study, but mineralogic results gathered at the Station merit additional research.

Water-level-altitude maps for each of the three aquifers in the shallow system are described in the following sections. Ground-water flow is in the direction of decreasing head (water pressure + water elevation) (Heath, 1983). Thus water-level-altitude maps are important in providing a general picture of the direction of ground-water flow at the Station and in the adjacent area. All of the water levels referenced in this study are listed in table 2. A primary water-level data set was recorded from selected Station wells on February 3, 1997. This date was selected because all new Station wells and piezometers were completed before and measured on this date, and a comprehensive map could be prepared. The primary water levels do not represent seasonal high, low, or average water-level values. The primary water levels are supplemented by a secondary water-level data set consisting of water levels recorded on other dates or inferred from sediment moisture in test holes. Use of sec- 
ondary water levels to estimate the February 3, 1997, water-level maps in this report is subject to error from seasonal fluctuation and (or) estimates of limited accuracy from boreholes. No significant pumping from shallow-system aquifers is recorded for the York-James Peninsula east of Williamsburg (Kull and Laczniak, 1987). Thus, error in secondary water levels related to anthropogenic effects is estimated to be minimal. Watertable and potentiometric contours on the maps in the following sections are based on the primary water levels, supplementing with the secondary water levels as a general guide only.

\section{Columbia Aquifer}

Brockman and Richardson (1992) defined the Columbia aquifer in York County as the unconfined aquifer in sediments of Pleistocene and Holocene age. At the Station, the Columbia aquifer is the unconfined aquifer in the Bacons Castle, Windsor, Chuckatuck, and Shirley Formations of Pliocene/Pleistocene age and in undifferentiated Holocene deposits (fig. 5).

\section{Lithology and Extent}

Sediments of the Columbia aquifer at the Station are recorded in drillers' logs as very fine-grained to very coarse-grained sand with or without pebbles, silty to clayey sand, or sandy clay. Bulk x-ray mineralogy of five Shelby-tube samples shows that aquifer sediments from across the Station consist of 86 to 97 percent quartz with 1 to 2 percent illite, glauconite, or biotite and (or) muscovite (mica); and minor amounts of calcite, plagioclase, orthoclase, chlorite, pyrite, and (or) lepidocrocite (U.S. Army Corps of Engineers, Ohio River Division Laboratory, unpub. data, 1996).

The water table in sediments correlative with the Columbia aquifer (fig. 5) defines the top of the aquifer. The altitude of the water table fluctuates, but the water table as a surface generally is subparallel to the land surface (see top of the saturated zone in pl. 1). The altitude of the top of the water table on February 3, 1997, was highest in the southwestern part of the Station, at more than $80 \mathrm{ft}$ above sea level (58F121; fig. 6). The low altitude extreme for the top of the aquifer is less than $20 \mathrm{ft}$ above sea level in the northeastern part of the Station (fig. 6 ). In the area adjacent to the Station, only one secondary water-level measurement (well 59F74) is included in table 2. This water level indicates the relative altitude of the top of the Columbia aquifer below the lower Grafton Plain to the east of the Station (terrace and scarp inset, pl. 1).

The maximum thickness of the Columbia aquifer on February 3, 1997, was more than $20 \mathrm{ft}$ locally in the southeastern part of the Station (fig. 7). The minimum thickness was less than $5 \mathrm{ft}$ at many locations across the Station (fig. 7). The Columbia sediment is saturated in isolated pods throughout most of the Station, but it is unsaturated in the northwestern area (pl. 1 and fig. 7). The Columbia aquifer is unconfined throughout its extent at the Station.

Ephemeral perched aquifers can form in Columbia sediments above the Yorktown confining unit of the Croaker flat and above the Cornwallis Cave confining unit in other parts of the Station. The perched aquifers form in areas outside the limit of the Columbia aquifer (fig. 7) during periods of excessive rainfall. Perched aquifers sporadically drain to the underlying shallow aquifer system during drier periods and eventually disappear (Fetter, 1994; Guymon, 1994; Bouwer, 1995). Other than delineating the full extent of the Cornwallis Cave and Yorktown confining units above which perched aquifers can form, this study does not characterize the geometry of the perched aquifers at the Station.

\section{Hydraulic Properties}

Horizontal and vertical hydraulic conductivities were determined for the Columbia aquifer. Slug tests were done at 4 wells in the Columbia aquifer (table 4). Horizontal hydraulic conductivities, derived in accordance with the Bouwer technique (1989), range from 0.4 to $8 \mathrm{ft} / \mathrm{d}$. Vertical permeameter tests were done on

Table 4. Horizontal hydraulic conductivity values for the Columbia aquifer, determined from slug tests

[For locations of observation wells see figure 2]

\begin{tabular}{cc}
\hline $\begin{array}{c}\text { Well } \\
\text { number }\end{array}$ & $\begin{array}{c}\text { Horizontal hydraulic } \\
\text { conductivity } \\
\text { (feet per day) }\end{array}$ \\
\hline $58 \mathrm{~F} 106$ & 8 \\
$58 \mathrm{~F} 116$ & .4 \\
$58 \mathrm{~F} 121$ & 1 \\
$58 \mathrm{~F} 161$ & $.4^{(1)}$ \\
\hline
\end{tabular}

${ }^{1}$ Rounded to one significant figure from Baker Environmental, Inc., and Roy F. Weston, Inc., 1993. 


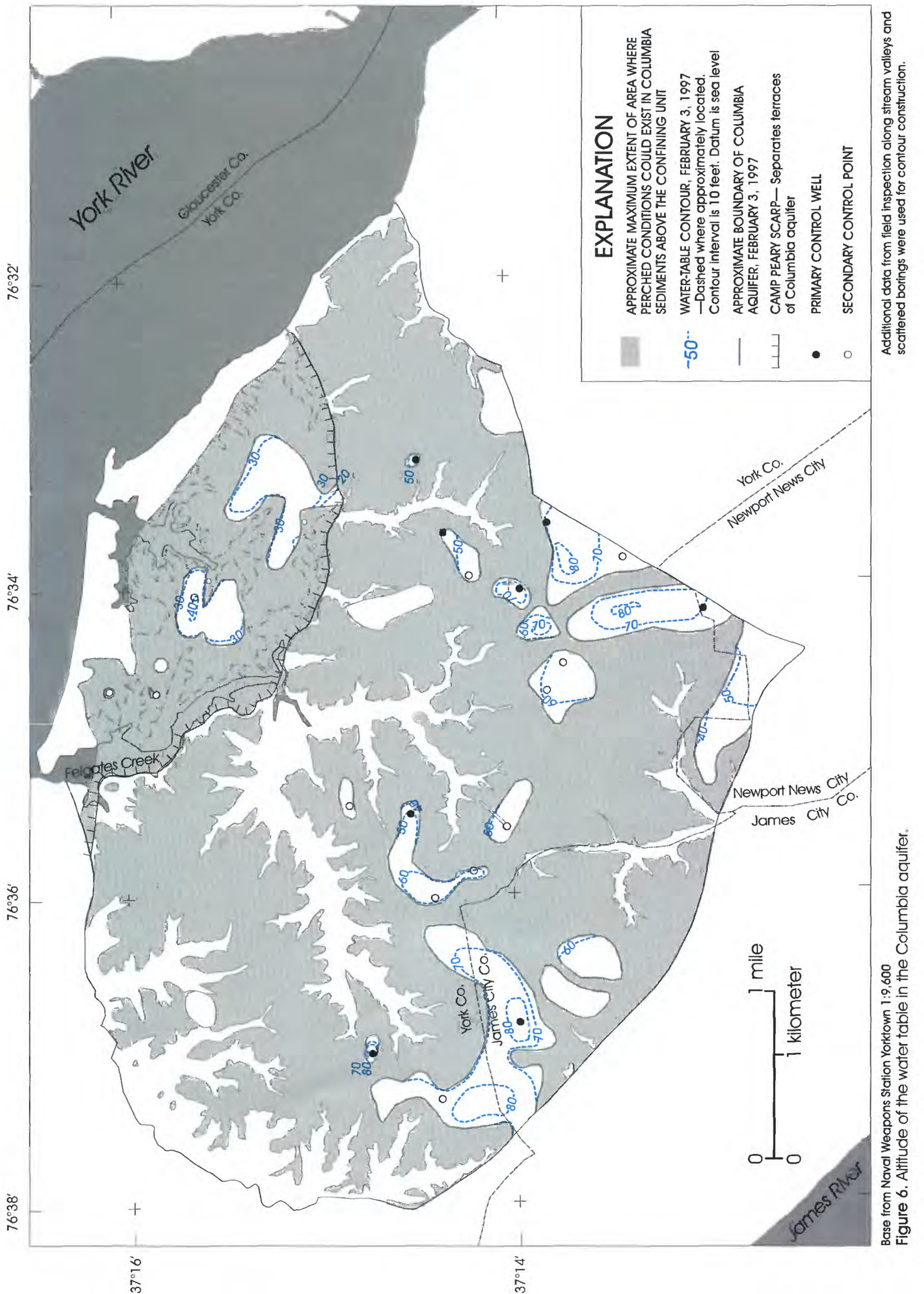




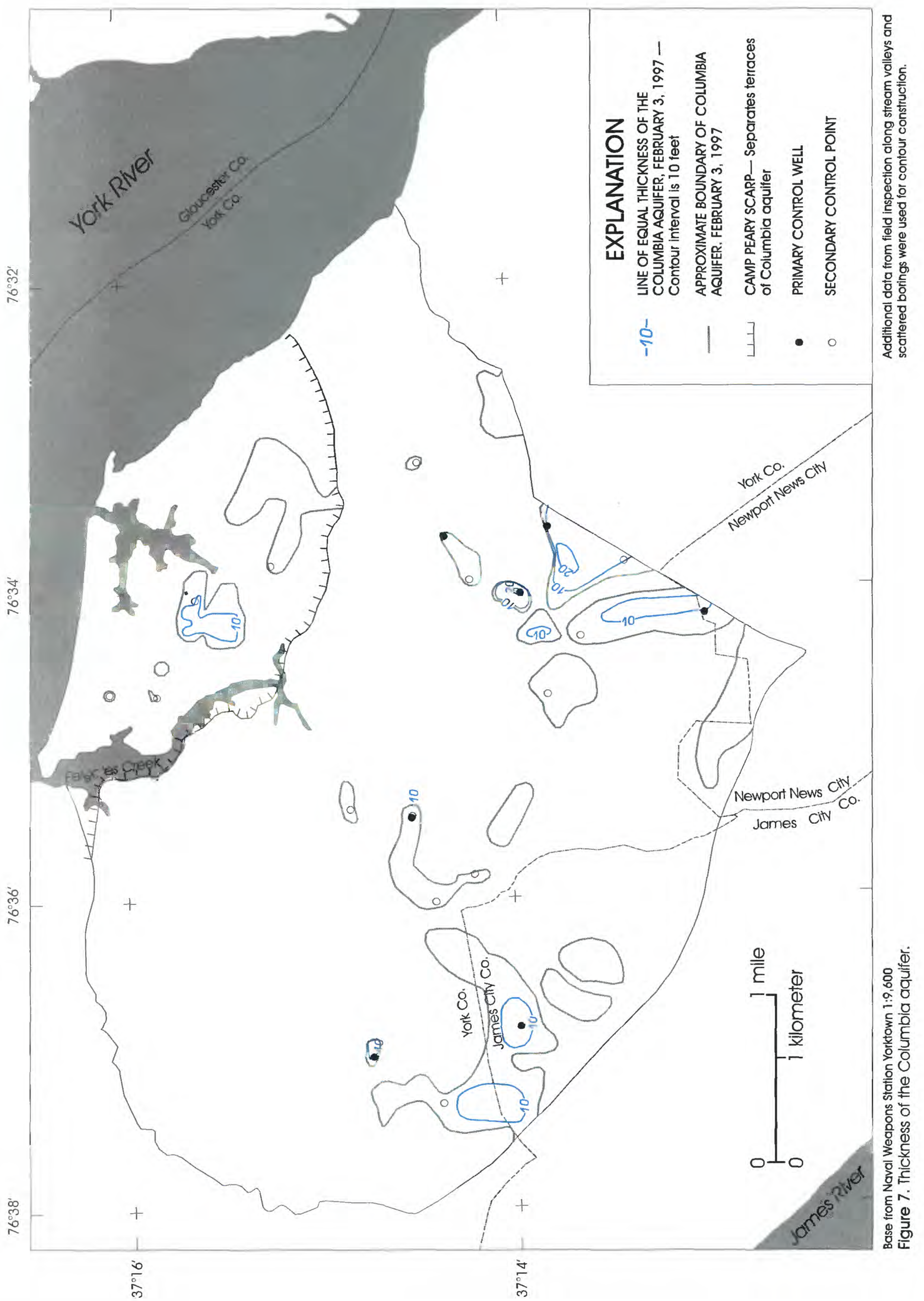


5 samples of the Columbia aquifer (table 5). Vertical hydraulic conductivities range from $1.7 \times 10^{-4}$ to $1.7 \times 10^{-1} \mathrm{ft} / \mathrm{d}$.

\section{Cornwallis Cave Confining Unit}

The Cornwallis Cave confining unit in York County is defined by Brockman and Richardson (1992) as the silt and clay sediments of Pliocene to Holocene age overlying the uppermost confined aquifer. At the Station, the Cornwallis Cave confining unit generally correlates with the upper Pliocene Sedley Formation and silts at the base of the upper Pliocene Bacons Castle Formation (fig. 5). Locally, at the unconformities, the confining unit may include clay or silt in the underlying Moore House Member of the Yorktown Formation or in the overlying formations of Pleistocene age.

Sediments of the Cornwallis Cave confining unit at the Station are recorded in drillers' logs as clay with or without sand lenses or stringers, sandy or silty clay, or clayey silt. Bulk x-ray mineralogy of five Shelby-tube samples shows that confining unit sediments from across the Station consist of 88 to 98 percent quartz with 1 to 5 percent illite, glauconite, or mica; and minor amounts of plagioclase, chlorite, pyrite, and (or) lepidocrocite (U.S. Army Corps of Engineers, Ohio River Division Laboratory, unpub. data, 1996).
The altitude of the top of the confining unit is highest near the western border of the Station at more than 70 $\mathrm{ft}$ above sea level, and lowest immediately northeast of the center of the Station at less than $30 \mathrm{ft}$ above sea level (fig. 8). The maximum thickness of the confining unit is $22 \mathrm{ft}$ (58G49) in the northern area of the Station, and the minimum thickness is less than $5 \mathrm{ft}$ at locations across the Station (fig. 9). The thickness of the confining unit was not contoured because of the absence of a basewide trend. Generally the thickness is $8 \mathrm{ft}$ where the Cornwallis Cave confining unit is present. The Cornwallis Cave confining unit is truncated by the Camp Peary scarp and is present only to the south and west of the scarp. The confining unit is missing beneath the Croaker flat and beneath many of the stream valleys (fig. 9). The confining unit is missing in isolated areas across the Station from the result of ancestral stream erosion (fig. 9).

The Cornwallis Cave confining unit impedes the vertical flow of ground water between the Columbia and Cornwallis Cave aquifers at the Station, as vertical hydraulic conductivities indicate. Vertical permeameter tests were done on five samples of the Cornwallis Cave confining unit (table 5 ). Vertical hydraulic conductivities range from $3.1 \times 10^{-5}$ to $1.4 \times 10^{-2} \mathrm{ft} / \mathrm{d}$.

Table 5. Vertical hydraulic conductivity values for the Columbia aquifer and the underlying Cornwallis Cave confining unit, determined from vertical permeameter tests ${ }^{1}$

[For locations of observation wells see figure 2]

\begin{tabular}{|c|c|c|c|c|c|}
\hline \multirow{2}{*}{$\begin{array}{c}\begin{array}{c}\text { Well } \\
\text { number }\end{array} \\
58 \mathrm{~F} 103\end{array}$} & \multicolumn{3}{|c|}{$\begin{array}{l}\text { Altitude interval } \\
\text { (feet) }\end{array}$} & \multirow{2}{*}{$\begin{array}{c}\begin{array}{c}\text { Geohydrologic } \\
\text { unit }\end{array} \\
\text { Columbia aquifer }\end{array}$} & \multirow{2}{*}{$\begin{array}{c}\begin{array}{c}\text { Vertical hydraulic } \\
\text { conductivity } \\
\text { (feet per day) }\end{array} \\
\frac{7.1 \times 10^{-2}}{}\end{array}$} \\
\hline & 61 & to & 59 & & \\
\hline $58 \mathrm{~F} 108$ & 52 & to & 50 & Columbia aquifer & $8.8 \times 10^{-2}$ \\
\hline $58 \mathrm{~F} 116$ & 75 & to & 73.5 & Columbia aquifer & $1.7 \times 10^{-4}$ \\
\hline $58 \mathrm{~F} 116$ & 64 & to & 62 & Columbia aquifer & $6.0 \times 10^{-2}$ \\
\hline $58 \mathrm{~F} 120$ & 69.5 & to & 68 & Columbia aquifer & $1.7 \times 10^{-1}$ \\
\hline $58 \mathrm{~F} 99$ & 34.5 & to & 32.5 & Cornwallis Cave confining unit & $5.1 \times 10^{-3}$ \\
\hline $58 \mathrm{~F} 103$ & 55.5 & to & 53.5 & Cornwallis Cave confining unit & $1.4 \times 10^{-2}$ \\
\hline $58 \mathrm{~F} 108$ & 43.5 & to & 41.5 & Cornwallis Cave confining unit & $3.1 \times 10^{-5}$ \\
\hline $58 \mathrm{~F} 113$ & 58 & to & 56 & Cornwallis Cave confining unit & $1.3 \times 10^{-3}$ \\
\hline $58 \mathrm{~F} 120$ & 63.5 & to & 62.5 & Cornwallis Cave confining unit & $2.6 \times 10^{-3}$ \\
\hline
\end{tabular}

\footnotetext{
${ }^{1}$ Vertical permeameter tests conducted by U.S. Army Corps of Engineers, Ohio River Division Laboratory, unpub. data, 1996.
} 


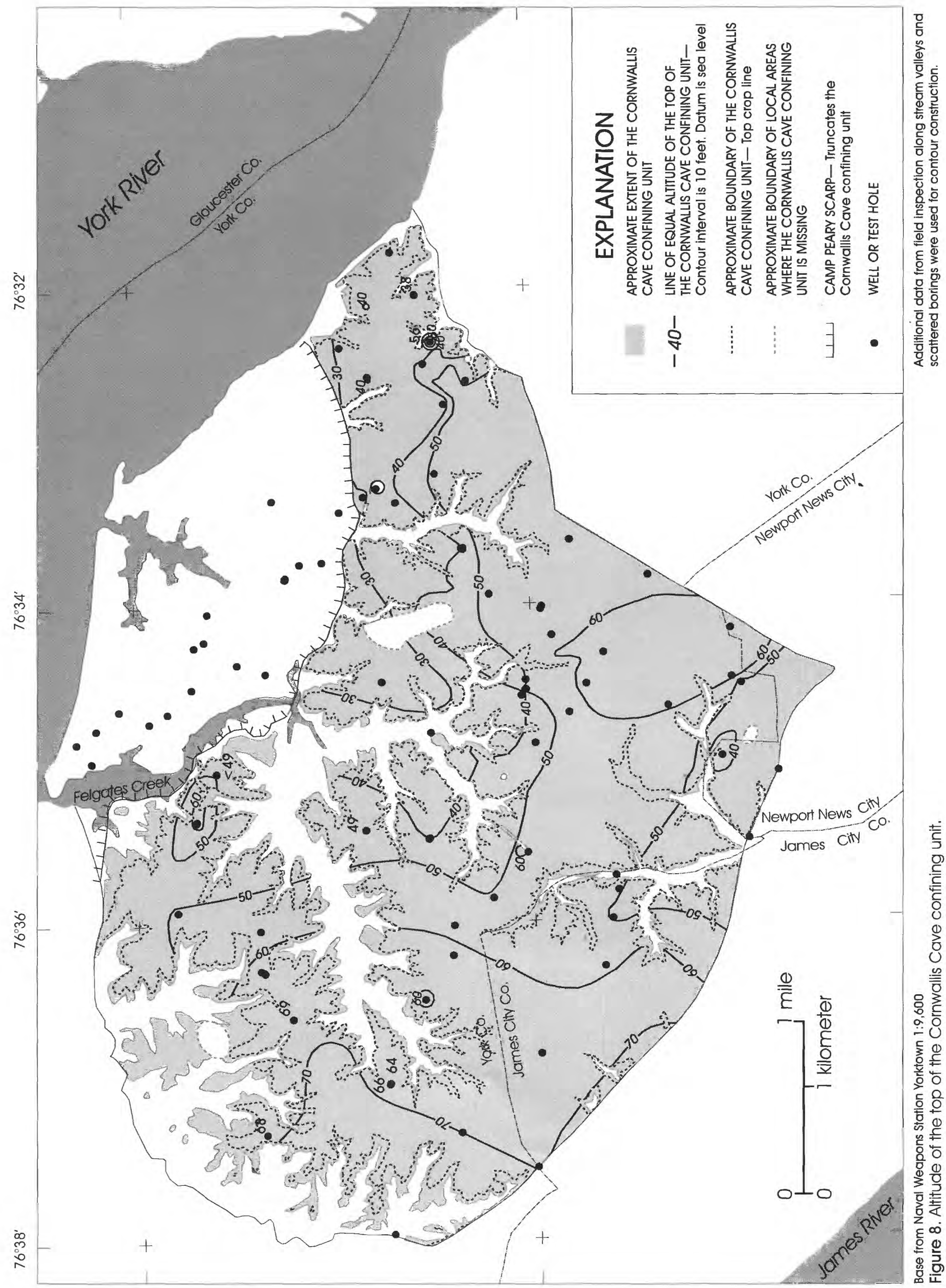




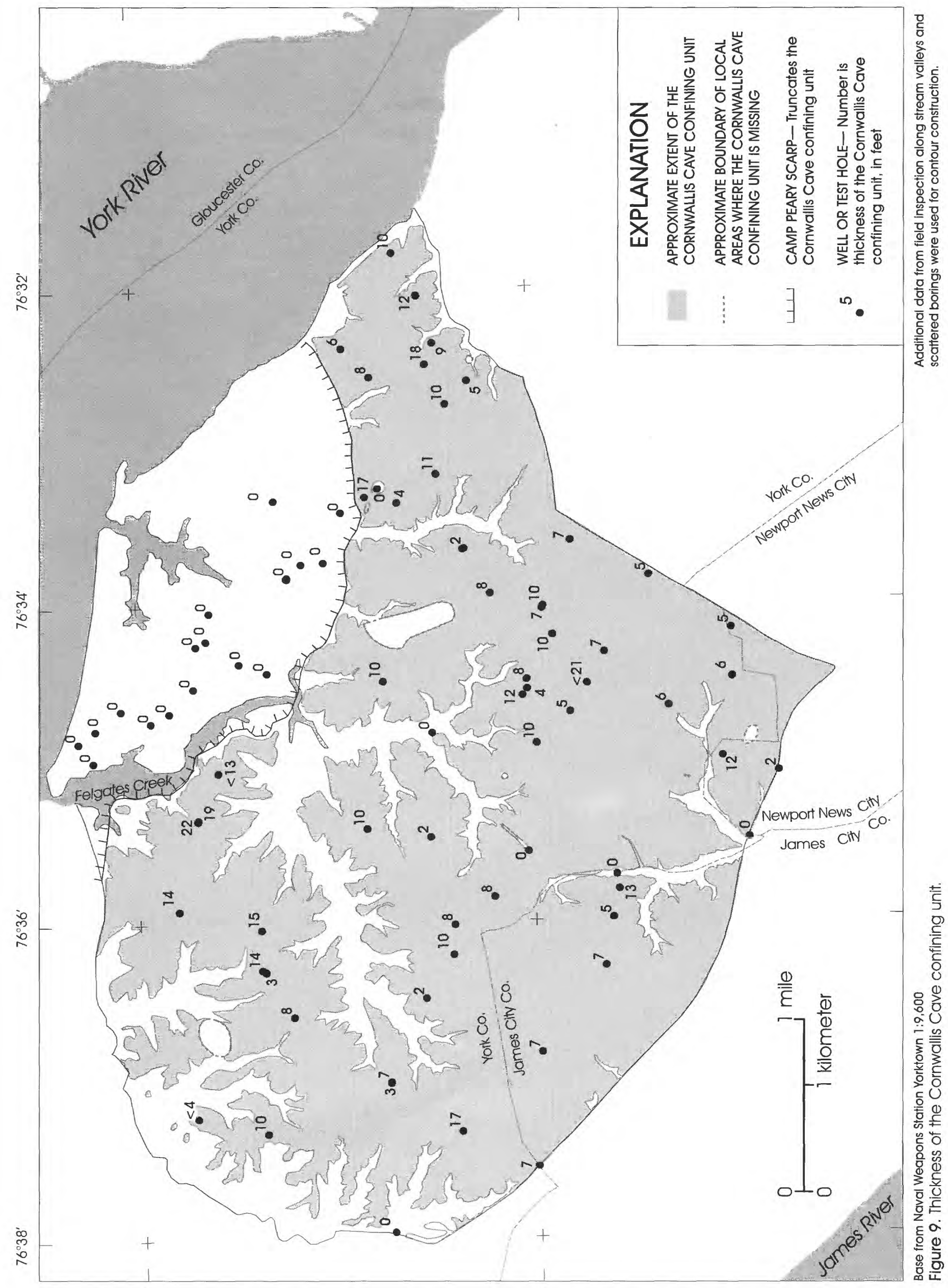




\section{Cornwallis Cave Aquifer}

Brockman and Richardson (1992) defined the Cornwallis Cave aquifer, for the York County area, as the aquifer in sediments of the Moore House Member of the Yorktown Formation, including the confined aquifer in overlying sediments. For this report, the definition is narrowed to the following: The aquifer in sediments of the Moore House Member of the Yorktown Formation with some minor local exceptions (fig. 5). Locally under the Lackey Plain, sandy sediments of younger ages directly overlie the Moore House Member along the upper unconformity surface. At these locations, the younger sediments are included in the Cornwallis Cave aquifer.

\section{Lithology and Extent}

Sediments of the Cornwallis Cave aquifer at the Station are recorded in drillers' logs as shell hash with or without some coquina, clay, or silt; clayey or sandy shell hash; very fine-grained to medium-grained sand; or shelly clay. Bulk x-ray mineralogy of 13 Shelby-tube samples shows that aquifer sediments from across the Station consist of 76 percent quartz, 18 percent calcite, and 2 percent pyrite; minor amounts of siderite, plagioclase, orthoclase, illite, glauconite or mica; and chlorite, chalcopyrite, and (or) lepidocrocite (U.S. Army Corps of Engineers, Ohio River Division Laboratory, unpub. data, 1996). The high percentage of calcite in the sediments of the Cornwallis Cave aquifer may result in the isolated development of karst solution features in some parts of the Station, as noted at other York County locations (Brockman and Richardson, 1992, p. 21; Johnson and others, 1993, p. 24). Water losses possibly resulting from increased porosity is due to dissolution of sediments in this unit (recorded at all seven USGS well clusters at the Station during drilling in the Cornwallis Cave aquifer). No significant voids, however were identified at the USGS well clusters during subsequent soil-probe investigations.

The altitude of the top of the confined aquifer is highest near the western boundary of the Station at more than $60 \mathrm{ft}$ above sea level (fig. 10). The lowest altitude for the top of the confined aquifer is immediately northeast of the center of the Station, at less than $20 \mathrm{ft}$ above sea level. The aquifer top is not contoured in the unconfined area of the aquifer. In the unconfined area, the water table in sediments correlative with the Cornwallis Cave aquifer (fig. 5) defines the top of the aquifer. The water table of the unconfined aquifer and the potentiometric surface of the confined aquifer are contoured in figure 11 .
The highest water level in wells screened to the Cornwallis Cave aquifer on February 3, 1997, was more than $80 \mathrm{ft}$ above sea level in the southwestern part of the Station (fig. 11). The lowest water level on this same date was less than $20 \mathrm{ft}$ above sea level near the easternmost point of the Station. A potentiometric high in the Cornwallis Cave aquifer extends from west to east across the south central part of the Station (fig. 11), indicating a divide between ground water flowing northward toward the York River and that flowing southward toward the James River. In the area adjacent to the Station, secondary water-level measurements from wells $58 \mathrm{~F} 63$ and $59 \mathrm{~F} 73$ in the Cornwallis Cave aquifer are shown in table 2. These water levels are intermediate in altitude relative to the Station and indicate water levels in wells in the aquifer below the lower Grafton Plain to the east of the Station (pl. 1).

The maximum thickness of the Cornwallis Cave aquifer is more than $60 \mathrm{ft}$ above sea level near the western boundary of the Station (fig. 12). The minimum thickness of the aquifer is less than $5 \mathrm{ft}$ in scattered areas across the northeastern Station (fig. 12). The Cornwallis Cave aquifer is truncated by the Camp Peary scarp and is present only to the south and west of the scarp. The aquifer is missing beneath the Croaker flat, and part of the eroded Felgates Creek and other stream valleys (fig. 12). The aquifer is confined generally beneath the elevated areas between stream valleys in the southern half of the Station but unconfined in the remaining areas of the Station (fig. 11).

Locally in the western part of the Station, an additional clay unit is present in the middle of the Cornwallis Cave aquifer. This clay unit is present at wells 57F34, $58 \mathrm{G} 79$, and test well 58G59. Though the geometry of the mid-Cornwallis Cave aquifer clay unit is too localized to have much bearing on the ground-water flow at the Station, it may be of greater thickness and more extensive to the west of the Station.

\section{Hydraulic Properties}

Horizontal and vertical hydraulic conductivities and transmissivities were determined for the Cornwallis Cave aquifer. Slug tests were done at six wells in the Cornwallis Cave aquifer (table 6). Horizontal hydraulic conductivities, derived by the Bouwer technique (1989), range from 0.3 to $9 \mathrm{ft} / \mathrm{d}$. Transmissivities for confined aquifers were derived by the method described by Cooper and others, 1967. Aquifer transmissivities based on data from three wells range from 20 to $400 \mathrm{ft}^{2} / \mathrm{d}$. This 


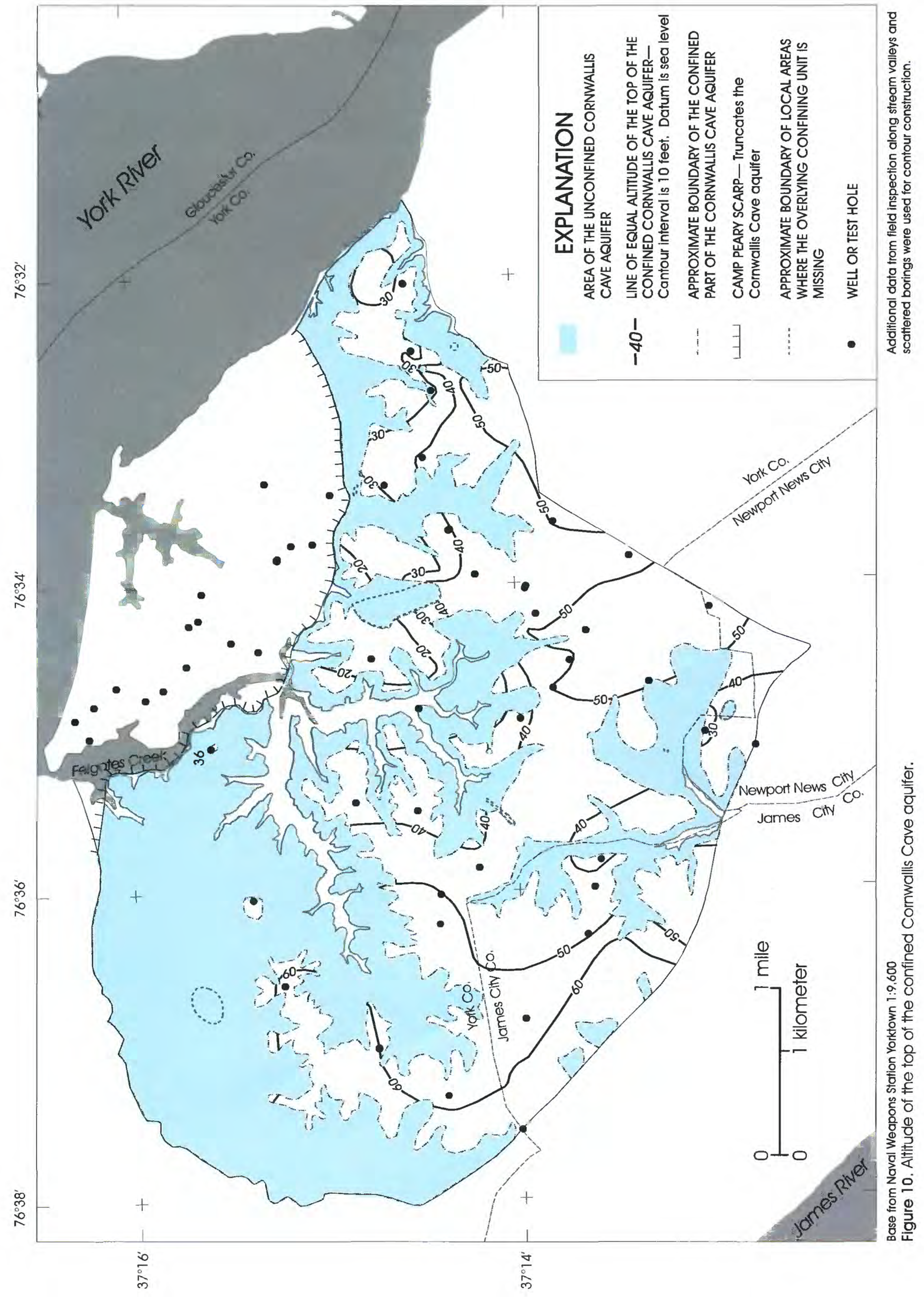




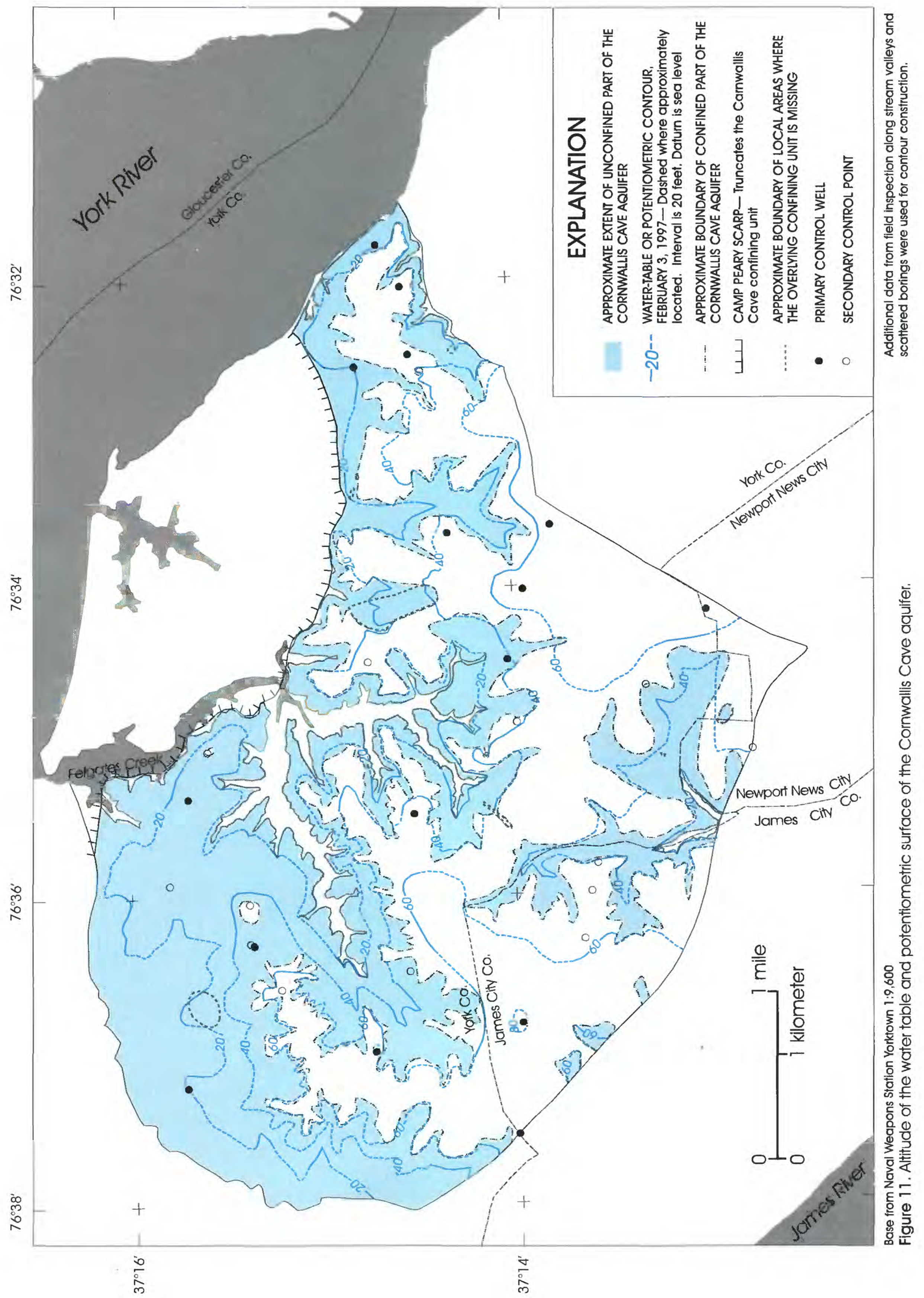




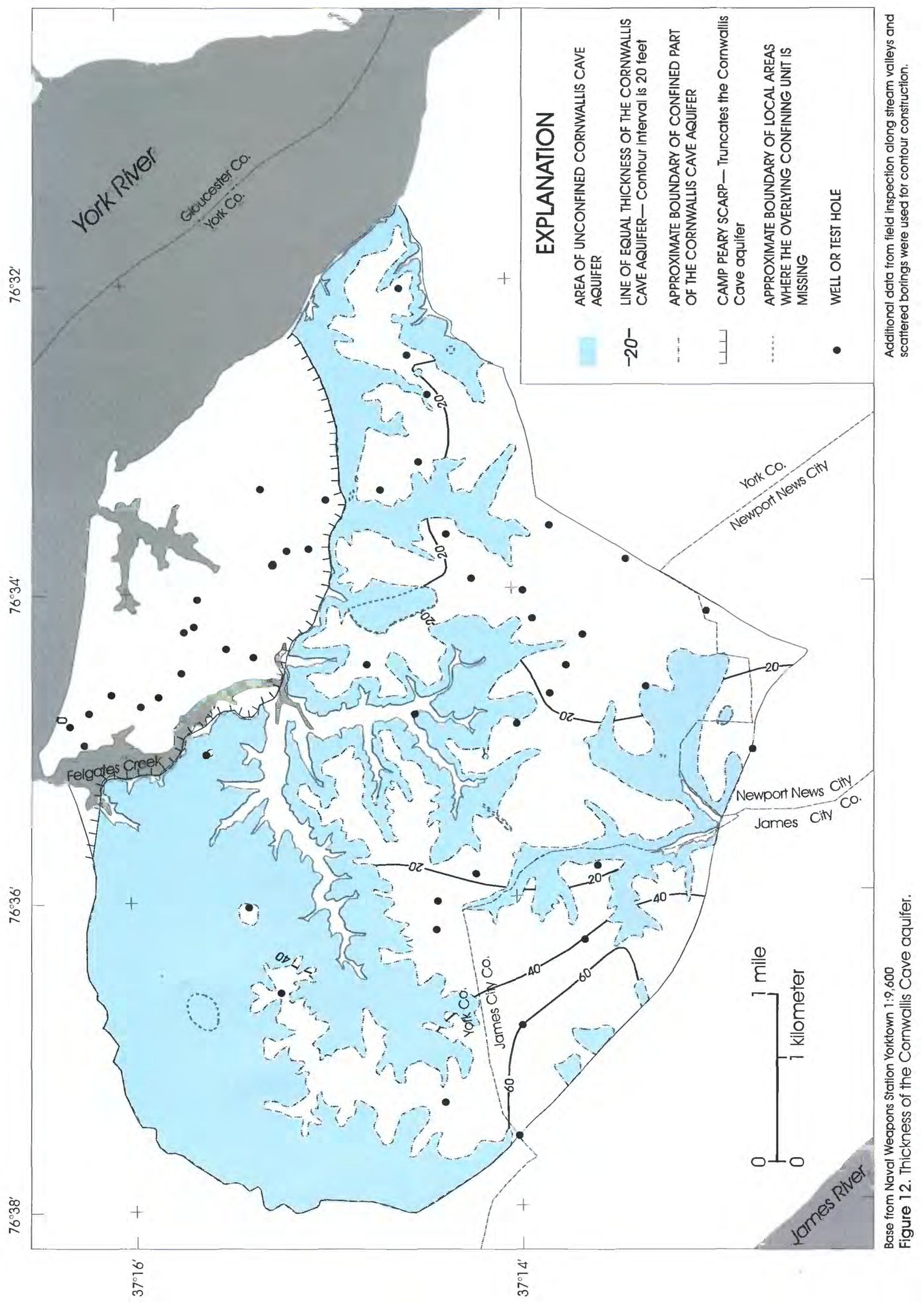


Table 6. Horizontal hydraulic conductivity and transmissivity values for the Cornwallis Cave aquifer, determined from slug tests

[Transmissivity not determined for unconfined aquifers, $\mathrm{U}$; for locations of observation wells see figure 2]

\begin{tabular}{lcc}
\hline Well number & $\begin{array}{c}\text { Horizontal } \\
\text { hydraulic } \\
\text { conductivity } \\
\text { (feet per day) }\end{array}$ & $\begin{array}{c}\text { Transmissivity } \\
\text { (feet squared } \\
\text { per day) }\end{array}$ \\
\hline $58 \mathrm{~F} 100$ & 4 & $\mathrm{U}$ \\
$58 \mathrm{~F} 105$ & 5 & 30 \\
$58 \mathrm{~F} 110$ & 9 & $\mathrm{U}$ \\
$58 \mathrm{~F} 115$ & 9 & 400 \\
$58 \mathrm{~F} 120$ & .4 & 20 \\
$58 \mathrm{G} 57$ & .3 & $\mathrm{U}$ \\
\hline
\end{tabular}

${ }^{1}$ Calculated by method in Bouwer, 1989.

${ }^{2}$ Calculated by method in Cooper and others, 1967.

method (Cooper and others, 1967) can be used to determine transmissivities only for confined aquifers. Horizontal hydraulic conductivities of the confined aquifers at the Station determined by the Bouwer technique generally are one-tenth the magnitude of horizontal hydraulic conductivities converted from transmissivities in the Cooper technique (George Harlow, U.S. Geological Survey, unpub. data, 1997). Vertical permeameter tests were done on 13 samples of the Cornwallis Cave aquifer (table 7). Vertical hydraulic conductivities range from $6.2 \times 10^{-4}$ to $2.4 \times 10^{-1} \mathrm{ft} / \mathrm{d}$.

\section{Yorktown Confining Unit}

The Yorktown confining unit in York County is defined by Brockman and Richardson (1992) as the silt or clay of the Morgarts Beach Member of the Yorktown Formation. This unit is redefined, at the Station, in this report as the silt or clay of the Morgarts Beach Member under the Lackey Plain at the Station and including the overlying silt or clay of Pleistocene age under Croaker flat at the Station (fig. 5). At Croaker flat, units between the Morgarts Beach Member and younger Pleistocene clays apparently are missing along an angular unconformity (table 3; fig. 5). Pollen analyses indicate that the Morgarts Beach Member is missing locally below Croaker flat along the angular unconformity surface at the Station (table 3-wells 58G65, 58G66, 58G75; fig. 5).
Sediments of the Yorktown confining unit at the Station are recorded in drillers' logs as clay, clayey silt, sandy clay, or silty clay with or without some shell hash or sand stringers. Bulk x-ray mineralogy of six Shelbytube samples shows confining unit sediments from across the Station consists of 85 to 97 percent quartz with 1 to 3 percent illite, glauconite, or mica; 1 percent pyrite; and minor amounts of plagioclase and (or) chlorite (U.S. Army Corps of Engineers, Ohio River Division Laboratory, unpub. data, 1996).

The altitude of the top of the confining unit is highest in a small area in the northeastern part of the Station, at more than $40 \mathrm{ft}$ above sea level and lowest in the southwestern part of the Station, at altitudes below sea level (fig. 13). The maximum thickness of the confining unit is $36 \mathrm{ft}$ in the northeastern part of the Station (58G77), and the minimum thickness is less than $5 \mathrm{ft}$ at scattered locations across the Station (fig. 14). As a result of local variability and the absence of a basewide trend, the thickness of the confining unit was not contoured. Generally the thickness is $14 \mathrm{ft}$ where the Yorktown confining unit is present. The confining unit is missing along the ancestral York River channel, beneath part of the eroded Felgates Creek stream valley in the Lackey Plain area of the Station, and in two isolated areas of apparent Pliocene erosion (fig. 14).

The Yorktown confining unit impedes the vertical flow of ground water between the Cornwallis Cave and Yorktown-Eastover aquifers under the Lackey Plain at the Station and between the Columbia and YorktownEastover aquifers beneath the Croaker flat at the Station. Vertical permeameter tests were done on six samples of the Yorktown confining unit (table 7). Vertical hydraulic conductivities range from $1.3 \times 10^{-5}$ to $7.4 \times 10^{-3} \mathrm{ft} / \mathrm{d}$.

\section{Yorktown-Eastover Aquifer}

For York County, Brockman and Richardson (1992) defined the Yorktown-Eastover aquifer as the aquifer in sandy and shelly sediments of the Cobham Bay Member of the Eastover Formation and the Sunken Meadow and Rushmere Members of the Yorktown Formation. At the Station, the Yorktown-Eastover aquifer contains these Miocene and Pliocene sediments but also includes some sandy sediments of Pleistocene age (fig. 5). Pleistocene sediments in the Yorktown-Eastover aquifer are present along the angular unconformity beneath the Croaker flat (table 3). 


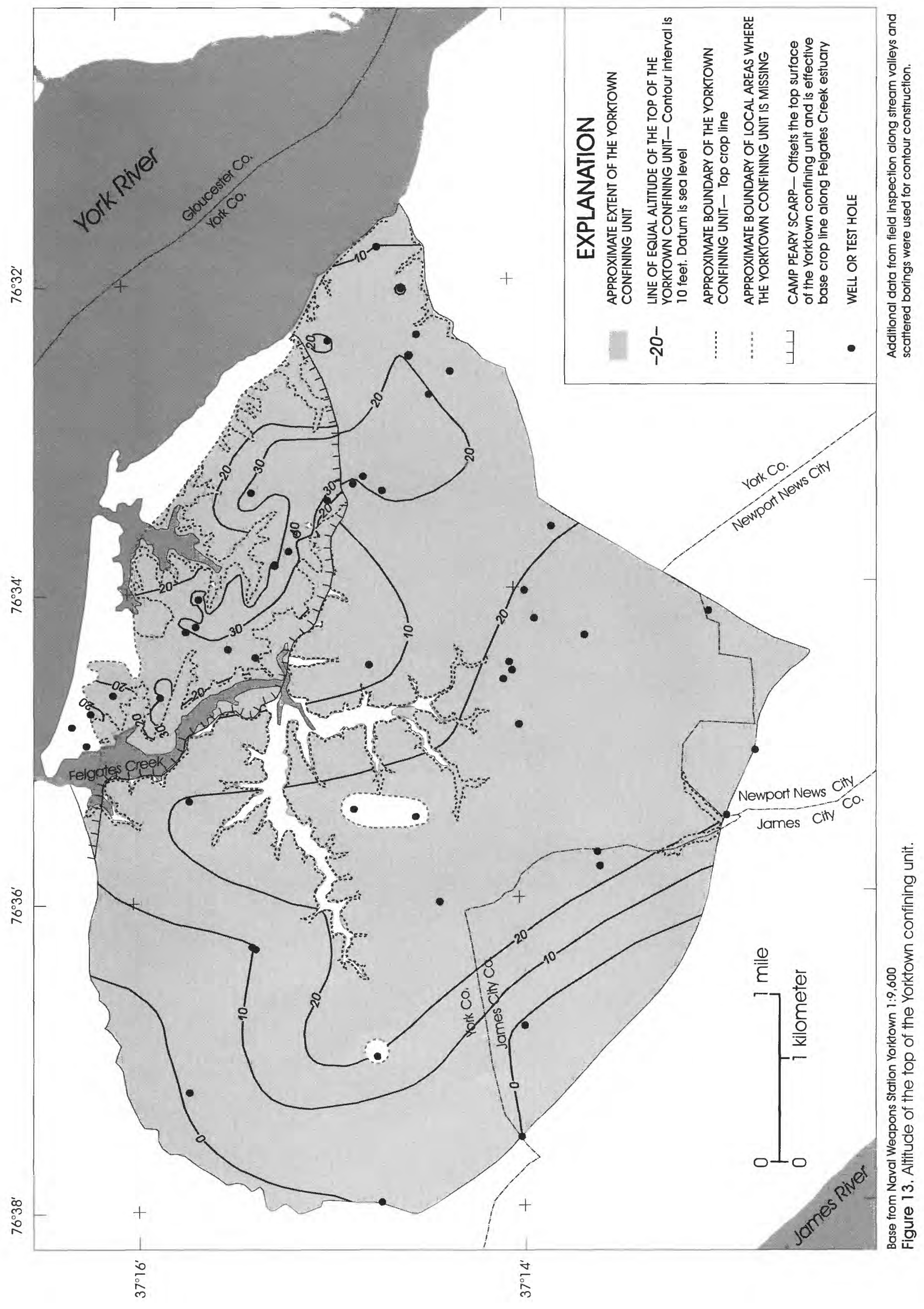




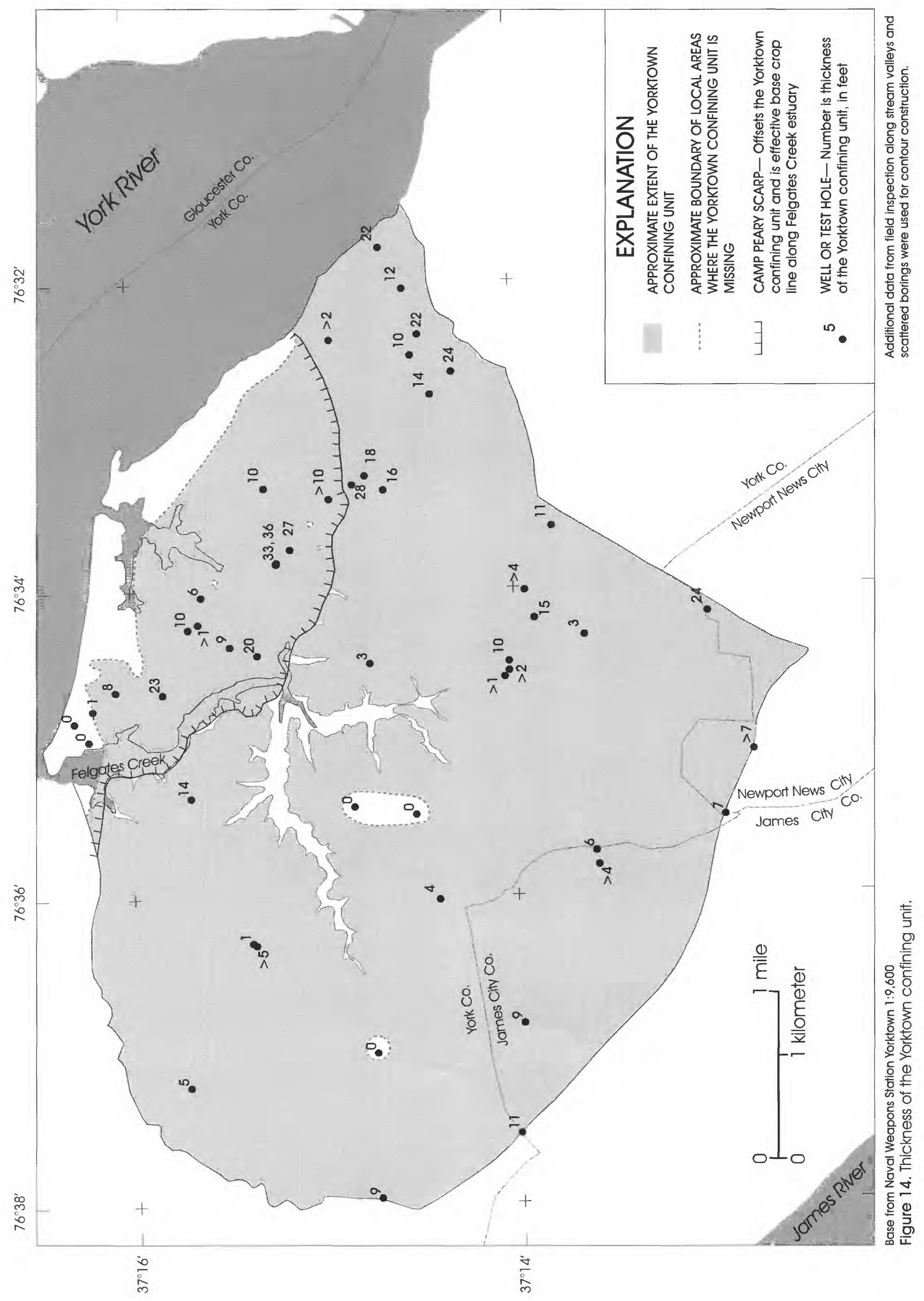


Table 7. Vertical hydraulic conductivity values for the Cornwallis Cave aquifer and the underlying Yorktown confining unit, determined from vertical permeameter tests ${ }^{1}$

[For locations of observation wells see figure 2]

\begin{tabular}{|c|c|c|c|c|c|}
\hline $\begin{array}{c}\text { Well } \\
\text { number }\end{array}$ & & $\begin{array}{r}\text { Altituo } \\
\text { interv } \\
\text { (feet) }\end{array}$ & & $\begin{array}{c}\text { Geohydrologic } \\
\text { unit }\end{array}$ & $\begin{array}{c}\text { Vertical hydraulic } \\
\text { conductivity } \\
\text { (feet per day) }\end{array}$ \\
\hline 58 F99 & 28.5 & to & 27 & Cornwallis Cave aquifer & $4.8 \times 10^{-3}$ \\
\hline $58 \mathrm{~F} 99$ & 16.5 & to & 14.5 & Cornwallis Cave aquifer & $1.6 \times 10^{-1}$ \\
\hline $58 \mathrm{~F} 103$ & 25.5 & to & 24.5 & Cornwallis Cave aquifer & $6.8 \times 10^{-3}$ \\
\hline $58 \mathrm{~F} 104$ & 39.5 & to & 38.5 & Cornwallis Cave aquifer & $1.0 \times 10^{-2}$ \\
\hline $58 \mathrm{~F} 109$ & 29.5 & to & 28 & Cornwallis Cave aquifer & $6.2 \times 10^{-4}$ \\
\hline $58 F 113$ & 52.5 & to & 50.5 & Cornwallis Cave aquifer & $1.3 \times 10^{-1}$ \\
\hline $58 \mathrm{~F} 115$ & 31.5 & to & 29.5 & Cornwallis Cave aquifer & $9.6 \times 10^{-3}$ \\
\hline $58 \mathrm{~F} 118$ & 2.5 & to & 1 & Cornwallis Cave aquifer & $2.7 \times 10^{-2}$ \\
\hline $58 \mathrm{~F} 118$ & -3.5 & to & -4.5 & Cornwallis Cave aquifer & $5.7 \times 10^{-2}$ \\
\hline $58 \mathrm{~F} 119$ & 49.5 & to & 47.5 & Cornwallis Cave aquifer & $1.2 \times 10^{-1}$ \\
\hline 58G55 & 41 & to & 39.5 & Cornwallis Cave aquifer & $1.9 \times 10^{-1}$ \\
\hline $58 \mathrm{G} 55$ & 8 & to & 6.5 & Cornwallis Cave aquifer & $2.4 \times 10^{-1}$ \\
\hline $58 \mathrm{G} 55$ & 34 & to & 32 & clay in Cornwallis Cave aquifer & $6.8 \times 10^{-2}$ \\
\hline $58 \mathrm{~F} 98$ & 5.5 & to & 3.5 & Yorktown confining unit & $7.4 \times 10^{-3}$ \\
\hline $58 \mathrm{~F} 103$ & 16.5 & to & 14.5 & Yorktown confining unit & $1.2 \times 10^{-4}$ \\
\hline $58 \mathrm{~F} 108$ & 20.5 & to & 18.5 & Yorktown confining unit & $4.0 \times 10^{-5}$ \\
\hline $58 \mathrm{~F} 113$ & 15 & to & 13 & Yorktown confining unit & $1.6 \times 10^{-4}$ \\
\hline $58 \mathrm{~F} 118$ & -4.5 & to & -5.5 & Yorktown confining unit & $1.3 \times 10^{-5}$ \\
\hline 58G55 & 1 & to & -1 & Yorktown confining unit & $1.2 \times 10^{-4}$ \\
\hline
\end{tabular}

\footnotetext{
'Vertical permeameter tests conducted by U.S. Army Corps of Engineers, Ohio River Division Laboratory, written commun., 1996.
}

\section{Lithology and Extent}

Sediments of the Yorktown-Eastover aquifer at the Station are recorded in drillers' logs as very fine-grained to coarse-grained sand, silty sand, silt, or sandy clay with or without some conglomerate, shell hash, and clay. Bulk $\mathrm{x}$-ray mineralogy of 27 Shelby-tube samples shows that aquifer sediments from across the Station consist of 87 percent quartz; 8 percent calcite; 1 percent illite, glauconite, or mica; 1 percent pyrite; 0.5 percent lepidocrocite; and minor amounts of plagioclase, orthoclase, and (or) chlorite. Ankerite was present in one sample (U.S. Army Corps of Engineers, Ohio River Division Laboratory, unpub. data, 1996).

The altitude of the top of the confined part of the Yorktown-Eastover aquifer is highest in three isolated areas in the eastern part of the Station at more than $20 \mathrm{ft}$ above sea level (fig. 15). The lowest altitude of the confined aquifer top is more than $10 \mathrm{ft}$ below sea level at two locations on opposite extremes of the Station- the eastern and southwestern boundaries (fig. 15). The aquifer top is not contoured in the unconfined area of the aquifer (fig. 15). In the unconfined area, the water table in sediments correlative with the Yorktown-Eastover aquifer (fig. 5) defines the top of the aquifer. The water table of the unconfined aquifer and the potentiometric surface of the confined aquifer are contoured in figure 16. The highest water level in wells screened to the Yorktown-

Eastover aquifer on February 3, 1997, was more than 60 $\mathrm{ft}$ above sea level in the southeastern part of the Station (fig. 16). The lowest water levels on this same date were less than $10 \mathrm{ft}$ above sea level near the York River estuary. A west-to-east potentiometric high in the YorktownEastover aquifer divides the ground-water flow toward the York River from that toward the James River (fig. 16).

In the area adjacent to the Station, seven secondary water-level measurements from wells in the YorktownEastover aquifer are shown in figure 17. The secondary water level to the west of the Station (well 57F14) is slightly higher than the altitude of the water-level 


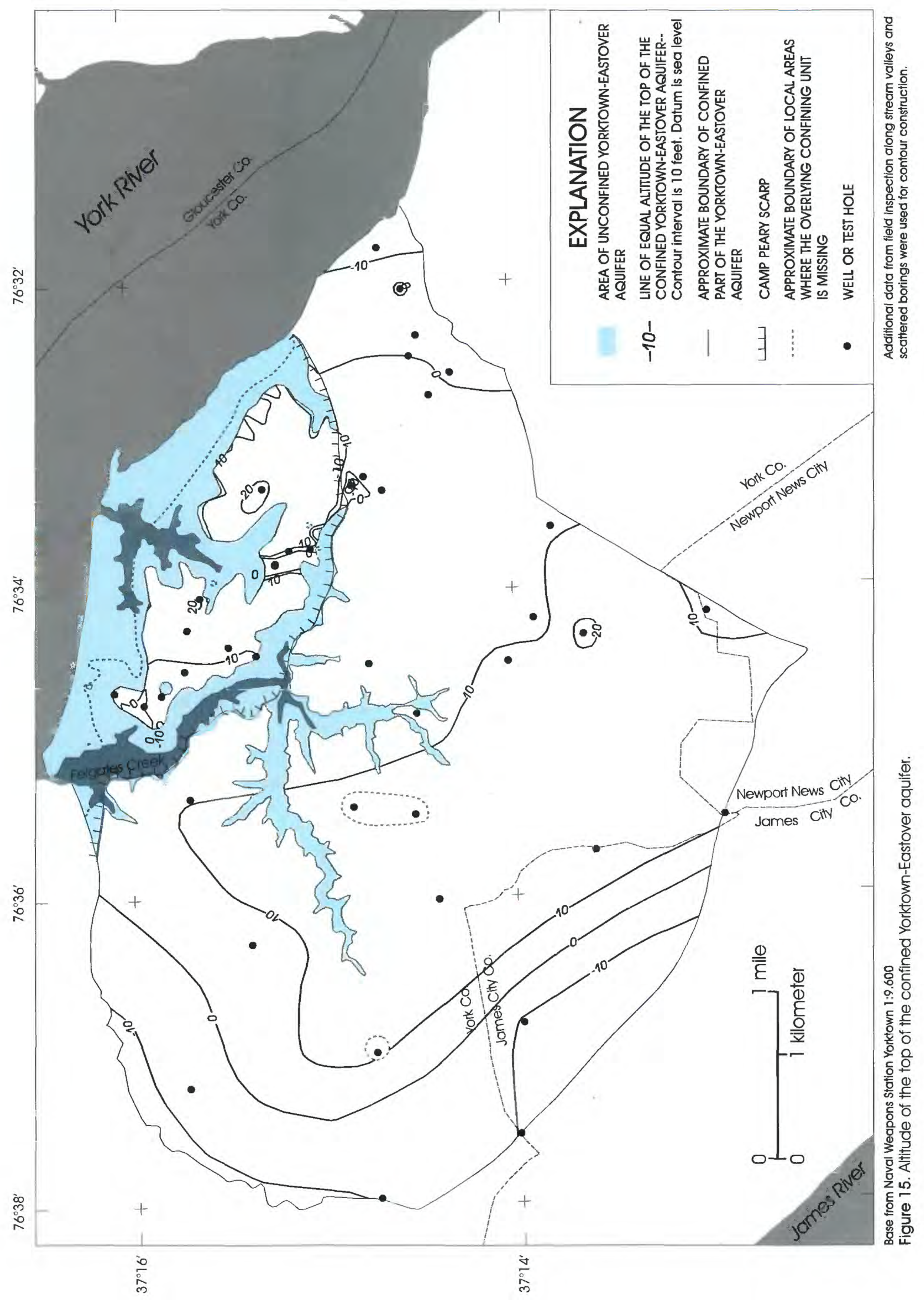




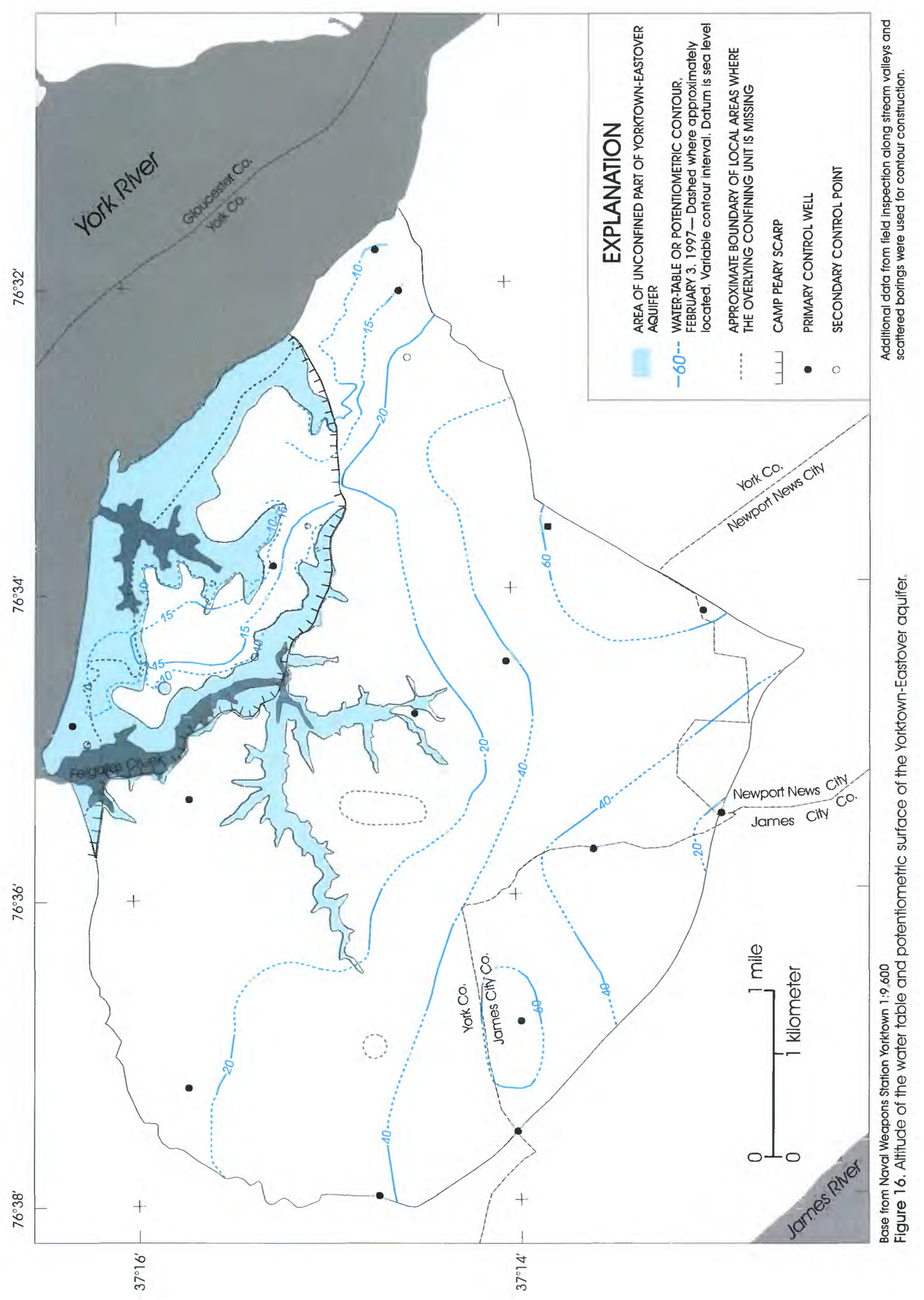




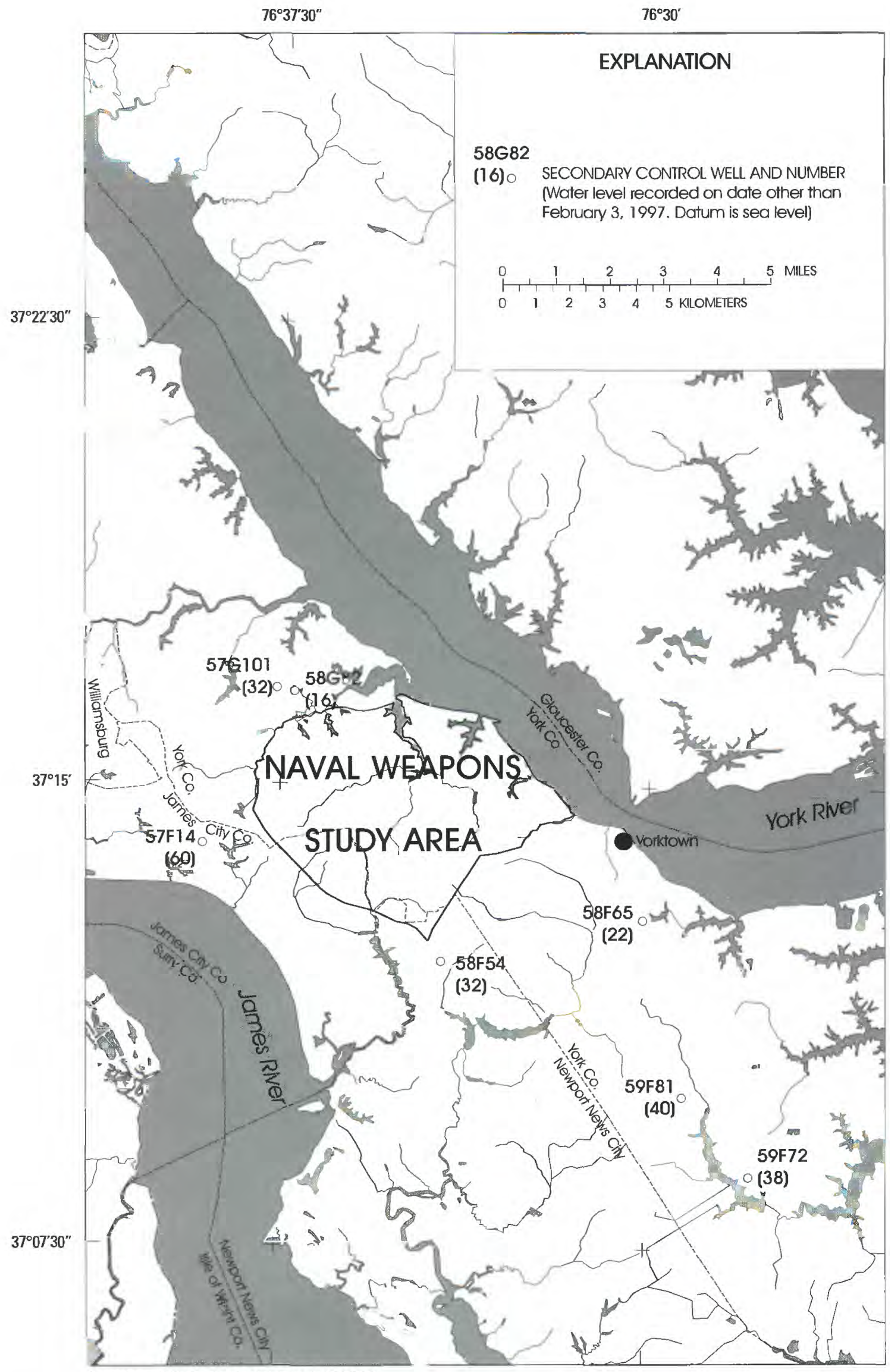

Base from U. S. Geological Survey 1:100,000

Figure 17. Altitude of the water table and potentiometric surface of the Yorktown-Eastover aquifer in area adjacent to the Naval Weapons Station Yorktown. 
contours along the western Station boundary. The apparent general direction of ground-water flow in the Yorktown-Eastover aquifer is toward the Station from well 57F14. Secondary water levels to the northwest of the Station (wells 57G101 and 58G82) are higher than or comparable to the water levels and altitudes of the waterlevel contours along the northwestern Station boundary. From the northwest, the apparent general direction of ground-water flow in the Yorktown-Eastover aquifer is toward either the Station or the York River and the tributary drainages, in a direction parallel to ground-water flow at the Station.

Secondary water levels to the southeast (wells $58 \mathrm{~F} 54,58 \mathrm{~F} 65,59 \mathrm{~F} 72$, and 59F81), are all lower than or comparable to the altitudes of the water levels and waterlevel contours along the southeastern Station boundary. The apparent general direction of ground-water flow in the Yorktown-Eastover aquifer from the Station is toward either the southeast or the York River and the tributary drainages, in a direction parallel to ground-water flow at the Station. Water-level contours for the YorktownEastover aquifer at the Station indicate the presence of another local high or ground-water divide along the southeastern Station boundary between wells 58F105 and 58F114 (figs. 2 and 16), in addition to the York-James ground-water divide. Along this part of the Station boundary, ground-water flow in the Yorktown-Eastover aquifer is apparently directed radially outward - west, northwest, and north toward the Station and east and southeast toward the adjacent area.

The maximum thickness of the aquifer is more than $100 \mathrm{ft}$ at two isolated locations in the northeastern part of the Station (fig. 18). The minimum thickness is less than $60 \mathrm{ft}$ through the central part of the Station (fig. 18). The aquifer extends across the entire Station and generally is confined except along the eroded Felgates Creek stream valley and eroded stream valleys of the Croaker flat in the northeast (fig. 18).

Locally in the southeastern and eastern parts of the Station, an additional clay unit is present in the middle of the Yorktown-Eastover aquifer. This clay unit is present at well 58F154 and test wells 58F102, 58F107, 58F112, and 58F117. The mid-Yorktown-Eastover clay possibly is part of the Eastover Formation (C. Richard Berquist, oral commun., 1997). Lenses of this clay can be identified from geophysical-log deflections at test wells 58F50, 58F61, 59F80, and 59F71 (pl. 1, section D-D'). Water levels in wells screened above $(58 \mathrm{~F} 99,58 \mathrm{~F} 104,58 \mathrm{~F} 109$, and 58F114) and below (58F98, 58F103, 58F108, and
58F113) this clay generally do not exhibit significant differences (table 2). The unit apparently has little effect on ground-water flow in the Yorktown-Eastover aquifer.

\section{Hydraulic Properties}

Horizontal and vertical hydraulic conductivities were determined for the Yorktown-Eastover aquifer. Slug tests were done at 18 wells in the Yorktown-Eastover aquifer (table 8). Horizontal hydraulic conductivities, derived in accordance with the Bouwer technique (1989), range from 0.004 to $3 \mathrm{ft} / \mathrm{d}$. Transmissivities (Cooper and others, 1967) from 10 wells range from 0.5 to $40 \mathrm{ft}^{2} / \mathrm{d}$. Vertical permeameter tests were done on 27 samples of the Yorktown-Eastover aquifer (table 9). Vertical hydraulic conductivities of sands in the Yorktown-Eastover aquifer range from $1.7 \times 10^{-5}$ to $4.8 \times 10^{-1} \mathrm{ft} / \mathrm{d}$. Vertical hydraulic conductivities of clays in the aquifer range from $4.0 \times 10^{-6}$ to $1.3 \times 10^{-3} \mathrm{ft} / \mathrm{d}$.

Table 8. Horizontal hydraulic conductivity and transmissivity values for the Yorktown-Eastover aquifer, determined from slug tests

[Transmissivity not determined for unconfined aquifers, $\mathrm{U}$; transmissivity could not be determined from available data, I; unavailable data, ---; for locations of observation wells see figure 2]

\begin{tabular}{|c|c|c|}
\hline Well number & $\begin{array}{c}\text { Horizontal } \\
\text { hydraulic } \\
\text { conductivity } \\
\text { (feet per day) }\end{array}$ & $\begin{array}{c}\text { Transmissivity }{ }^{2} \\
\text { (feet squared } \\
\text { per day) }\end{array}$ \\
\hline $58 \mathrm{~F} 70$ & $.3^{(3)}$ & -- \\
\hline 58 F79 &..$^{(3)}$ & --- \\
\hline $58 \mathrm{~F} 98$ & .05 & 4 \\
\hline 58 F99 & .5 & 20 \\
\hline $58 \mathrm{~F} 103$ & .08 & 6 \\
\hline $58 \mathrm{~F} 104$ & .2 & 4 \\
\hline $58 \mathrm{~F} 108$ & .03 & .5 \\
\hline $58 \mathrm{~F} 109$ & .3 & 6 \\
\hline $58 \mathrm{~F} 113$ & .02 & .9 \\
\hline $58 \mathrm{~F} 114$ & .2 & 4 \\
\hline $58 \mathrm{~F} 118$ & .02 & I \\
\hline $58 \mathrm{~F} 119$ & .4 & 40 \\
\hline $58 \mathrm{G} 48$ & $.03^{(3)}$ & -- \\
\hline $58 \mathrm{G} 50$ & .004 & $\mathrm{U}$ \\
\hline $58 \mathrm{G} 51$ & .3 & $\mathbf{U}$ \\
\hline $\begin{array}{l}{ }^{1} \text { Calculated by } \\
{ }^{2} \text { Calculated by } \\
{ }^{3} \text { Rounded to } 0 \\
\text { and Roy F. We }\end{array}$ & $\begin{array}{l}\mathrm{d} \text { in Bouwer, } 19 \\
\mathrm{~d} \text { in Cooper and } \\
\text { ificant figure fro } \\
\text { c., } 1993 \text {. }\end{array}$ & $\begin{array}{l}1967 . \\
\text { er Environmental, }\end{array}$ \\
\hline
\end{tabular}




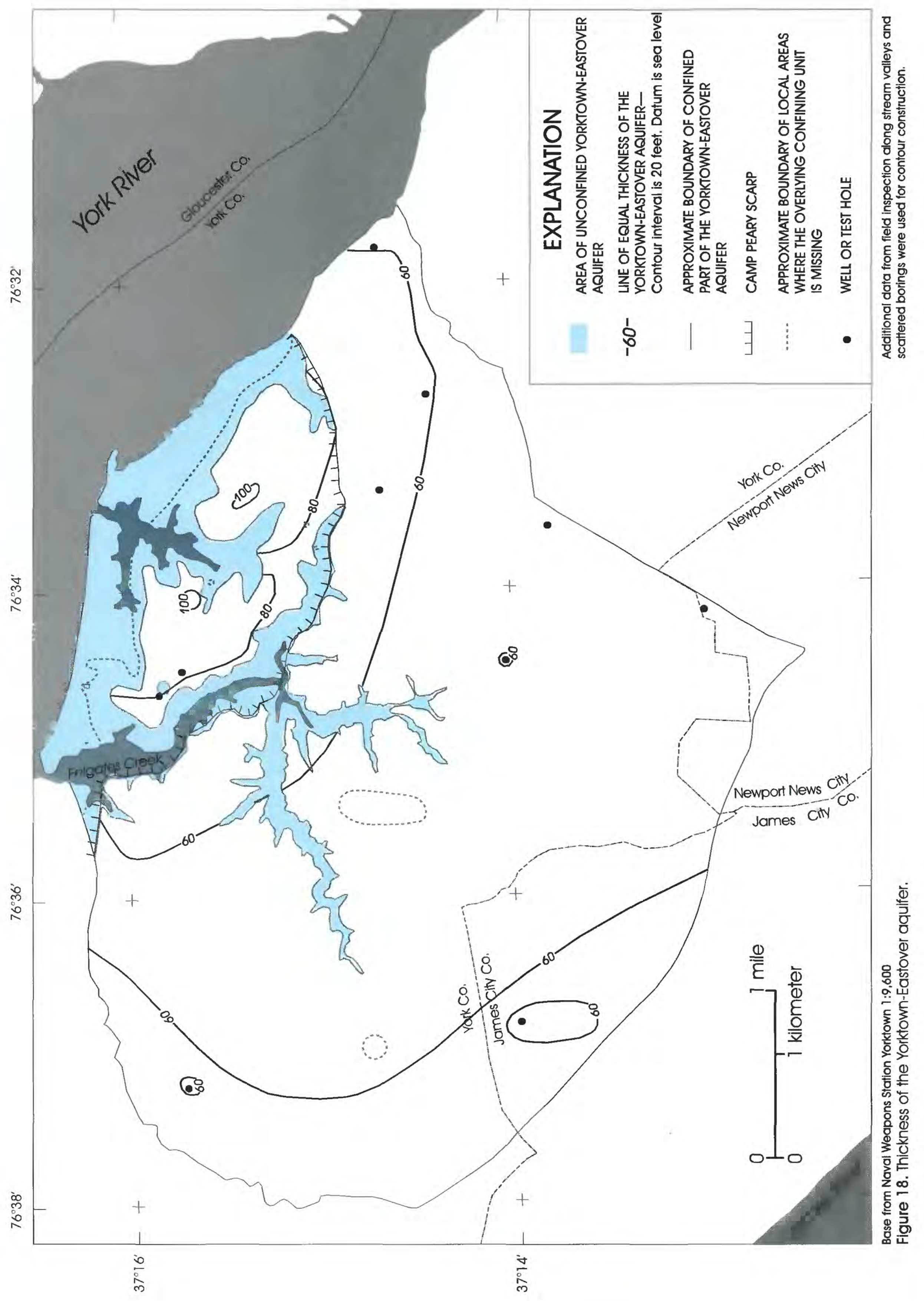


Table 9. Vertical hydraulic conductivity values for the Yorktown-Eastover aquifer and the underlying Eastover-Calvert confining unit, determined from vertical permeameter tests ${ }^{1}$

[For locations of observation wells see figure 2]

\begin{tabular}{|c|c|c|c|c|c|}
\hline $\begin{array}{c}\text { Well } \\
\text { number }\end{array}$ & & $\begin{array}{r}\text { Altitu } \\
\text { inter } \\
\text { (fee }\end{array}$ & & $\begin{array}{c}\text { Geohydrologic } \\
\text { unit }\end{array}$ & $\begin{array}{c}\text { Vertical hydraulic } \\
\text { conductivity } \\
\text { (feet per day) }\end{array}$ \\
\hline $58 \mathrm{~F} 98$ & -36.5 & to & -38.5 & Yorktown-Eastover aquifer & $7.1 \times 10^{-2}$ \\
\hline $58 \mathrm{~F} 103$ & -2.5 & to & -4 & Yorktown-Eastover aquifer & $1.7 \times 10^{-3}$ \\
\hline $58 \mathrm{~F} 103$ & -37.5 & to & -38.5 & Yorktown-Eastover aquifer & $4.3 \times 10^{-3}$ \\
\hline $58 \mathrm{~F} 108$ & 4.5 & to & 2.5 & Yorktown-Eastover aquifer & $7.1 \times 10^{-3}$ \\
\hline $58 \mathrm{~F} 108$ & -36.5 & to & -38.5 & Yorktown-Eastover aquifer & $9.9 \times 10^{-4}$ \\
\hline $58 \mathrm{~F} 113$ & -32 & to & -34 & Yorktown-Eastover aquifer & $1.7 \times 10^{-5}$ \\
\hline $58 \mathrm{~F} 114$ & -2 & to & -3 & Yorktown-Eastover aquifer & $1.0 \times 10^{-2}$ \\
\hline $58 \mathrm{~F} 118$ & -23.5 & to & -24.5 & Yorktown-Eastover aquifer & $6.2 \times 10^{-2}$ \\
\hline $58 \mathrm{~F} 118$ & -43.5 & to & -45 & Yorktown-Eastover aquifer & $1.9 \times 10^{-2}$ \\
\hline $58 \mathrm{~F} 118$ & -53.5 & to & -54.5 & Yorktown-Eastover aquifer & $1.3 \times 10^{-3}$ \\
\hline $58 \mathrm{G} 50$ & 12.5 & to & 11.5 & Yorktown-Eastover aquifer & $4.8 \times 10^{-1}$ \\
\hline $58 \mathrm{G} 50$ & 3.5 & to & 1.5 & Yorktown-Eastover aquifer & $4.5 \times 10^{-2}$ \\
\hline $58 \mathrm{G} 50$ & -23.5 & to & -25 & Yorktown-Eastover aquifer & $1.1 \times 10^{-3}$ \\
\hline $58 \mathrm{G} 50$ & -38.5 & to & -40 & Yorktown-Eastover aquifer & $2.0 \times 10^{-2}$ \\
\hline $58 \mathrm{G} 50$ & -48.5 & to & -50 & Yorktown-Eastover aquifer & $6.8 \times 10^{-3}$ \\
\hline $58 \mathrm{G} 50$ & -66.5 & to & -68.5 & Yorktown-Eastover aquifer & $1.1 \times 10^{-3}$ \\
\hline $58 \mathrm{G} 51$ & 16.5 & to & 15 & Yorktown-Eastover aquifer & $1.8 \times 10^{-3}$ \\
\hline $58 \mathrm{G} 51$ & -2.5 & to & -4.5 & Yorktown-Eastover aquifer & $8.8 \times 10^{-2}$ \\
\hline $58 \mathrm{G} 55$ & -51 & to & -53 & Yorktown-Eastover aquifer & $6.0 \times 10^{-4}$ \\
\hline $58 \mathrm{G} 55$ & -14 & to & -16 & Yorktown-Eastover aquifer & $1.8 \times 10^{-2}$ \\
\hline $58 \mathrm{G} 55$ & -36 & to & -38 & Yorktown-Eastover aquifer & $2.5 \times 10^{-4}$ \\
\hline $58 \mathrm{G} 61$ & -40.5 & to & -41.5 & Yorktown-Eastover aquifer & $7.4 \times 10^{-4}$ \\
\hline $58 \mathrm{G} 62$ & -40 & to & -42 & Yorktown-Eastover aquifer & $3.7 \times 10^{-2}$ \\
\hline $58 \mathrm{~F} 98$ & -47.5 & to & -49.5 & clay in Yorktown-Eastover aquifer & $1.3 \times 10^{-3}$ \\
\hline $58 \mathrm{~F} 103$ & -14.5 & to & -16 & clay in Yorktown-Eastover aquifer & $4.0 \times 10^{-6}$ \\
\hline $58 \mathrm{~F} 108$ & -7.5 & to & -9 & clay in Yorktown-Eastover aquifer & $2.0 \times 10^{-5}$ \\
\hline $58 \mathrm{~F} 113$ & -14 & to & -16 & clay in Yorktown-Eastover aquifer & $1.4 \times 10^{-5}$ \\
\hline $58 \mathrm{~F} 102$ & -92.5 & to & -94.5 & Eastover-Calvert confining unit & $8.5 \times 10^{-5}$ \\
\hline $58 \mathrm{~F} 103$ & -46.5 & to & -48.5 & Eastover-Calvert confining unit & $1.2 \times 10^{-4}$ \\
\hline $58 \mathrm{~F} 112$ & -64.5 & to & -66.5 & Eastover-Calvert confining unit & $4.5 \times 10^{-5}$ \\
\hline $58 \mathrm{~F} 117$ & -67 & to & -69 & Eastover-Calvert confining unit & $1.7 \times 10^{-4}$ \\
\hline $58 \mathrm{~F} 122$ & -78.5 & to & -80.5 & Eastover-Calvert confining unit & $6.0 \times 10^{-6}$ \\
\hline $58 \mathrm{~F} 124$ & -91.5 & to & -93.5 & Eastover-Calvert confining unit & $3.7 \times 10^{-4}$ \\
\hline $58 \mathrm{G} 54$ & -105.5 & to & -107.5 & Eastover-Calvert confining unit & $3.4 \times 10^{-5}$ \\
\hline $58 \mathrm{G} 59$ & -71 & to & -73 & Eastover-Calvert confining unit & $4.8 \times 10^{-5}$ \\
\hline $58 \mathrm{G} 60$ & -85.5 & to & -87.5 & Eastover-Calvert confining unit & $1.9 \times 10^{-4}$ \\
\hline $58 \mathrm{G} 61$ & -90.5 & to & -92.6 & Eastover-Calvert confining unit & $2.3 \times 10^{-5}$ \\
\hline $58 \mathrm{G} 62$ & -90 & to & -92 & Eastover-Calvert confining unit & $4.3 \times 10^{-4}$ \\
\hline
\end{tabular}

\footnotetext{
'Vertical permeameter tests conducted by U.S. Army Corps of Engineers, Ohio River Division Laboratory, unpub. data, 1996.
} 


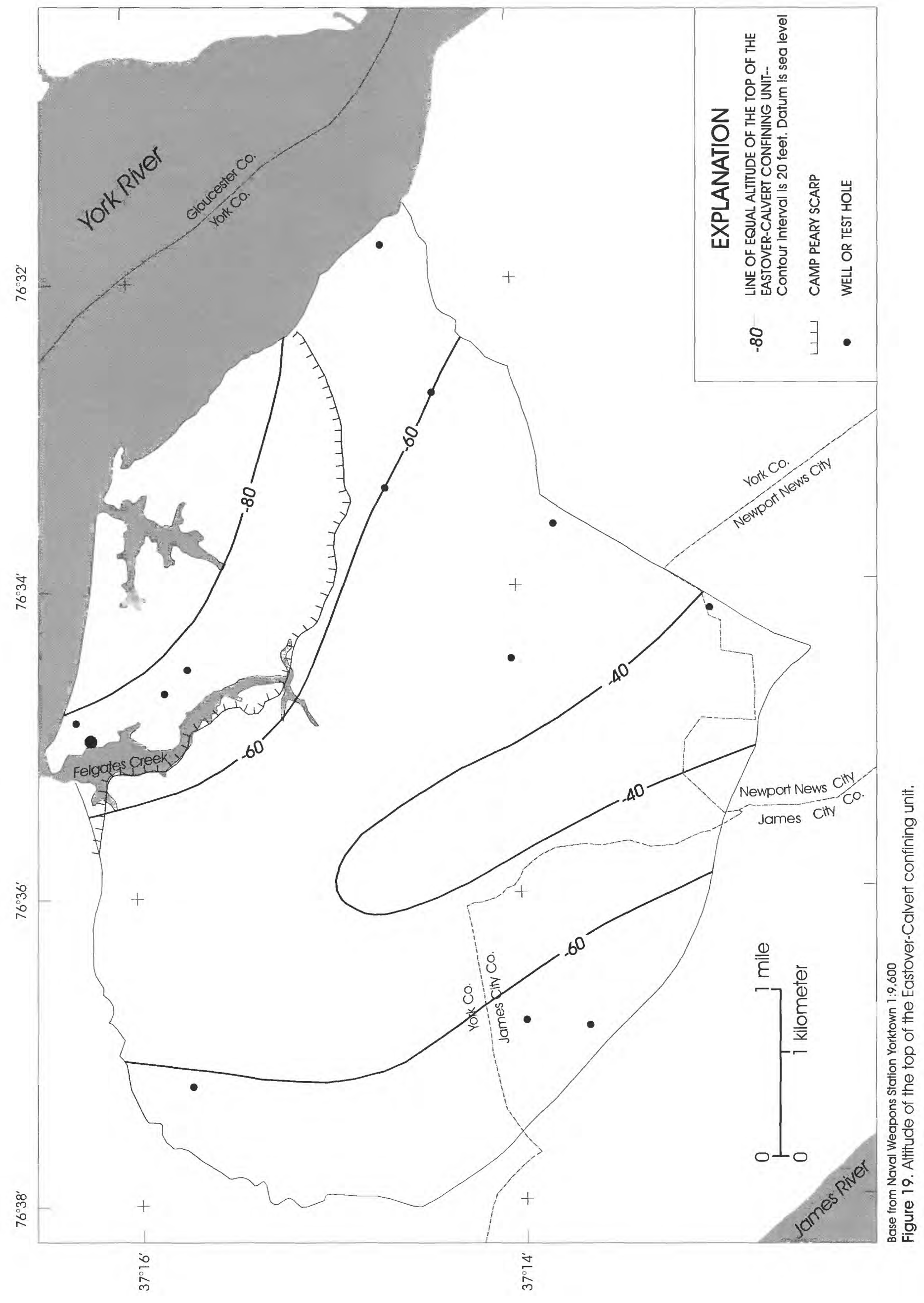




\section{Eastover-Calvert Confining Unit}

The Eastover-Calvert confining unit at the Station is defined in Brockman and Richardson (1992) as follows: The silt, clay, and fine-grained sand sediments of the Calvert and St. Marys Formations and the Claremont Manor Member of the Eastover Formation. Clayey silt, silty clay, sandy clay, some sand lenses, and some shell hash also are common in this unit at the Station. The top of the Eastover-Calvert confining unit defines the base of the shallow aquifer system at the Station. Bulk x-ray mineralogy of 11 Shelby-tube samples shows that confining unit sediments from across the Station consist of 90 percent quartz; 1.5 percent illite, glauconite, or mica; 1 percent pyrite; and minor amounts of calcite, plagioclase, orthoclase, chlorite, and (or) lepidocrocite (U.S. Army Corps of Engineers, Ohio River Division Laboratory, unpub. data, 1996).

The altitude of the top of the confining unit is highest ( $40 \mathrm{ft}$ below sea level) along a rise trending northwest from the southern tip of the Station toward the western watershed of Felgates Creek (fig. 19). The lowest altitude for the confining unit top is more than $80 \mathrm{ft}$ below sea level along the York River estuary (fig. 19). The maximum confining unit thickness is more than $166 \mathrm{ft}$ at the eastern Station boundary (58F102); and the minimum thickness is $140 \mathrm{ft}$ at the southwestern boundary (58F160, table 2). The confining unit thickness was not contoured as a result of sparse data, but the unit generally is more than $150 \mathrm{ft}$ thick across the Station (table 2). The confining unit is present throughout the Station.

The Eastover-Calvert confining unit impedes the vertical flow of ground water between the YorktownEastover and deeper Coastal Plain aquifers at the Station, as vertical hydraulic conductivities indicate. Vertical permeameter tests were done on 11 samples of the EastoverCalvert confining unit (table 9). Vertical hydraulic conductivities range from $6.0 \times 10^{-6} \mathrm{ft} / \mathrm{d}$ to $4.3 \times 10^{-4} \mathrm{ft} / \mathrm{d}$.

\section{Conceptualized Ground-Water Flow}

Maps and geohydrologic framework diagrams provide a detailed description of the separate components of the ground-water-flow system at the Naval Weapons Station Yorktown, but a knowledge of water fluctuation through time and the interaction between the system components are essential to understanding the geohydrology of a dynamic system. This section presents a descrip- tion of ground-water fluctuation followed by an interpretation of the aggregated shallow ground-waterflow system at the Station.

\section{Ground-Water Fluctuation}

Hydrologic conditions affecting water-level fluctuations at the Station include variations in rainfall and evapotranspiration, geohydrologic setting, tidal fluctuation, and human activity. The relation between rainfall and rising ground-water levels is complex because of rainfall-related factors, such as intensity, duration, surface runoff, soil moisture, vertical percolation rate, barometric pressure changes, and air entrapment pressure. Rising water level in a well during and following rainfall events results from a combination of these factors, as further explained in Freeze and Cherry (1979) and Todd (1980).

Evapotranspiration is a mode of ground-water discharge to the atmosphere that causes declines in water levels (Todd, 1980). Evapotranspiration components are evaporation and plant transpiration, both of which are driven by temperature and sunlight. The evapotranspiration process follows diurnal and seasonal cycles resulting from diurnal and seasonal changes in temperature and plant growth (Todd, 1980).

The geohydrologic setting within the groundwater-flow system at the Station is an important factor in the altitude and fluctuations of water levels. Continuous monitoring of water levels not only provides information on the magnitude of ground-water fluctuations, but it is an integral process in the delineation of geohydrologic units. Analysis of water-level data at well clusters across the Station (fig. 20) and definition of the geohydrologic units indicates that two primary geohydrologic settings typically occur at the Station: (1) recharge areas where sediments of the Columbia, Cornwallis Cave, and Yorktown-Eastover aquifers are saturated, and (2) discharge areas where sediments of the Columbia aquifer are unsaturated, but sediments of the Cornwallis Cave and Yorktown-Eastover aquifers are saturated. The Cornwallis Cave aquifer may not be present in either of these settings, where it is missing along an unconformity beneath Croaker flat.

Primary recharge areas, scattered about at higher elevations of the Station and across Croaker flat, are characterized by saturated sediments in the Columbia and Yorktown-Eastover aquifers, and where present, the Cornwallis Cave aquifer. The Columbia aquifer is unconfined, but the Cornwallis Cave and Yorktown-Eastover 


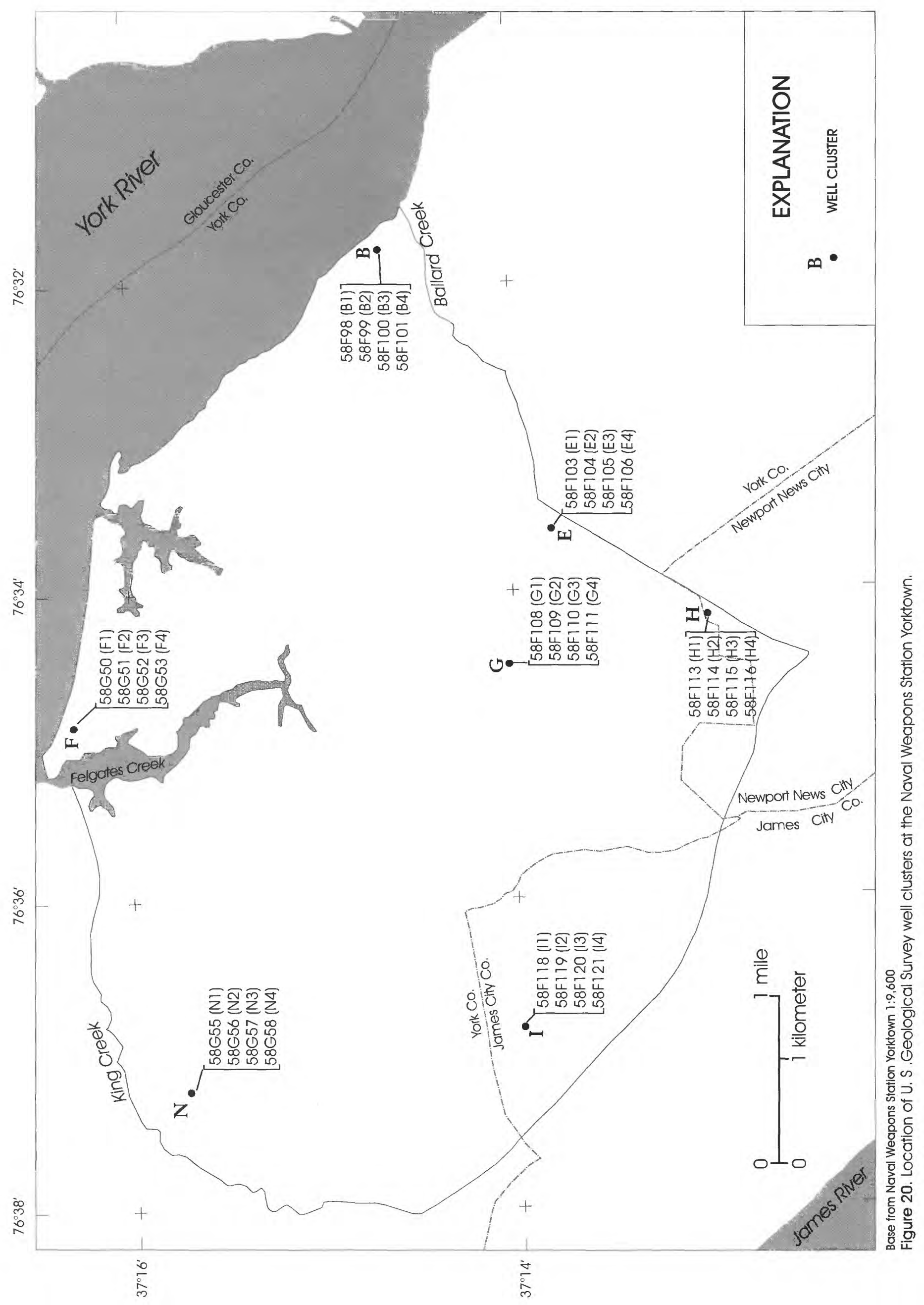


aquifers generally are under confined conditions. Waterlevel fluctuations are pronounced in the Columbia aquifer and become progressively more subdued in the deeper aquifers (fig. 21). The large rises in water levels in the Columbia aquifer wells (58F106 and 58F121) during the late summer and early autumn months probably are more a response to air entrapment pressures in the unsaturated zone than to actual recharge events (Freeze and Cherry, 1979; Todd, 1980). The slight differences in water-level altitudes in the Yorktown-Eastover aquifer wells $(58 \mathrm{~F} 103,58 \mathrm{~F} 104,58 \mathrm{~F} 118$, and $58 \mathrm{~F} 119)$ indicate that the horizontal component of flow within this aquifer probably is greater than the vertical component.

Vertical head gradients between aquifers are generally high in recharge areas and ground-water flow is directed downward; for example, the vertical head gradients between the aquifers are downward at both clusters I and $\mathrm{E}$ (fig. 21). The vertical gradient is greater at cluster I than at cluster E. Cluster I is located at or near a groundwater divide (recharge area), whereas cluster $\mathrm{E}$ is located in a setting further downgradient.

Ground-water temperature fluctuations tend to follow the same pattern as water-level fluctuations. Daily mean water temperatures, measured by down-hole sensors, in wells in the Columbia aquifer are more seasonally influenced (greater variation) than those in the deeper aquifers. Water temperature in the Columbia aquifer is highest in the late autumn and early winter months; whereas slightly higher temperatures in the deeper aquifers generally occur in the late winter and early spring months. This apparent seasonal lag probably is a reflection of the slow downward transfer of heat in the earth and in ground water.

In discharge areas at the Station, the sediments of the Columbia aquifer are unsaturated, the unsaturated zone is generally thick, the Cornwallis Cave aquifer is saturated and unconfined, and the Yorktown-Eastover aquifer is under confined conditions. In discharge areas beneath the Croaker flat, the Columbia aquifer sediments are unsaturated, the Cornwallis Cave aquifer is missing, and the Yorktown-Eastover aquifer is saturated and unconfined. Water-level fluctuations in the unconfined Cornwallis Cave aquifer ( $58 \mathrm{~F} 100$ and $58 \mathrm{~F} 110)$ generally are not as pronounced as in recharge settings (fig. 22).

Vertical head gradients between aquifers are generally low in discharge areas and ground-water flow direction can be either downward or upward. Ground-water flow is directed toward the discharge areas (seeps, springs, streams, and estuaries); for example, the vertical head gradient is downward at cluster B (fig. 22A), in a discharge area adjacent to the York River. The vertical head gradient is upward at cluster G (fig. 22B), in a discharge area adjacent to a tributary of Felgates Creek. The direction of the vertical gradient probably is a function of the relative position of the ground-water-discharge point or area to the general geometry of the ground-water-flow system at a specific location. Numerical modeling could be used to indicate the nature of the relation between vertical gradients and discharge areas at the Station. Variations in ground-water temperature generally are less than $1^{\circ} \mathrm{C}$; but, unlike the areas where the Columbia aquifer is saturated, the maximum water temperatures occur in the late winter and early spring months (fig. 22).

A unique discharge setting is present where the Yorktown-Eastover aquifer is unconfined and both the Columbia and Cornwallis Cave aquifers are missing along the York River (figs. 15, 16, and 18, wells 58G50 through 58G54). Similar water-level altitudes, response to rainfall events, and seasonal fluctuations in wells 58G50, 58G51, and 58G52 indicate that the entire shallow aquifer system is connected and acts as an extremely thick unconfined aquifer (fig. 23). Generally uniform vertical hydraulic conductivities throughout this unit (wells 58G50 and 58G51, table 9) support this conclusion. This unique setting is comparable to the York County shallow aquifer system (undivided) unit described in Brockman and Richardson (1992, p. 9). Variations in ground-water temperature generally are less than $1{ }^{\circ} \mathrm{C}$. The occurrence of minimum and maximum water temperatures in the deeper parts of the aquifer tends to lag behind the shallower parts by approximately 3 to 4 months.

Semidiurnal tides in the York River estuary induce nearshore fluctuation in ground-water levels at the Station. Tidal oscillations, which are in response to estuarine loading of the overlying geohydrologic units during tidal surges at the surface (Todd, 1980, p. 245), only were recorded in wells completed in the Yorktown-Eastover aquifer (58F98, 58F99, and 58G51). Typical water-level fluctuations in response to tidal oscillations for wells $58 \mathrm{~F} 98,58 \mathrm{~F} 99$, and 58G51 are shown in figure 24. Fluctuation of ground-water levels in response to tides diminishes with distance inland at the Station, and no tidal fluctuation is observed at the other USGS well clusters on the Station.

No anthropogenic stresses such as those caused by pumped wells, injection wells, or other recharge sources (like leaking structures) are currently known at the Station or in the immediate vicinity. The introduction of 


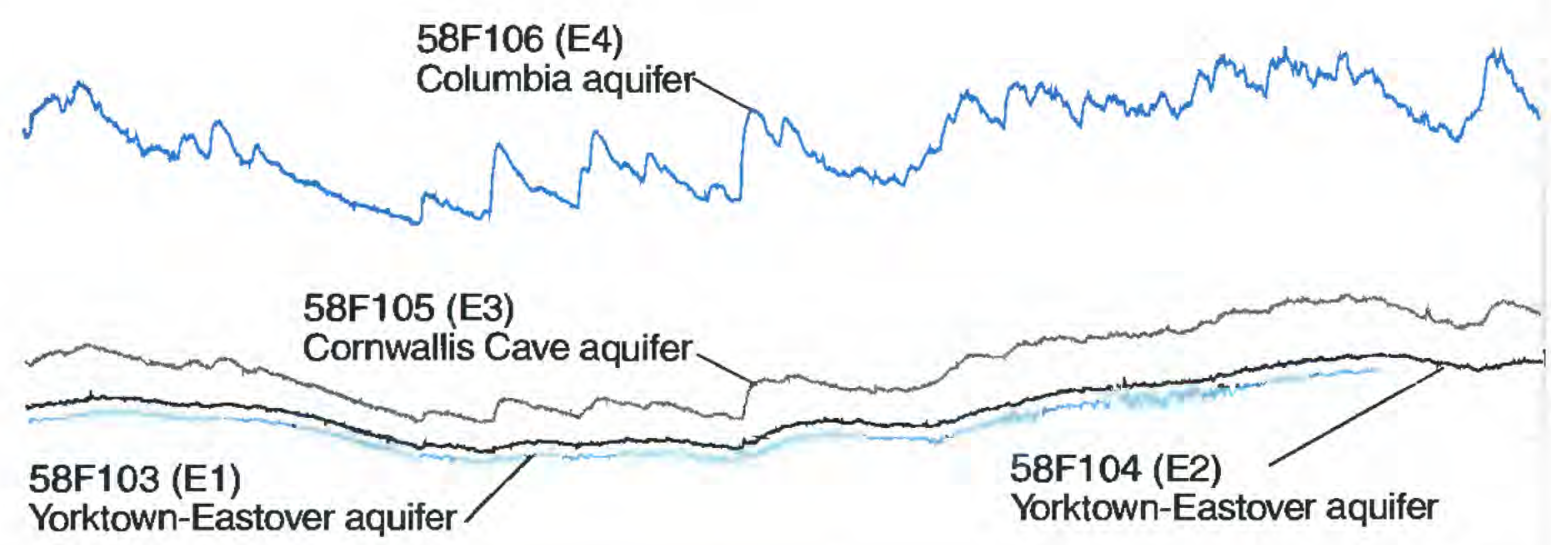

55

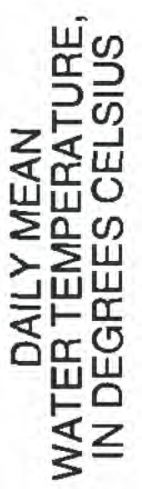

18

GAPS INDICATE MISSING DATA

16

14

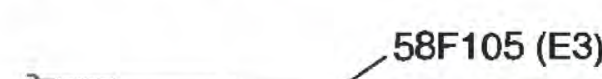

12

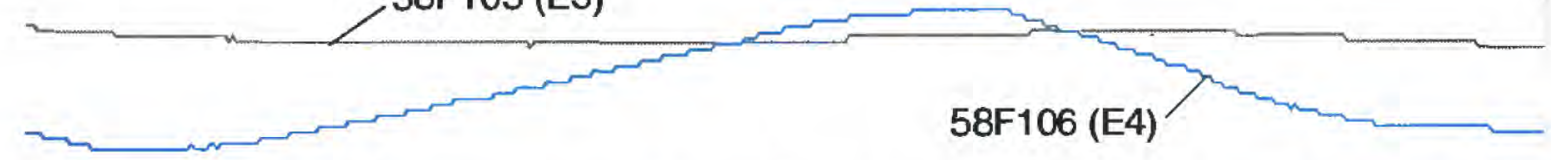

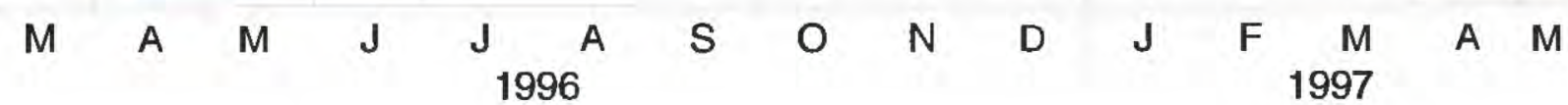

90

GAPS INDICATE MISSING DATA

(B) CLUSTER I

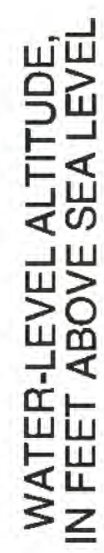

85

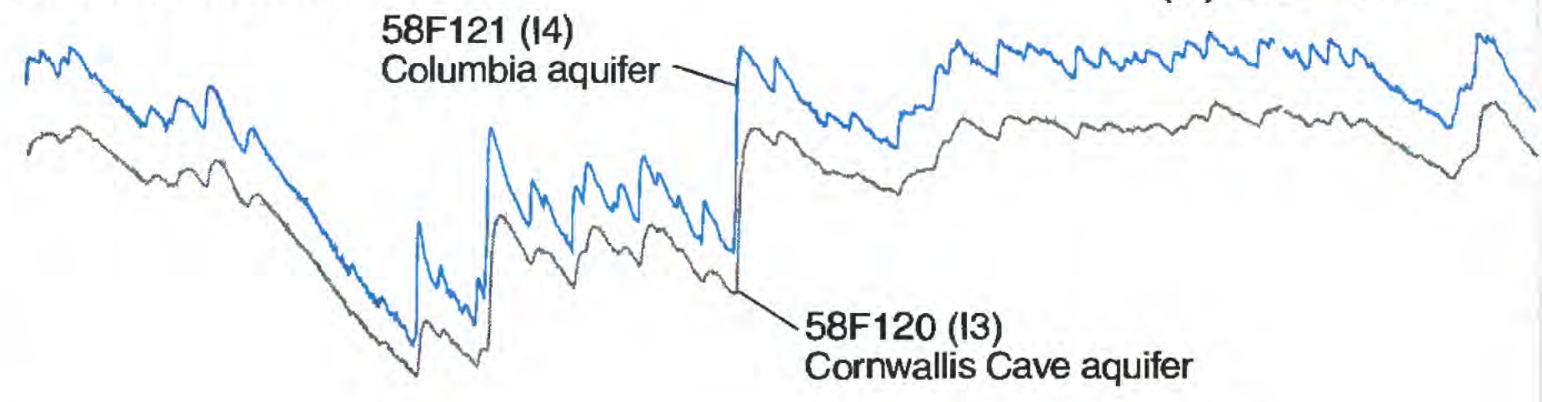

70

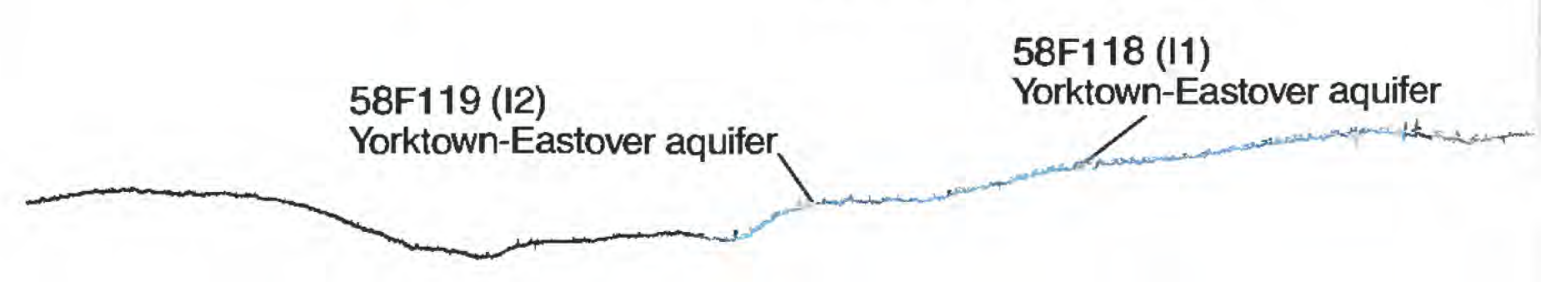

60

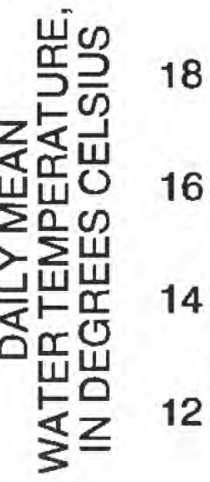

GAPS INDICATE MISSING DATA

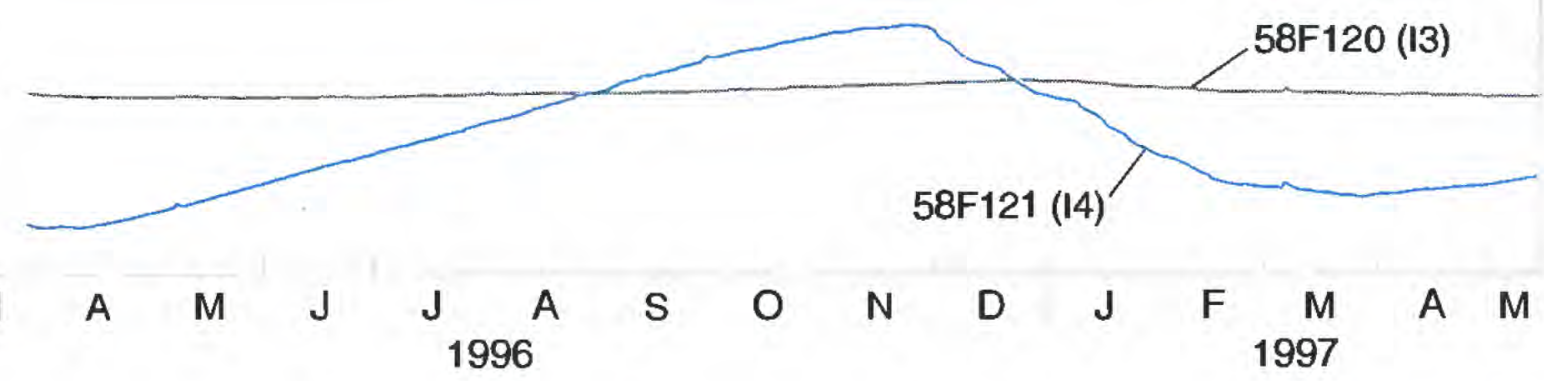

Figure 21. Water levels and daily mean water temperatures at well clusters $E(A)$ and I (B), Naval Weapons Station Yorktown. 


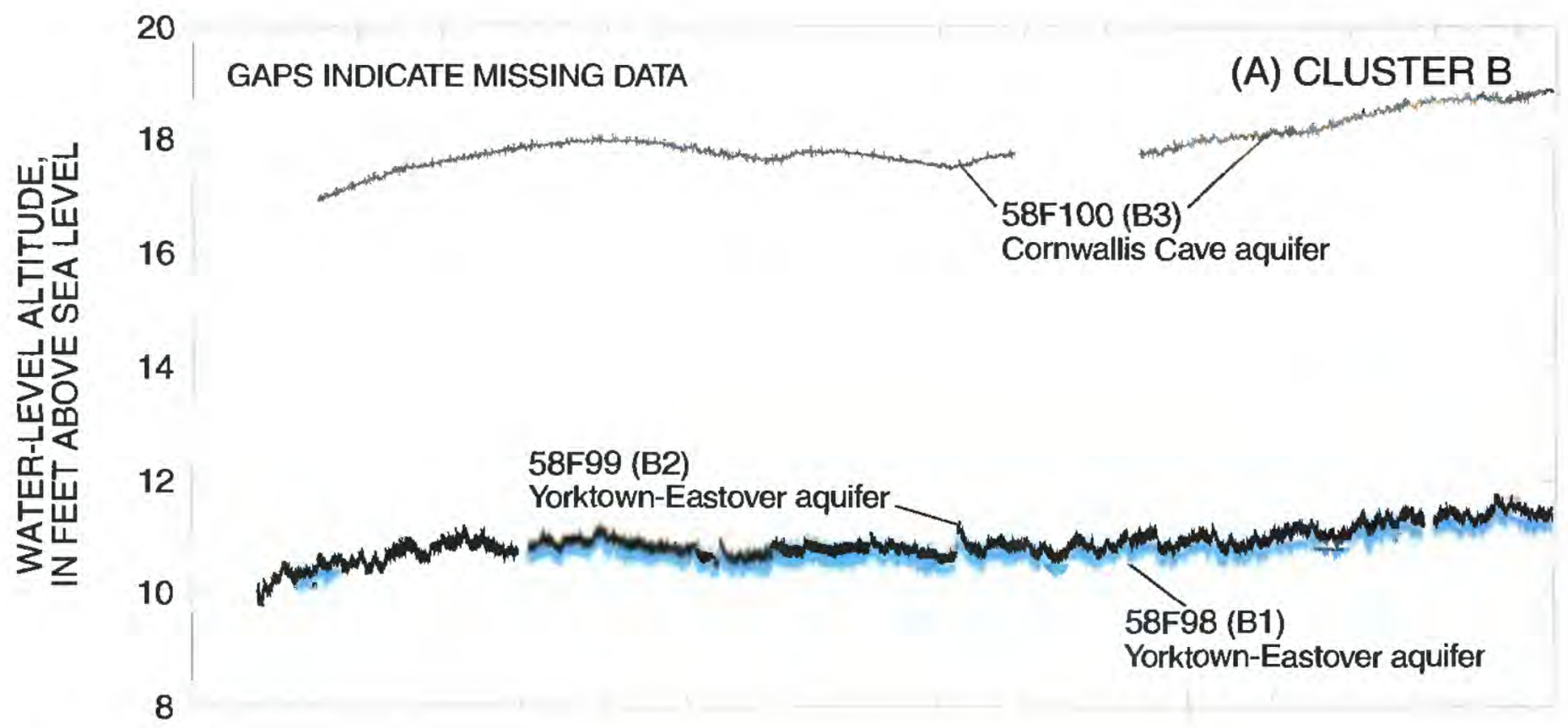

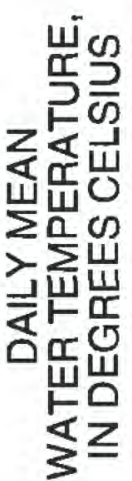

15.5

GAPS INDICATE MISSING DATA

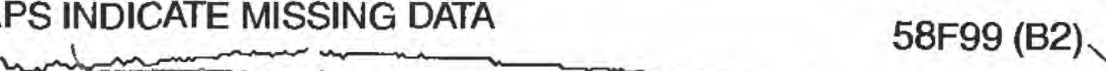

15.0

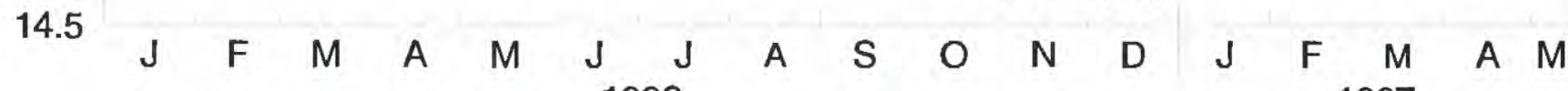

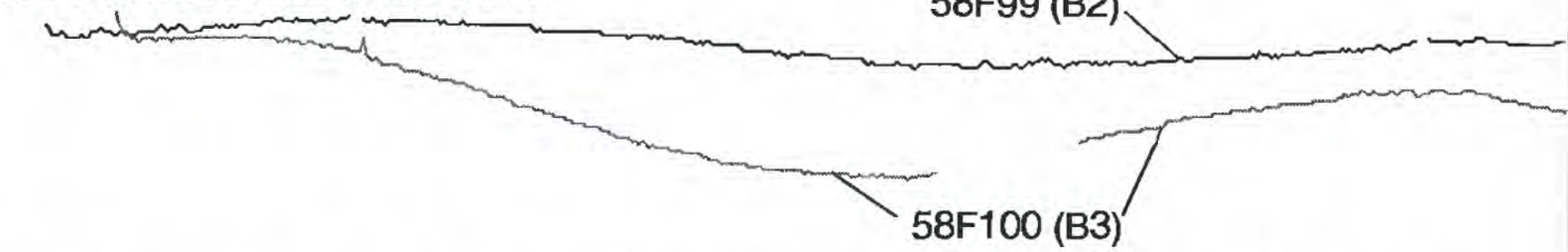

42

GAPS INDICATE MISSING DATA

(B) CLUSTER G

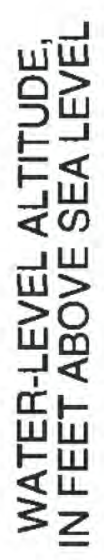

40

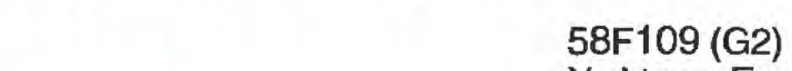

$58 \mathrm{~F} 109$ (G2)

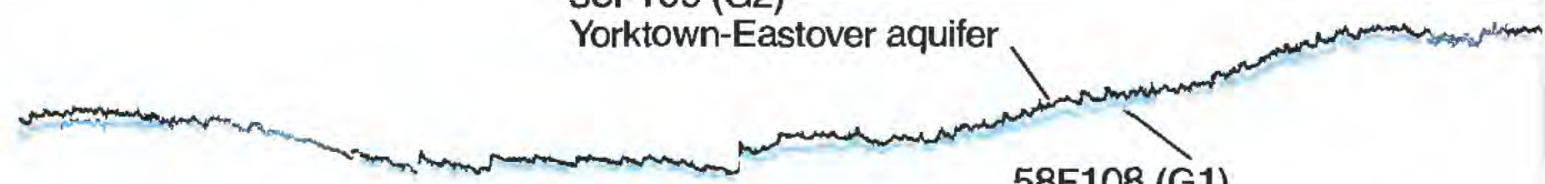

38

58F108 (G1)

Yorktown-Eastover aquifer

36

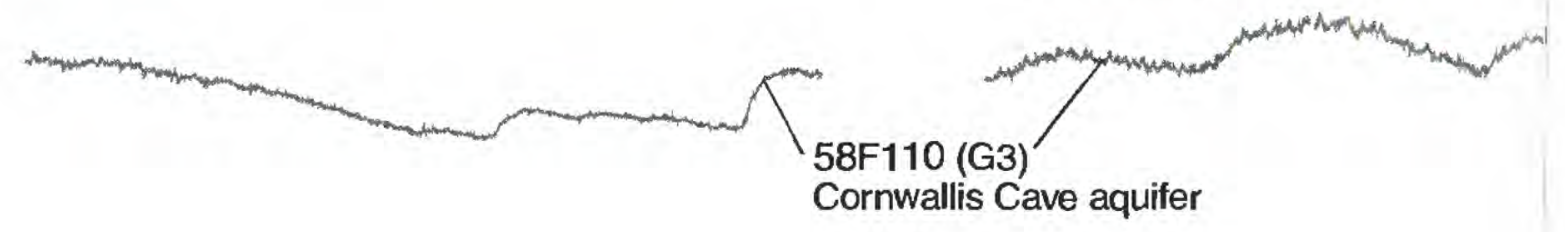

32

30

㞻吅

17.0

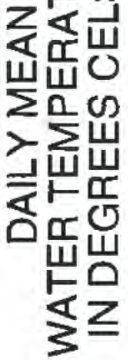

17.0

GAPS INDICATE MISSING DATA

16.5

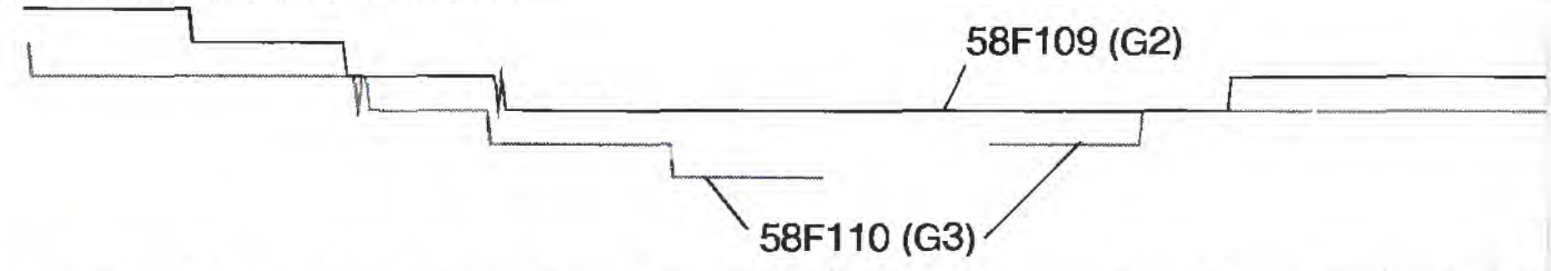

16.0

$\begin{array}{llllllllllllll}M & A & M & J & J \underset{1996}{A} & S & O & N & D & J & F \underset{1997}{M} & A & M\end{array}$

Figure 22. Water levels and daily mean water temperatures at well clusters $B(A)$ and G (B), Naval Weapons Station Yorktown. 


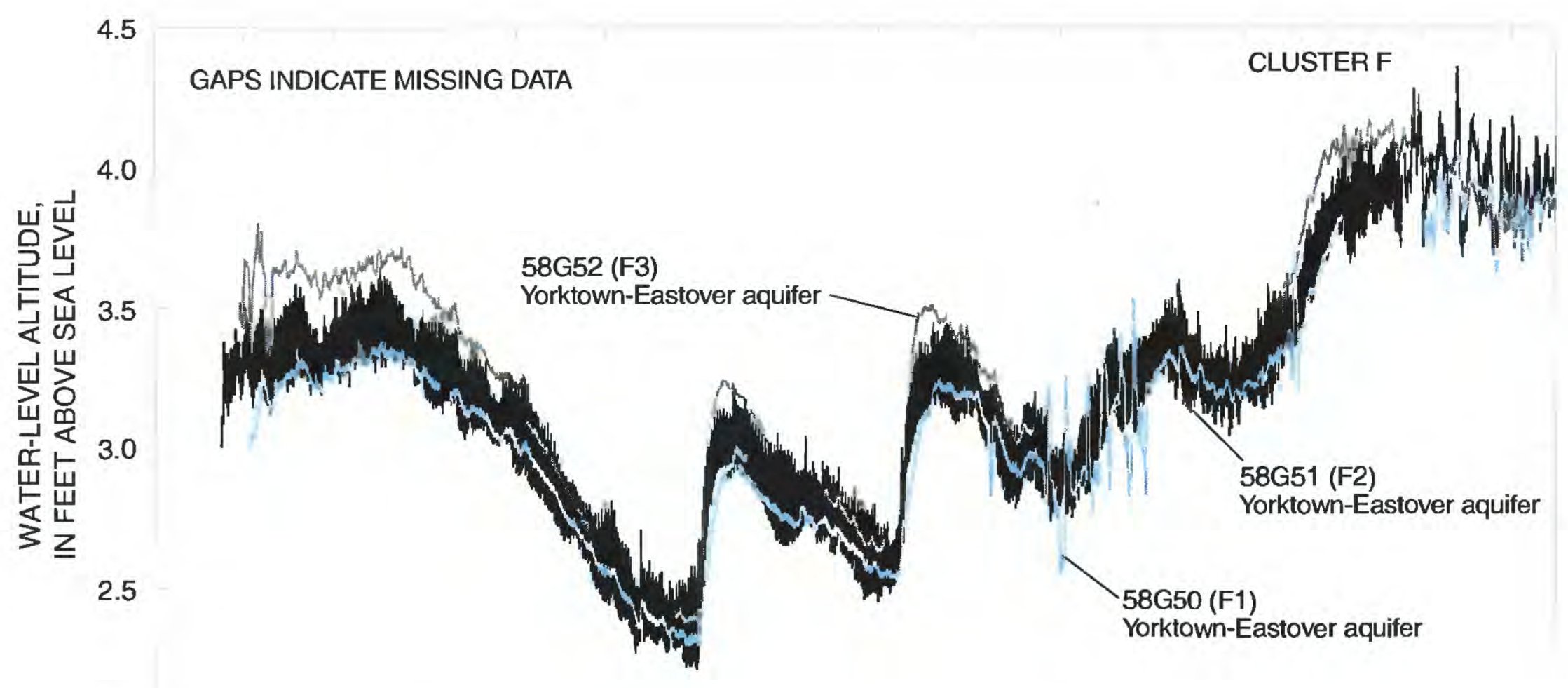

2.0

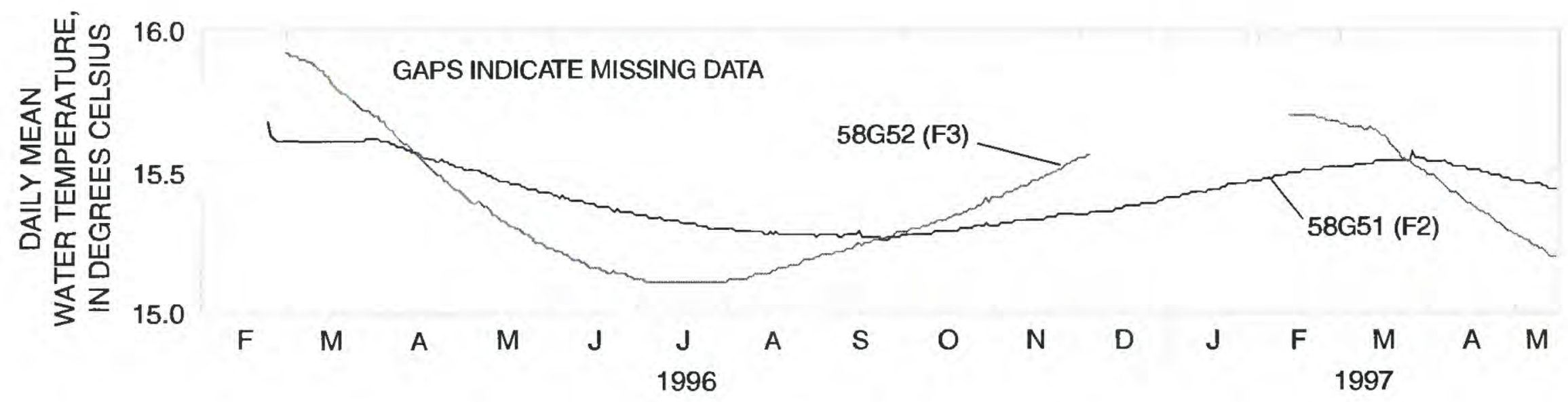

Figure 23. Water levels and daily mean water temperatures at well cluster F, Naval Weapons Station Yorktown.

such stresses at the Station or in the adjacent area could result in future changes in ground-water fluctuation and thus changes in ground-water gradients.

\section{Ground-Water-Flow System}

The shallow ground-water-flow system at the Station consists of the Columbia, Cornwallis Cave, and Yorktown-Eastover aquifers (fig. 25). The system is recharged directly by rainfall or indirectly from rainfall by leakage through the Cornwallis Cave and Yorktown confining units. Preliminary results of young ages (30 years or less) from ground-water dating at the Station in early 1997 indicate that most of the recharge originates from either the Station or the nearby adjacent area (David Nelms, U.S. Geological Survey, unpub. data, 1997). Some of the ground water is recharged on higher terraces to the northwest, flowing tens of miles before reaching the Station vicinity (Laczniak and Meng, 1988). The system discharges to the York River and the James River estuaries and their tributaries.

\section{Columbia Aquifer}

The Columbia aquifer extent generally is contiguous to the recharge area extent at the Station. The Columbia aquifer is divided into discontinuous pods or lenses scattered about the higher elevations of the Station and across the Croaker flat, along stream divides (sections, pl. 1). Many of the Columbia aquifer pods are assumed to be in hydraulic contact with upland wetland areas, which appear to fluctuate in size in response to rainfall and evapotranspiration rate. 


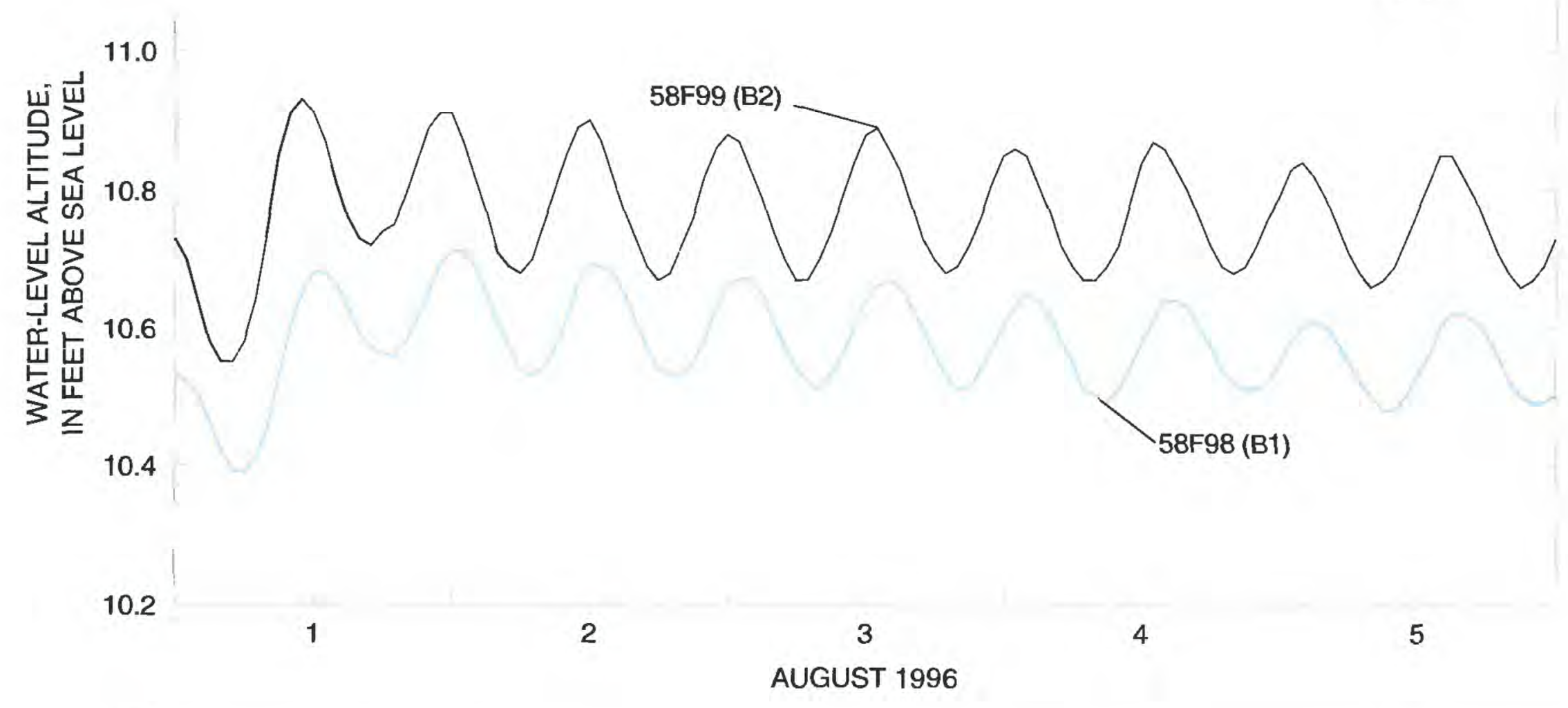

3.2

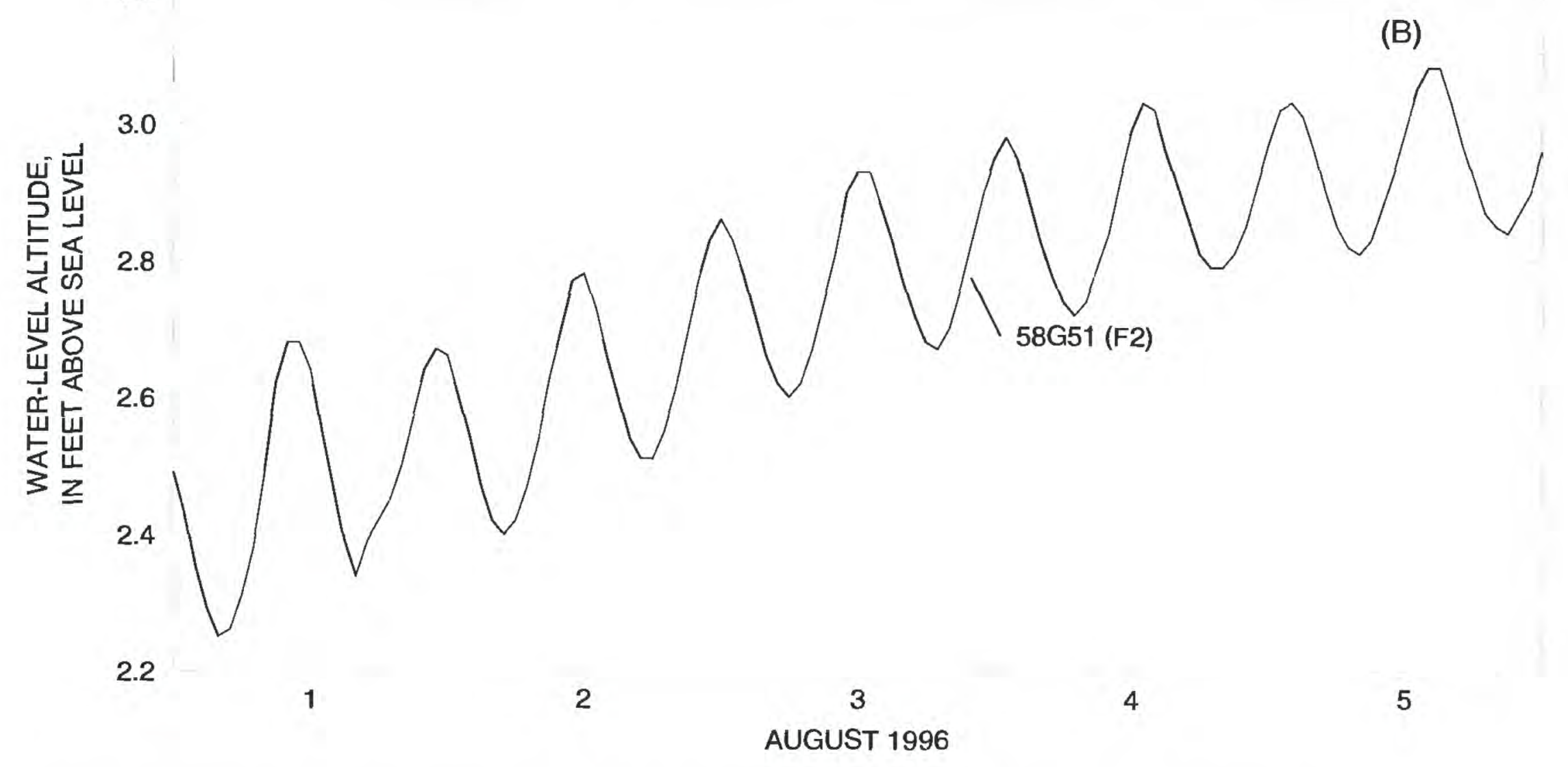

Figure 24. Water levels and response to tidal fluctuations in the York River estuary in wells $58 \mathrm{~F} 98$ and 58 F99 (A) and in well $58 \mathrm{G} 51$ (B) at the Naval Weapons Station Yorktown.

Vertical hydraulic conductivities in the two upper confining units range from a low of $1.3 \times 10^{-5} \mathrm{ft} / \mathrm{d}$ in the Yorktown confining unit to a high of $1.4 \times 10^{-2} \mathrm{ft} / \mathrm{d}$ in the Cornwallis Cave confining unit (tables 5 and 7). Vertical hydraulic conductivities for sands in all of the aquifers are comparable in range to those of the confining units, from a low of $1.7 \times 10^{-5} \mathrm{ft} / \mathrm{d}$ in the Yorktown-Eastover aquifer to a high of $4.8 \times 10^{-1} \mathrm{ft} / \mathrm{d}$ in the same aquifer (table 9). Compounded with the similarity in vertical hydraulic conductivities between the aquifers and the upper confining units are limited confining-unit thicknesses (generally $8 \mathrm{ft}$ for the Cornwallis Cave confining 


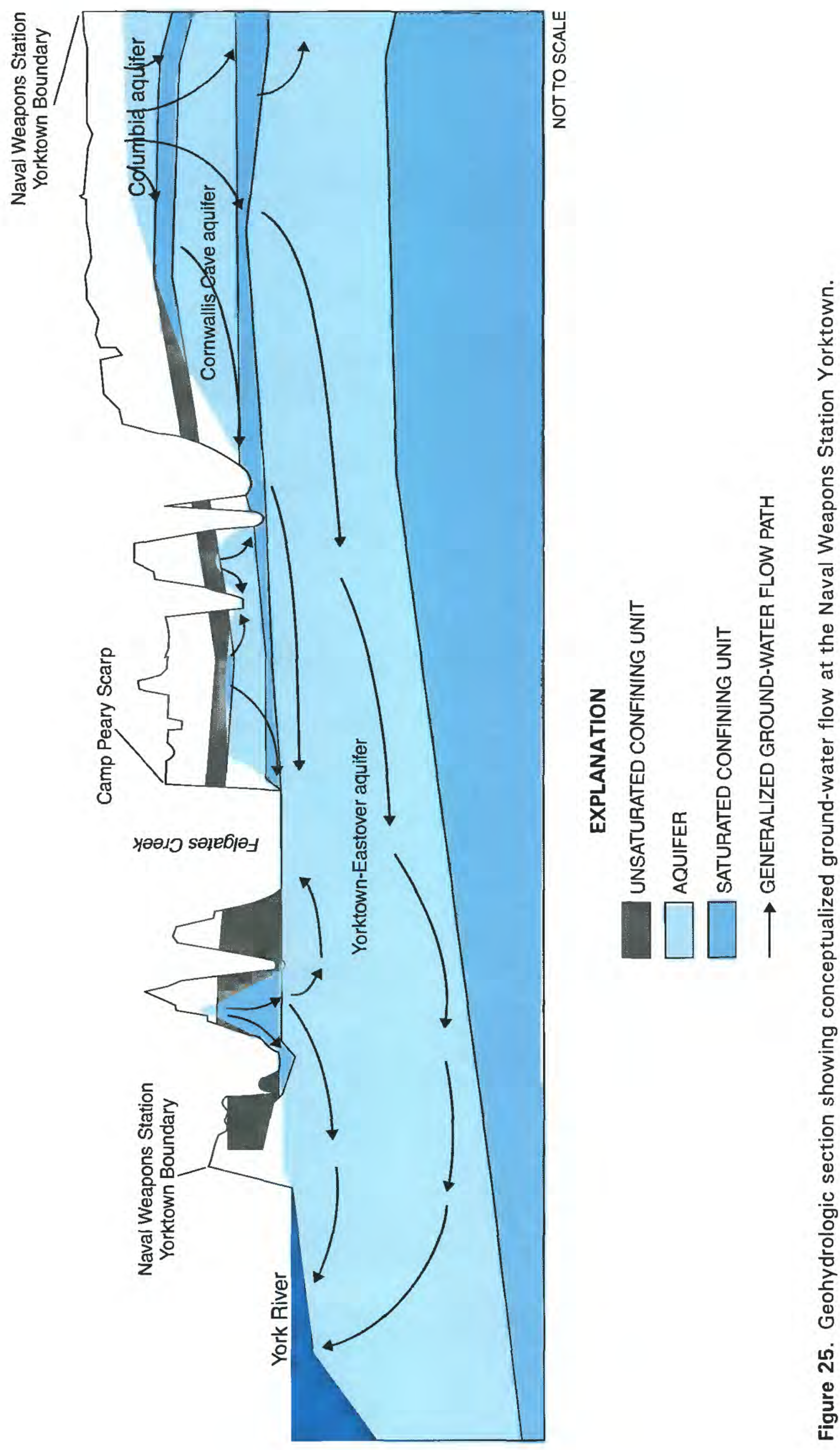


unit and $14 \mathrm{ft}$ for the Yorktown confining unit). Therefore, both confining units are generally leaky. The Cornwallis Cave confining unit at the Station serves as a minimal vertical barrier between the Columbia and underlying Cornwallis Cave aquifers.

Water may temporarily become perched above the Cornwallis Cave confining unit in Columbia sediments beyond the Columbia aquifer limits shown in figures 6 and 7 , but this water rapidly dissipates through evapotranspiration or downward leakage. Water levels in the Columbia aquifer fluctuate vertically (fig. 21) and laterally in response to recharge, evapotranspiration, and downward leakage through the underlying Cornwallis Cave confining unit. Although some lateral ground-water flow in the Columbia aquifer radiates outward from the interior of each pod (fig. 6), the dominant direction of flow is downward through intervening confining units, recharging the underlying Cornwallis Cave and Yorktown-Eastover aquifers. The Columbia aquifer generally does not discharge to springs at the Station.

\section{Cornwallis Cave Aquifer}

The Cornwallis Cave aquifer receives recharge as leakage through the Cornwallis Cave confining unit at elevated areas between stream valleys and adjacent slopes of the Station. This recharge originates either from the Columbia aquifer or from rainfall percolating downward outside the boundaries of the Columbia aquifer. The Cornwallis Cave aquifer generally is confined beneath elevated areas between stream valleys and unconfined along adjacent slopes and in the valleys. Water levels in the unconfined aquifer fluctuate vertically and laterally in response to recharge, evapotranspiration, and downward leakage through the underlying Yorktown confining unit. Ground water flows through the Cornwallis Cave aquifer to discharge directly to seeps, springs, stream valleys, and estuaries. Most of the springs identified at the Station during this study emanate from the Cornwallis Cave aquifer. The lateral component of ground-water flow in the Cornwallis Cave aquifer is directed from elevated interstream areas to the nearby minor or major stream valleys (fig. 11; wells 59F63 and 59F73, table 2). The potentiometric high across the south central part of the Station (fig. 11) divides ground-water flowing toward the York and James Rivers.

Some ground water flows downward through the less permeable Yorktown confining unit into the underlying Yorktown-Eastover aquifer. The Yorktown confining unit generally is less permeable than the Cornwallis Cave confining unit (tables 7 and 5, respectively). The Yorktown confining unit across the Lackey Plain at the Station serves as a more substantial vertical barrier between the Cornwallis Cave and underlying Yorktown-Eastover aquifers than the upper confining unit. The Yorktown confining unit is inferred to be of higher permeability and less of a barrier under the Croaker flat, where sediment reworking during the Pleistocene Epoch may have resulted in increased permeability.

\section{Yorktown-Eastover Aquifer}

The Yorktown-Eastover aquifer receives recharge as leakage through the Yorktown confining unit. This recharge originates from (1) the Cornwallis Cave aquifer across the Lackey Plain at the Station, (2) the Columbia aquifer below the Croaker flat, or (3) rainfall percolating downward outside the Columbia aquifer boundaries at the Croaker flat. The Yorktown-Eastover aquifer is generally confined across most of the Station, but unconfined along part of Felgates Creek and in stream valleys and along adjacent slopes in Croaker flat. The unconfined areas fluctuate vertically and laterally in response to recharge and evapotranspiration. Ground water flows through the Yorktown-Eastover aquifer to discharge directly to stream valleys and estuaries. Because the top crop line of the aquifer is close to sea level, no seeps or springs could be definitely identified as emanating from the Yorktown-Eastover aquifer during field reconnaissance for this study. The lateral component of groundwater flow in the Yorktown-Eastover aquifer follows a pattern similar to the overlying Cornwallis Cave aquifer, except the potentiometric highs in the YorktownEastover aquifer are slightly offset to the south along part of the York-James ground-water divide (figs. 11 and 16). Lateral ground-water flow is from the major potentiometric highs between streams toward the major stream valleys (figs. 16 and 17).

The underlying Eastover-Calvert confining unit effectively isolates the Yorktown-Eastover aquifer from deeper ground-water-flow systems as evidenced by low permeability (table 9) and great thickness (table 2, sections, pl. 1). A small amount of water is able to flow down through the tight, thick Eastover-Calvert confining unit in the Station vicinity (Laczniak and Meng, 1988), but this amount is estimated to be small compared to the total water in the shallow ground-water system. 


\section{STUDY IMPLICATIONS FOR REMEDIATION ACTIVITIES}

The four principal findings of this study are as follows: (1) The shallow aquifer system at the Naval Weapons Station Yorktown is divided into three aquifers and two leaky confining units across the Lackey Plain, but only two shallow aquifers and one leaky confining unit are present under the Croaker flat; (2) the base of the shallow aquifer system is a $150-\mathrm{ft}$ thick, low permeability confining unit ranging in altitude from approximately 40 to $80 \mathrm{ft}$ below sea level-effectively isolating the system from deeper aquifers; (3) ground water flows downward from the Columbia aquifer (recharge area) through the underlying confining unit and then through the Cornwallis Cave and Yorktown-Eastover aquifers toward the stream valleys and estuaries (discharge areas); and (4) a ground-water divide trends west to east across the south central Station from which ground-water flow is either generally north toward the York River estuary or south toward the James River estuary. These findings can be used to design monitor networks on wells and streams, to provide guidance for design depths for remediation of potential ground-water contaminants, to identify general ground-water-flow directions and rates on or off Station property, and to guide the design of numerical groundwater-flow models of the shallow aquifer system at the Station.

Knowledge that ground water at the Station generally flows from elevated areas between stream valleys to adjacent stream valleys and estuaries will be fundamentally useful in siting wells to monitor contamination and background conditions at remediation-study sites and in projecting offsite effects. The number of monitor wells could be optimized by selecting common background (upgradient) well sites for multiple closely spaced remediation sites. By identifying nearby discharge areas, site investigators can supplement downgradient wells with spring or stream sampling sites and reduce site construction costs.

The number, depth, and thicknesses of shallow aquifers, as described on maps and diagrams in this report, can be used to determine well locations, wellscreen lengths, protective casing depths, and the number of wells needed per cluster to discern significant differences in the vertical water-quality profile at a remediation study site. Through an understanding of the geohydrologic framework and careful screen and casing emplacement, short circuiting of the natural vertical ground-water profile from cross screening of multiple aquifers can be avoided. In addition, knowledge of the depth to the nearest underlying confining unit at each remediation study site can be used to design monitoring wells for detecting dense nonaqueous phase liquids that migrate to the bottom of aquifers. If deep contamination is identified, depths to confining units are needed to design the vertical extent of remediation techniques.

The geohydrologic data in this report can be used to estimate the average linear velocity of the ground water with the following equation (modified from Lohman, 1979, p. 10):

$$
\bar{v}=\frac{-K \frac{d h}{d l}}{\theta}
$$

where

$\bar{v}=$ average linear velocity $(\mathrm{L} / \mathrm{T})$,

$K=$ horizontal hydraulic conductivity $(\mathrm{L} / \mathrm{T})$ (see tables 4,6 , and 8 ),

$\frac{d h}{d l}=$ hydraulic gradient, or unit change in water level per unit length of flow (from figs. 6, 11, or 17), and

$\theta=$ effective porosity, as a decimal fraction ( 0.43 for fine grained sand-Todd, 1980 , p. 28).

Information included in this report regarding the direction and rate of ground-water flow across the Station boundaries can assist environmental managers in assessing the potential areal effects from contamination releases occuring on either Station property or adjacent areas. Knowledge of ground-water-flow direction is essential in remediation studies for identifying ambient ground-water quality at the Station as a benchmark for remediation goals at contaminated sites. If a contamination release occurs along one of the heavily used transportation corridors adjacent to the Station, environmental managers also can use the results of this study to determine ground-water-flow rates and flow direction and to identify impacted areas and adverse effects on ambient wells or remediation study sites.

The information in this report can be used to design numerical ground-water-flow models, which yield a more rigorous analysis of ground-water-flow direction and rate than can be achieved using geohydrologic framework data alone. In combination with solute transport modeling, ground-water-flow models can be used to estimate the direction and velocity of plume movement and the potential effectiveness of various remediation strategies (Maidment, 1993). Among a few of the remediation strategies under consideration at the Station that could be evaluated using numerical models are conventional pump-and-treat technologies, bioremediation (intrinsic or active), and long-term monitoring. 


\section{SUMMARY}

In cooperation with the Naval Weapons Station Yorktown the USGS began a study of the shallow aquifer system at the 10,624-acre Station installation in Yorktown, Va., in 1995. This report (1) defines the geohydrologic framework for the shallow aquifer system, (2) determines the hydraulic properties of the geohydrologic units, and (3) presents a conceptualization of the groundwater-flow system.

The shallow aquifer system stratigraphy at the Station consists of nine formally named geologic formations, which range in age from early Miocene to late Pleistocene, and deposits of Holocene age. Older shallow sediments in the vicinity of the Station were deposited on a shallow shelf near the western edge of a deep Eocene bolide impact crater. Younger shallow sediments at the Station were deposited in estuaries and rivers.

The geohydrologic framework of the shallow aquifer system at the Station consists of six units: (1) the Columbia aquifer, (2) the Cornwallis Cave confining unit, (3) the Cornwallis Cave aquifer, (4) the Yorktown confining unit, (5) the Yorktown-Eastover aquifer, and (6) the Eastover-Calvert confining unit as shown in maps and diagrams throughout this report. The Columbia aquifer is unconfined and the Cornwallis Cave and YorktownEastover aquifers are confined in some areas of the Station and unconfined in others. The aquifer sediments predominantly contain quartz in all of the aquifers, and a lesser amount of calcite in the lower two aquifers. Other constituents include illite, glauconite, or mica; pyrite, and lepidocrocite having sparse amounts of other minerals. Kaolinite is conspicuously missing from both the aquifer and confining unit sediments sampled at the Station. Horizontal hydraulic conductivities range from a low of $0.004 \mathrm{ft} / \mathrm{d}$ in the Yorktown-Eastover aquifer to a high of $9 \mathrm{ft} / \mathrm{d}$ in the Cornwallis Cave aquifer. Vertical hydraulic conductivities for sands in all of the aquifers are comparable in range to the upper two confining units, from $1.7 \times 10^{-5} \mathrm{ft} / \mathrm{d}$ in the Yorktown-Eastover aquifer to $4.8 \times 10^{-1} \mathrm{ft} / \mathrm{d}$ in the same aquifer. Pollen analyses and low topographic elevation indicate that the Cornwallis Cave aquifer has been eroded along an unconformity surface and is missing below much of the northeastern part of the Station.

The Cornwallis Cave and Yorktown confining units are thin (generally 8 to $14 \mathrm{ft}$ in thickness), but the Eastover-Calvert confining unit is thick (140 to more than $166 \mathrm{ft}$ in thickness) at the Station. The top of the Eastover-Calvert confining unit (from 40 to less than
$80 \mathrm{ft}$ below sea level) defines the base of the shallowaquifer system. The confining-unit sediments predominantly contain quartz and minor amounts of illite, glauconite, or mica with pyrite. Vertical hydraulic conductivities for the upper two confining units range from a low of $1.3 \times 10^{-5} \mathrm{ft} / \mathrm{d}$ in the Yorktown confining unit to a high of $1.4 \times 10^{-2} \mathrm{ft} / \mathrm{d}$ in the Cornwallis Cave confining unit. The vertical hydraulic conductivities of the Eastover-Calvert confining unit range from $6.0 \times 10^{-6}$ to $4.3 \times 10^{-4} \mathrm{ft} / \mathrm{d}$. The upper two confining units are leaky in comparison to the basal confining unit and have vertical hydraulic conductivities within the range of the vertical hydraulic conductivities of sands in the aquifers.

Two primary geohydrologic settings are present at the Station: (1) Recharge areas, where sediments of the Columbia, Cornwallis Cave, and Yorktown-Eastover aquifers are saturated, and (2) discharge areas where sediments of the Columbia aquifer are unsaturated, but sediments of the Cornwallis Cave and Yorktown-Eastover aquifers are saturated. The Cornwallis Cave aquifer may not be present in either of these settings, where it is missing along an unconformity beneath Croaker flat. In recharge areas water-level fluctuations are generally pronounced, vertical head gradients between aquifers are generally high, and ground-water flow is directed downward. In discharge areas, water-level fluctuations are less pronounced, downward gradients are generally low or may reverse to an upward direction, and ground-water flow is directed toward the discharge areas (seeps, springs, streams, and estuaries).

In the conceptual ground-water-flow system at the Station, ground water flows downward from the Columbia aquifer in the recharge areas to and through the Cornwallis Cave and (or) Yorktown-Eastover aquifers to the discharge areas (seeps, springs, streams, and estuaries). A ground-water divide trends west to east across the south central Station in each of the lower two shallow aquifers. Ground-water flow generally is either north toward the York River estuary or south toward the James River estuary on opposite sides of the divide.

These findings can be used to design monitor well and stream networks, to provide guidance for design depths for remediation of potential ground-water contaminants, and to identify general ground-water-flow directions and rates at the Station and adjacent areas. These results also can be used to design numerical groundwater-flow models of the shallow aquifer system at the Station. 


\section{REFERENCES CITED}

Bailey, A., 1981, Chemical and mineralogical differences between Kittanning coals from marine-influenced versus fluvial sequences: Journal of Sedimentary Petrology, v. 51, p. $383-395$.

Baker Environmental, Inc., 1995, Summary of background constituent concentrations and characterization of the biotic community from the York River drainage basin, Naval Weapons Station, Yorktown, Virginia: Baker Environmental, Inc., Coraopolis, Pa., [variously paged].

Baker Environmental, Inc., and Roy F. Weston, Inc., 1993, Final round one remedial investigation report for sites 1-9, 11, 12, 16-19, and 21, Naval Weapons Station, Yorktown, Virginia: Baker Environmental, Inc., Coraopolis, $\mathrm{Pa}$., [variously paged].

Bick, K.F., and Coch, N.K., 1969, Geology of the Williamsburg, Hog Island, and Bacons Castle quadrangles, Virginia: Virginia Division of Mineral Resources Report of Investigations $18,28 \mathrm{p}$.

Bouwer, Herman, 1989, The Bouwer and Rice slug test-an update: Ground Water, v. 27, no. 3, p. 304-309.

Bouwer, Herman, 1995, Estimating the ability of the vadose zone to transmit liquids, in Wilson, L.G. and others, eds., Handbook of vadose zone characterization and monitoring: Boca Raton, Fla., CRC Press, Inc., p. 177-188.

Brockman, A.R., and Richardson, D.L., 1992, Hydrogeologic framework of the shallow aquifer system of York County, Virginia: U.S. Geological Survey Water-Resources Investigations Report 92-4111, $36 \mathrm{p}$.

C.C. Johnson and Associates, Inc., and CH2M Hill, 1984, Initial assessment of Naval Weapons Station, Yorktown, Va., [variously paged].

Cederstrom, D.J., 1957, Geology and ground-water resources of the York-James Peninsula, Virginia: U.S. Geological Survey Water-Supply Paper 1361, $237 \mathrm{p}$.

Clingan, Susan, 1961, The history of the Naval Weapons Station, Yorktown, Virginia: Yorktown, Va., Naval Weapons Station, $24 \mathrm{p}$.

Colman, S.M., Halka, J.P., Hobbs, C.H., III., Mixon, R.B., and Foster, D.S., 1990, Ancient channels of the Susquehanna River beneath Chesapeake Bay and the Delmarva Peninsula: Geological Society of America Bulletin, v. 102, p. $1268-1279$.

Cooper, H.H., Jr., Bredehoeft, J.D., and Papadopulos, I.S., 1967, Response of a finite-diameter well to an instantaneous charge of water: Water Resources Research, v. 3, no. 1, p. $263-269$.

Dames and Moore, 1986, Confirmation study step IA (Verification), round one, Naval Weapons Station, Yorktown, Va., [variously paged].

Dames and Moore, 1988, Confirmation study step IA (Verification), round two, Naval Weapons Station, Yorktown, Va., [variously paged].
Engineering-Science, Inc., 1994, Supplemental site characterization and ecological assessment report, Commonwealth of Virginia Emergency Fuel Storage Facility, York County, Virginia: Prepared for the Commonwealth of Virginia Department of Emergency Services and the U.S. Environmental Protection Agency Region III [variously paged].

Fetter, C.W., 1994, Applied hydrogeology (3d ed.): New York, N.Y., Macmillan College Publishing Co., 691 p.

Foote, Shelby, 1986, The Civil War, a narrative (v. 1): New York, N.Y., Vintage Books, 840 p.

Freeze, R.A., and Cherry, J.A., 1979, Groundwater: Englewood Cliffs, N.J., Prentice-Hall, 604 p.

Guymon, G.L., 1994, Unsaturated zone hydrology: Englewood Cliffs, N.J., Prentice-Hall, 210 p.

Hack, J.T., 1957, Submerged river system of Chesapeake Bay: Bulletin of the Geological Society of America, v. 68, p. 817-830.

Hagemann, J.A., 1988, The heritage of Virginia: the story of place names in the Old Dominion ( $2 \mathrm{~d}$ ed.): West Chester, Pa., Whitford Press, $297 \mathrm{p}$.

Heath, R.C., 1983, Basic ground-water hydrology: U.S. Geological Survey Water-Supply Paper 2220, 84 p.

Hurlbut, C.S., Jr., and Klein, Cornelis, 1977, Manual of mineralogy (19th ed.): New York, N.Y., John Wiley and Sons, Inc., $532 \mathrm{p}$.

Johnson, G.H., 1972, Geology of the Yorktown, Poquoson West, and Poquoson East quadrangles, Virginia: Virginia Division of Mineral Resources Report of Investigations $30,57 \mathrm{p}$.

Johnson, G.H., Beach, Todd, Harris, M.S., and Herman, Julie, 1993, Late Cenozoic environments along the James River of southeastern Virginia: College of William and Mary, Virginia Field Conference, 1993, Guidebook, 36 p.

Johnson, G.H., Berquist, C.R., Jr., Ramsey, Kelvin, and Peebles, P.C., 1982, Guidebook to the late Cenozoic geology of the lower York-James Peninsula, Virginia: Williamsburg, Va., College of William and Mary, Department of Geology, Guidebook No. 3, 58 p.

Johnson, G.H., Peebles, P.C., Otte, L.J., and Smith, B.J. 1985, The late Cenozoic geology of southeastern Virginia and the Great Dismal Swamp: Williamsburg, Va., guidebook prepared for the Eastern Section American Association of Petroleum Geologists field trip no. 1, 68 p.

Johnson, G.H., Ward, L.W., and Peebles, P.C., 1987, Stratigraphy and paleontology of Pliocene and Pleistocene deposits of southeastern Virginia, in Geological excursions in Virginia and North Carolina: Geological Society of America, Southeastern Section, 36th Annual Meeting, 1987, Guidebook, Field Trips nos. 1-7, p. 189-218.

Kull, T.K. and Laczniak, R.J., 1987, Ground-water withdrawals from the confined aquifers in the Coastal Plain of Virginia, 1891-1983: U.S. Geological Survey WaterResources Investigations Report 87-4049, 37 p. 
Laczniak, R.J., and Meng, A.A., III, 1988, Ground-water resources of the York-James Peninsula of Virginia: U.S. Geological Survey Water-Resources Investigations Report 88-4059, $178 \mathrm{p}$.

Lohman, S.W., 1979, Ground water hydraulics: U.S. Geological Survey Professional Paper 708, 70 p.

Maidment, D.R., 1993, Handbook of hydrology: New York, NY, McGraw-Hill, Inc., [variously paged].

Meng, A.A., III, and Harsh, J.F., 1988, Hydrogeologic framework of the Virginia Coastal Plain: U.S. Geological Survey Professional Paper 1404-C, $82 \mathrm{p}$.

Mixon, R.B., Berquist, C.R., Jr., Newell, W.L., Johnson, G.H., Powars, D.S., Schindler, J.S., and Rader, E.K., 1989, Geologic map and generalized cross sections of the Coastal Plain and adjacent parts of the Piedmont, Virginia: U.S. Geological Survey Miscellaneous Investigations Series Map I-2033, 2 sheets, scale 1:250,000.

Mitchell, J.B., 1962, Decisive battles of the American Revolution: Greenwich, Conn., Fawcett Publications, Inc., 224 p.

Naval Weapons Station, 1993, Proud of our past, focused on the future: Yorktown, Va., Naval Weapons Station 75th anniversary publication, $7 \mathrm{p}$.

Poag, C.W., 1997, The Chesapeake Bay bolide impact: A convulsive event in Atlantic Coastal Plain evolution: Sedimentary Geology, v. 108, p. 45-90.

Poag, C.W., Powars, D.S., Poppe, L.J., and Mixon, R.B., 1994, Meteoroid mayhem in ole Virginny: source of the North American tektite strewn field: Geology, v. 22, p. 691-694.
Staub, J.R., and Cohen, A.D., 1978, Kaolinite-enrichment beneath coals; a modern analog, Snuggedy Swamp, South Carolina: Journal of Sedimentary Petrology, v. 38, p. 97-135.

Todd, D.K., 1980, Groundwater hydrology (2d ed.): New York, N.Y., John Wiley and Sons, 535 p.

U.S. Environmental Protection Agency Region III, Commonwealth of Virginia, and the U.S. Department of the Navy, 1994, U.S. Department of the Navy, Naval Weapons Station-Yorktown, Yorktown, Virginia, Federal Facility Agreement under CERCLA Section 120: Administrative Docket Number: III-FCA-CERC-009, $72 \mathrm{p}$.

Virginia State Water Control Board, 1973, Ground water of the York-James Peninsula, Virginia: Basic Data Bulletin 39, $74 \mathrm{p}$.

Ward, L.W., 1984, Stratigraphy of outcropping Tertiary beds along the Pamunkey River - Central Virginia Coastal Plain, in Ward, L.W., and Kraft, Kathleen, eds., Stratigraphy and paleontology of the outcropping Tertiary beds in the Pamunkey River region, central Virginia Coastal Plain-Guidebook for Atlantic Coastal Plain Geological Association 1984 field trip: Atlantic Coastal Plain Geological Association, p. 11-78.

Ward, L.W., and Blackwelder, B.W., 1980, Stratigraphic revision of upper Miocene and lower Pliocene beds of the Chesapeake Group, middle Atlantic Coastal Plain: U.S. Geological Survey Bulletin 1482-D, 71 p. 
48 
TABLES $1-2$ 


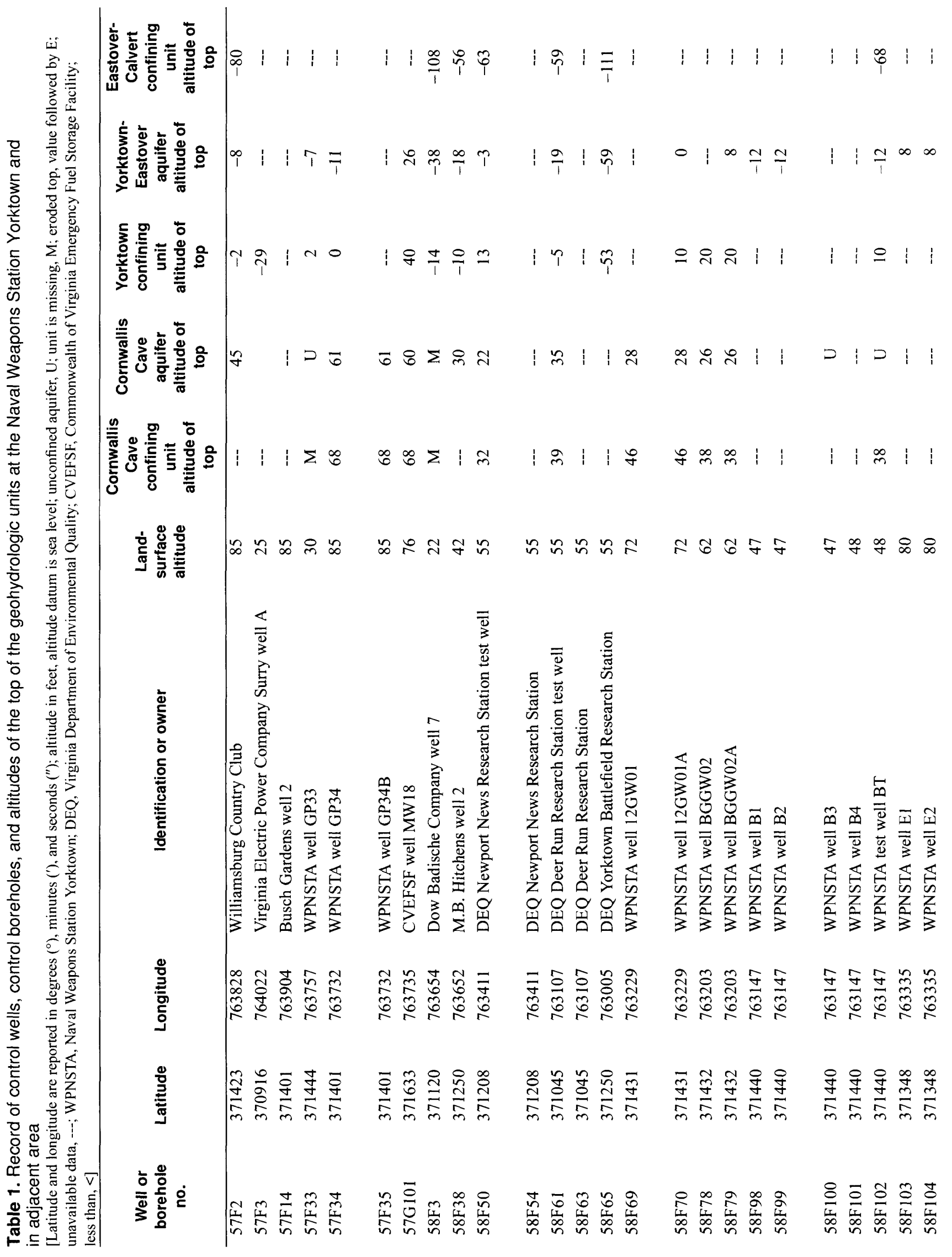




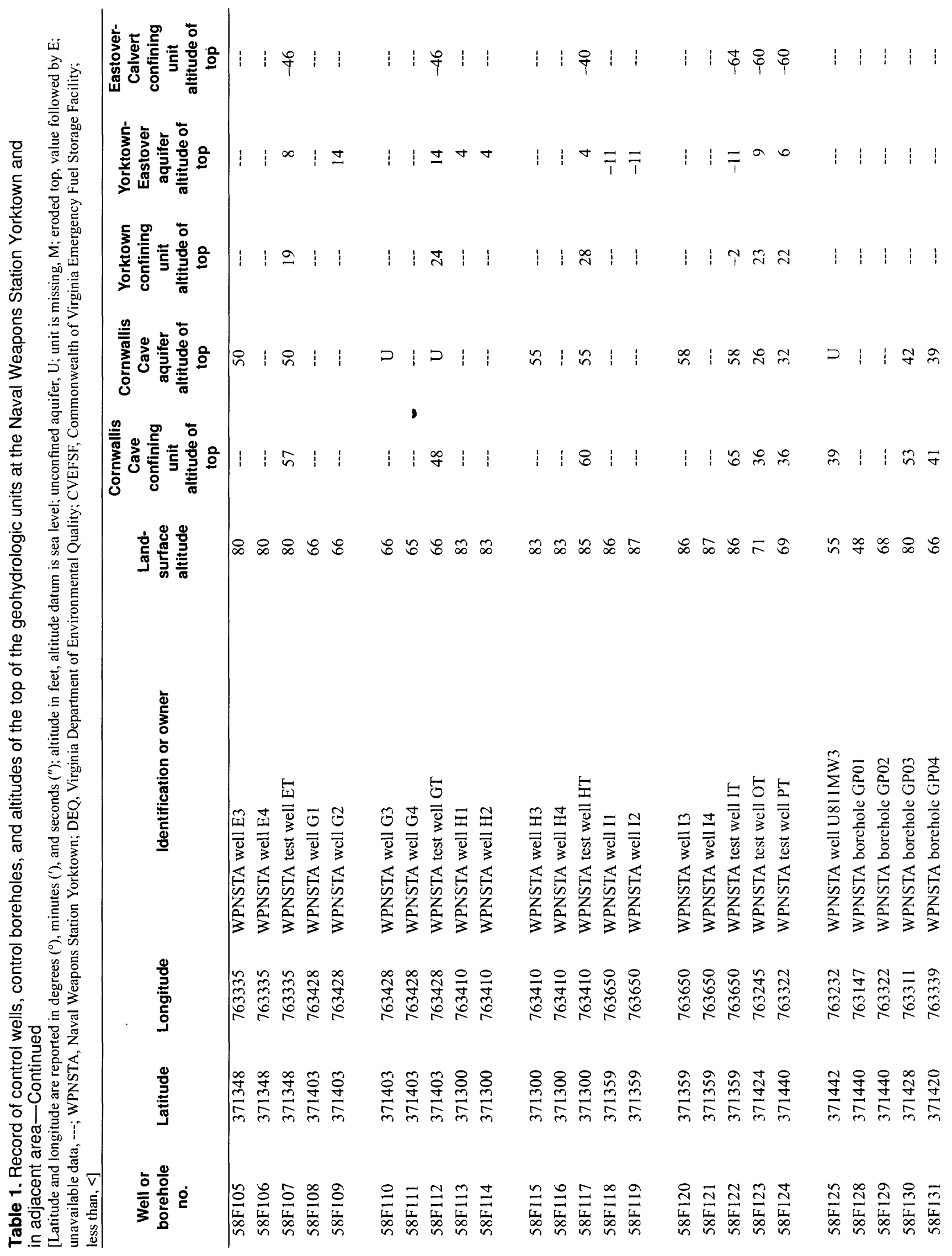




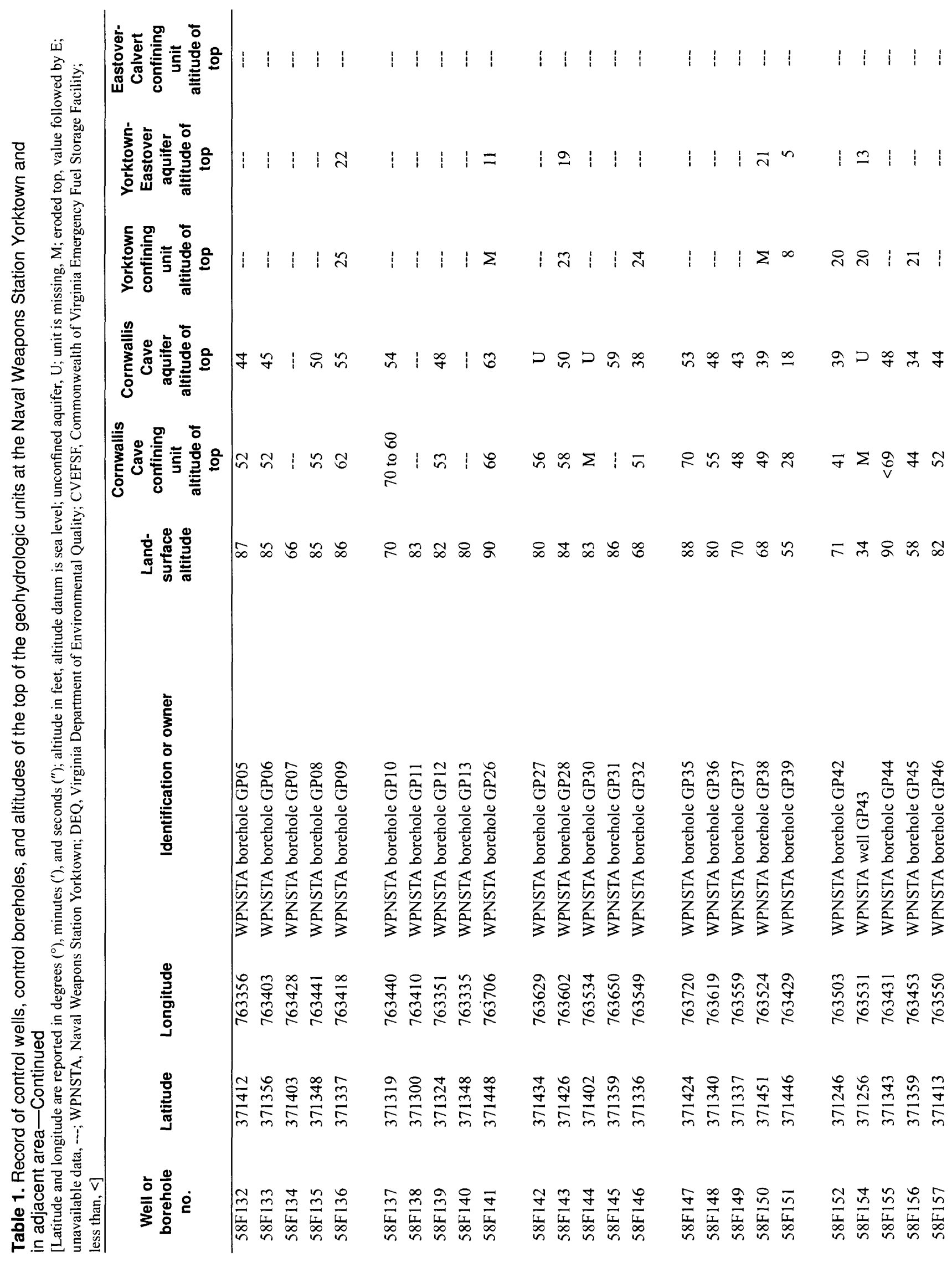




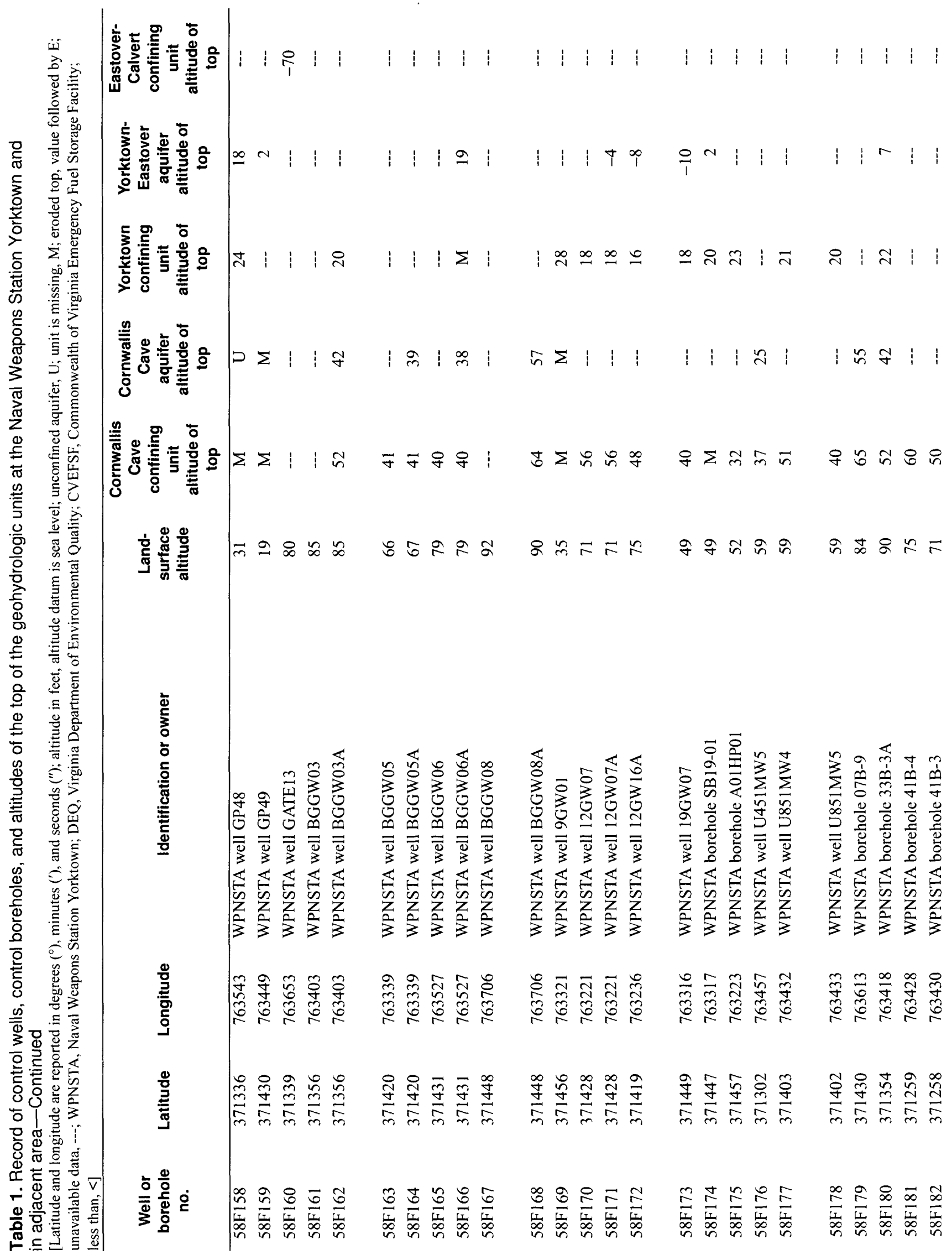




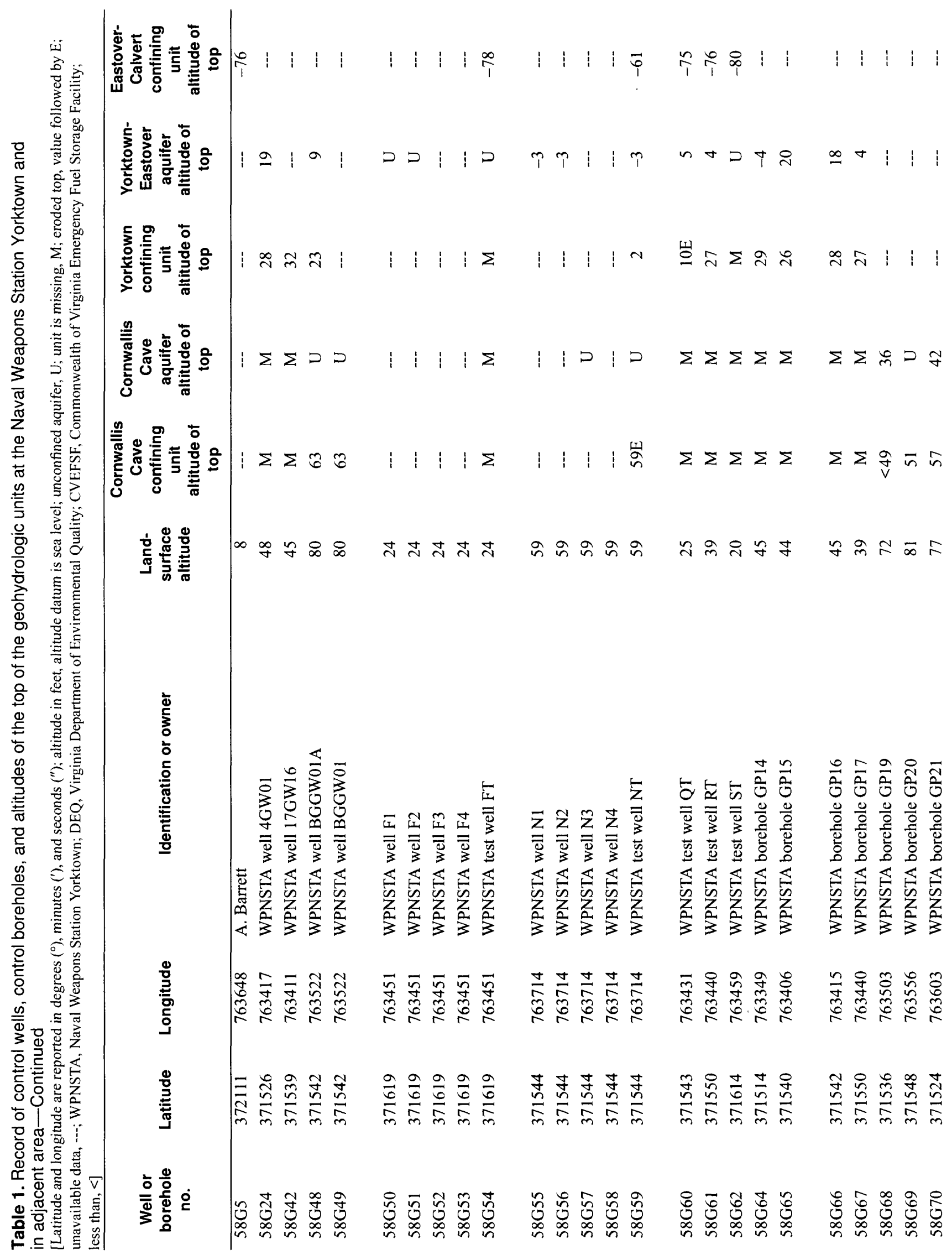




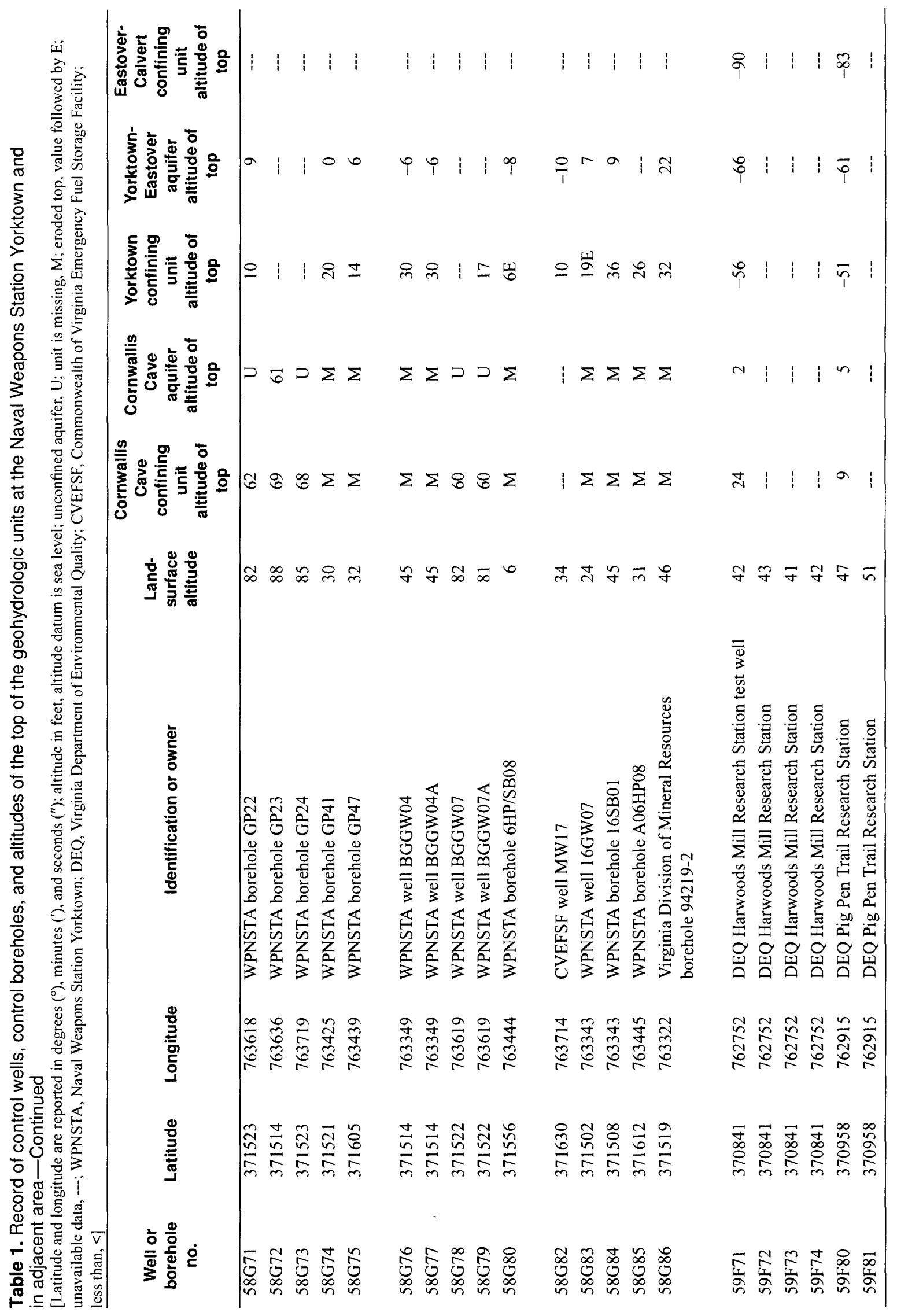




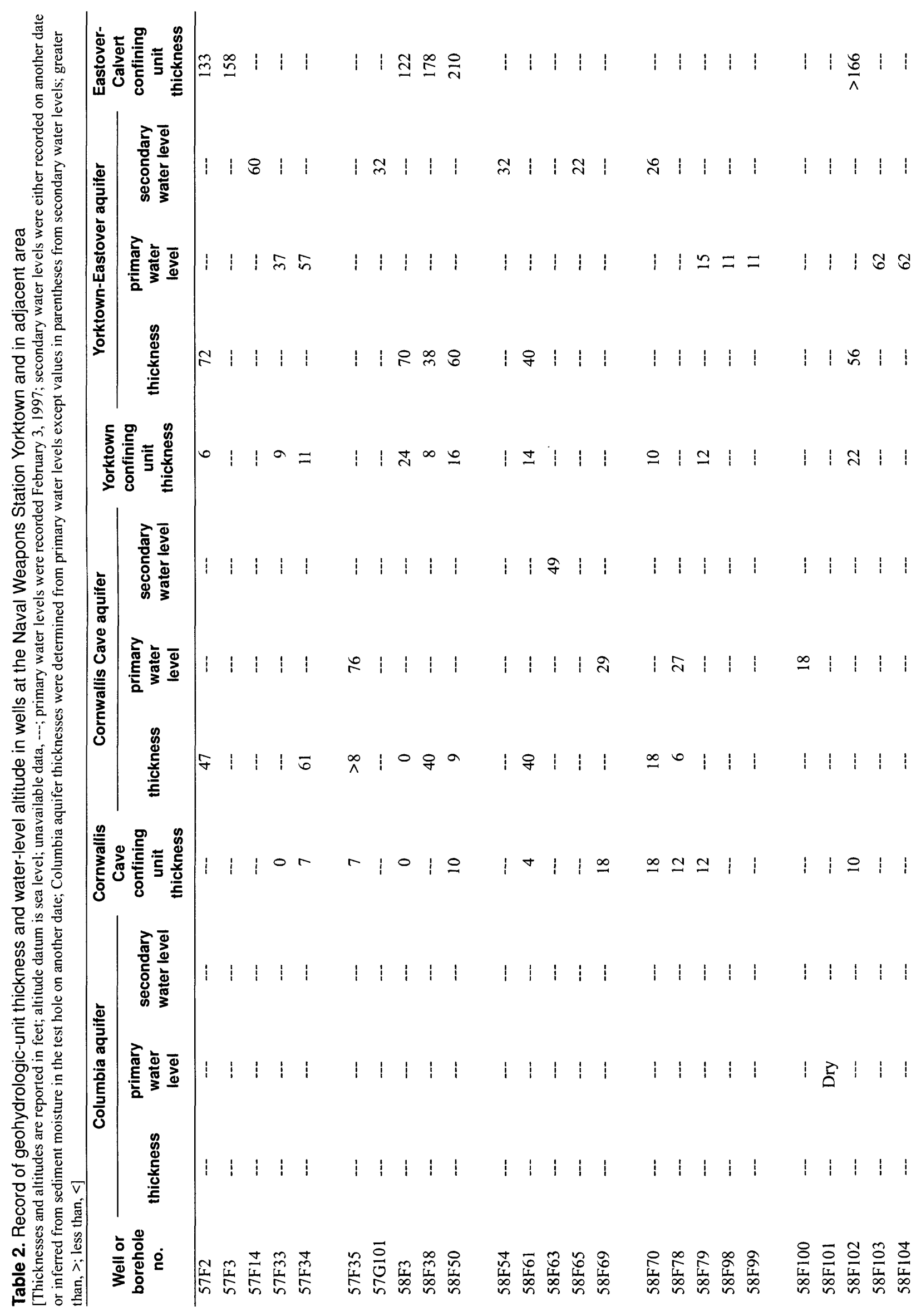




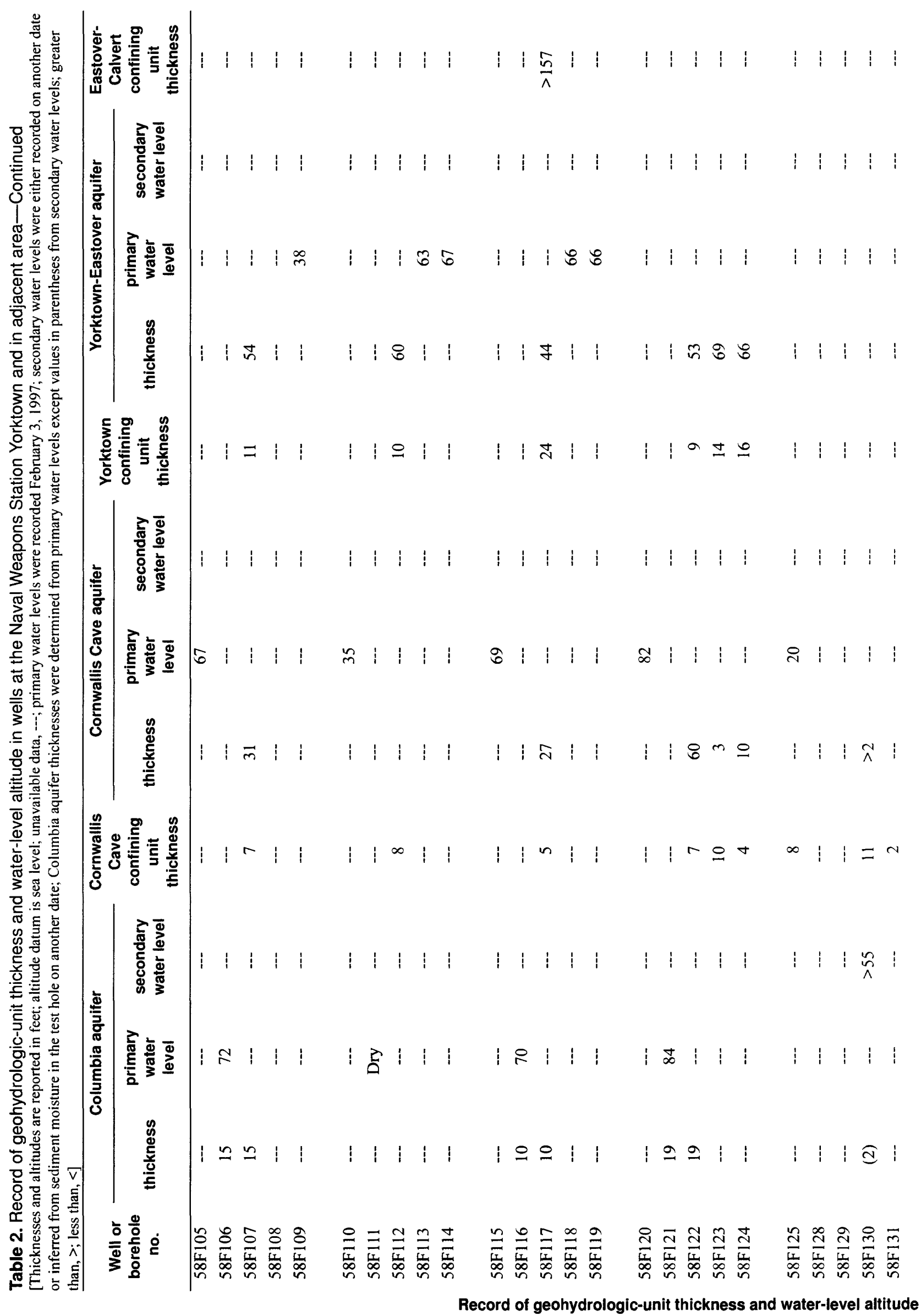




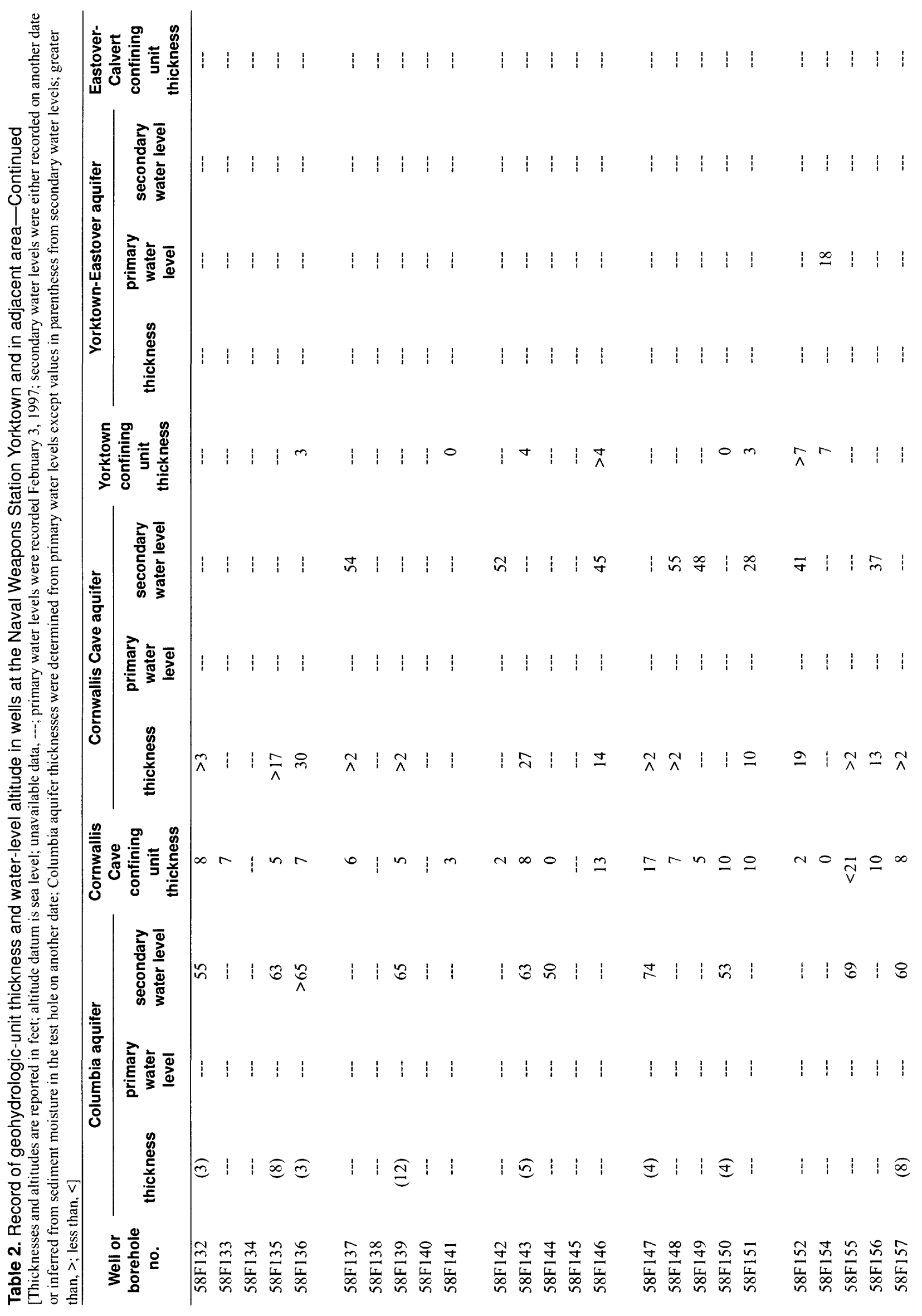




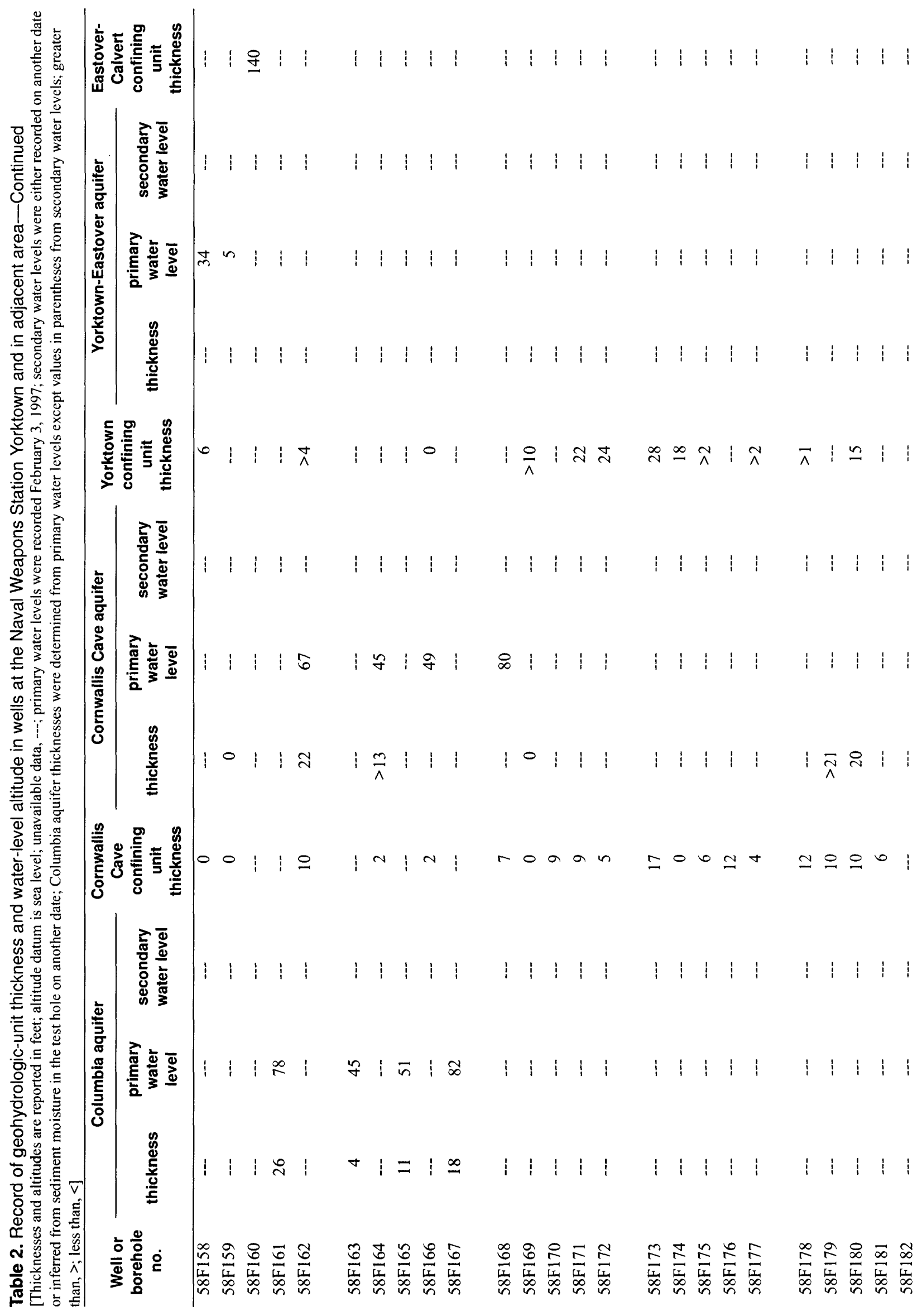




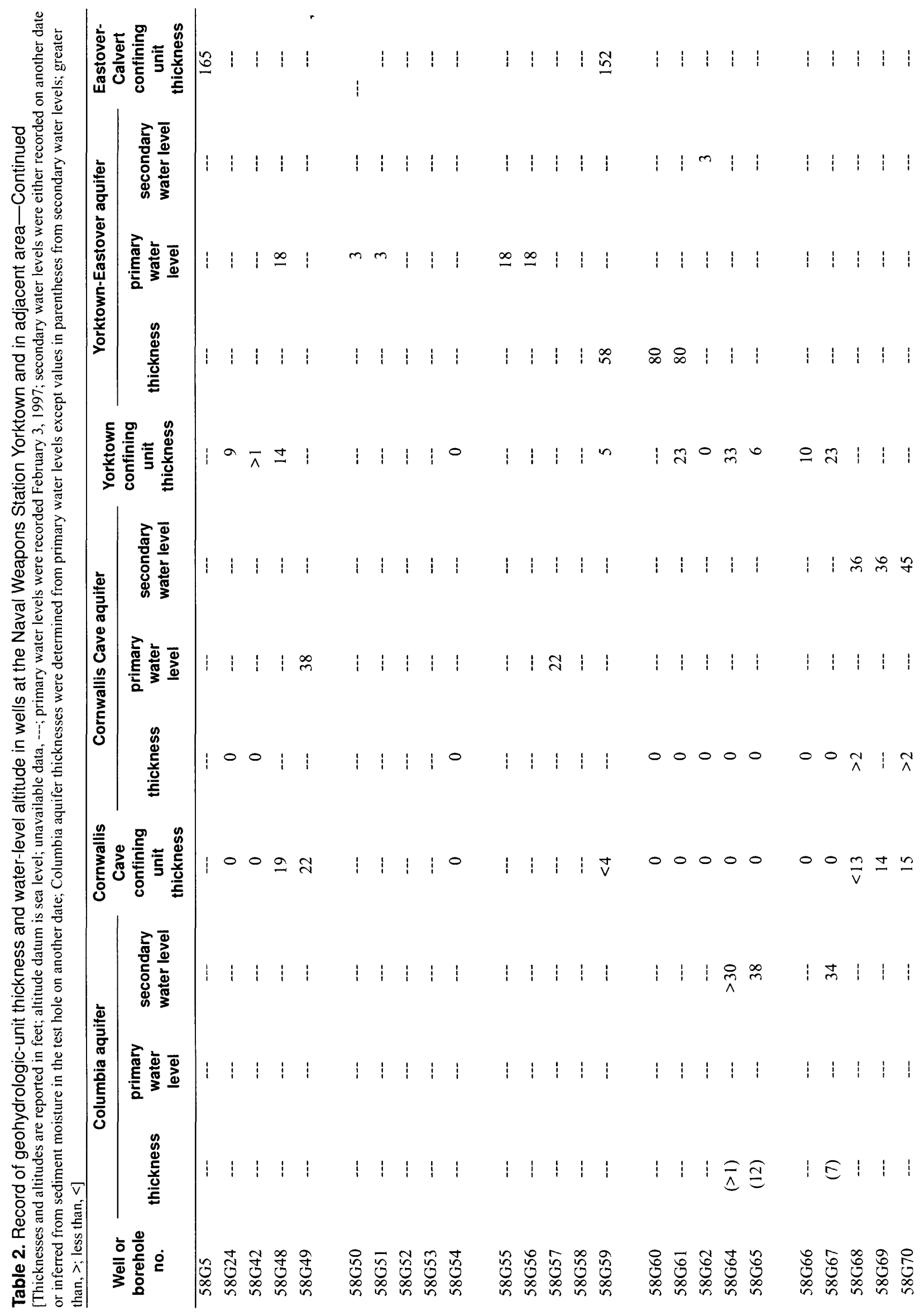

60 Geohydrologic Framework of the Shallow Aquifer System, Naval Weapons Station Yorktown, Yorktown, Virginia 


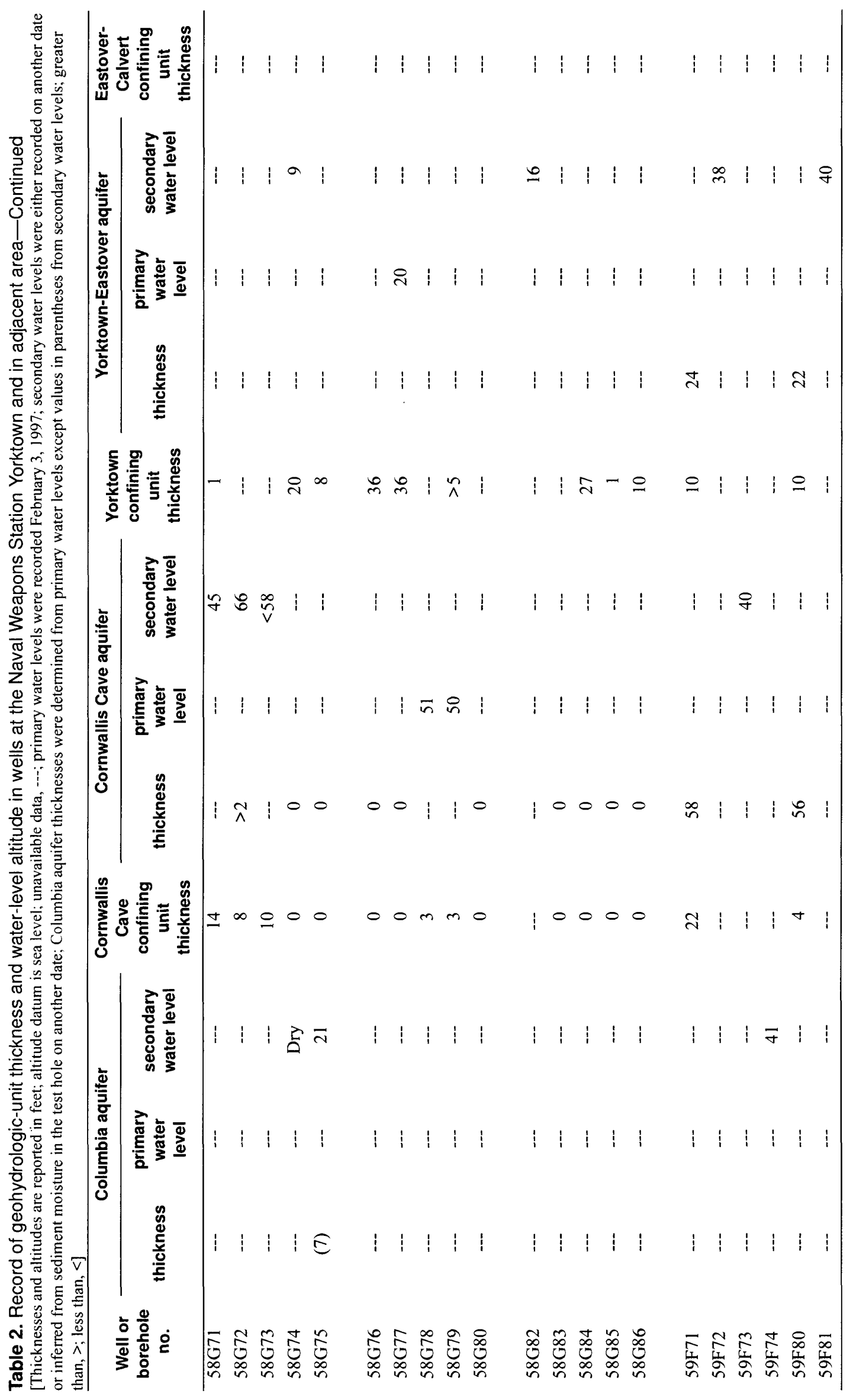

